\author{
UNIVERSIDADE DE SÃO PAULO \\ Programa Interunidades de Pós-Graduação em Energia \\ PIPGE \\ (EP / FEA / IEE / IF)
}

\title{
GESTÃO DE BACIAS AÉREAS COMO INSTRUMENTO DE GESTÃO AMBIENTAL: estudo de caso em projetos de geração de energia no Estado de São Paulo.
}

FABIO FERREIRA FERLING

São Paulo

2008 
FABIO FERREIRA FERLING

\section{GESTÃO DE BACIAS AÉREAS COMO INSTRUMENTO DE GESTÃO AMBIENTAL: estudo de caso em projetos de geração de energia no Estado de São Paulo.}

Dissertação apresentada ao Programa Interunidades de Pós-Graduação em Energia da Universidade de São Paulo (Escola Politécnica / Faculdade de Economia e Administração / Instituto de Eletrotécnica e Energia / Instituto de Física) para obtenção do título de Mestre em Energia.

Orientação: Prof. Dr. Célio Bermann

São Paulo

2008 


\section{AUTORIZO A REPRODUÇÃO E DIVULGAÇÃO TOTAL OU PARCIAL DESTE TRABALHO, POR QUALQUER MEIO CONVENCIONAL OU ELETRÔNICO, PARA FINS DE ESTUDO E PESQUISA, DESDE QUE CITADA A FONTE.}

\section{FICHA CATALOGRÁFICA}

Ferling, Fabio Ferreira.

Gestão de bacias aéreas como instrumento de gestão ambiental: estudo de caso em projetos de geração de energia no Estado de São Paulo / Fabio Ferreira Ferling; orientador Célio Bermann - São Paulo, 2008.

127 p.: il.; $30 \mathrm{~cm}$.

Dissertação (Mestrado - Programa Interunidades de Pós-Graduação em Energia) - EP / FEA / IEE / IF da Universidade de São Paulo.

1.Política ambiental - bacias aéreas 2.Gestão ambiental 3.Poluição atmosférica 4.Geração de energia I. Título. 
UNIVERSIDADE DE SÃO PAULO

PROGRAMA INTERUNIDADES DE PÓS-GRADUAÇÃO EM ENERGIA

EP - FEA - IEE - IF

\section{FABIO FERREIRA FERLING}

"Gestão de bacias aéreas como instrumento de gestão ambiental: estudo de caso em projetos de geração de energia no Estado de São Paulo"

Dissertação defendida e aprovada em 28/04/2008 pela Comissão Julgadora:

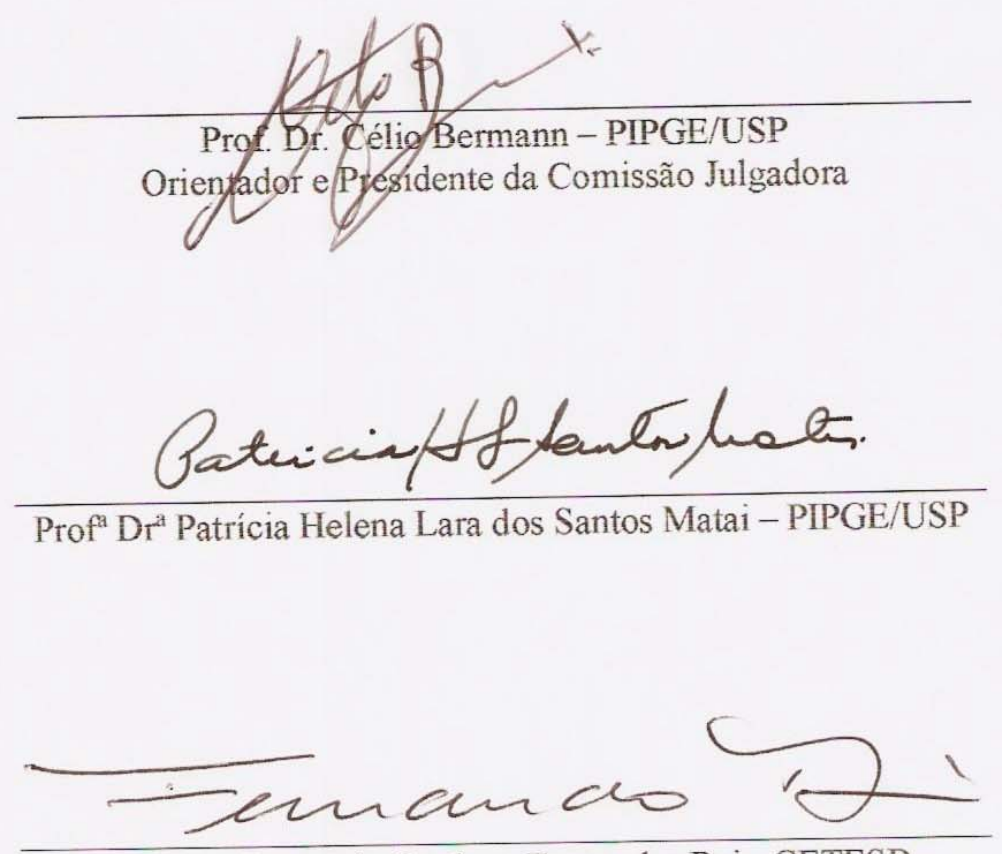

Prof. Dr. Fernando Cardozo Fernandes Rei - CETESB 
Dedico esta obra à minha família: meus PAIS (Walter e Leila), Cláudia, Viviane e à Kátia. Também a todos aqueles que, de alguma forma contribuíram para a realização deste trabalho. 
Agradecimentos:

- aos meus PAIS e todos meus familiares pela paciência e compreensão;

- ao meu orientador Célio Bermann, pelo incentivo na melhoria do meu conhecimento;

- à minha banca; Fernando Cardozo Fernandes Rei e Suani Teixeira Coelho pela orientação na direção do caminho correto;

- aos companheiros da CETESB: Eng.(os) Otávio Okano e Manuel Cláudio de Souza, por estimularem a capacitação de seus companheiros de trabalho e em outros temas de interesse da Companhia e do Meio Ambiente, além de especial menção à Júlio César Dornelas, Marcelo de Souza Minelli, Carlos Komatsu, João Wagner Alves, Ricardo Anazia, Lígia Siqueira, Olímpio de Melo Alves Jr., Cláudio Darwin Alonso, Benedito da Conceição Filho (Benê), Elizabeth Marques e outros que, colaboraram com o enriquecimento e qualidade técnica deste trabalho;

- aos amigos da SMA: Germano Seara Filho, Newton Custódio Dias, Sônia Regina Pita Baccarelli e Julia Yuriko Saito pela colaboração e companherismo;

- ao professores do PIPGE/USP pelos ensinamentos e busca da visão crítica peculiar da universidade e de extrema importância para o avanço das questões de energia e de meio ambiente;

- ao Eng. José Antônio Selegatto (USA), pela visita e informações importantes para validação da hipótese levantada;

- a todos que direta ou indiretamente colaboraram para que a minha participação neste curso fosse possível. 
"A mente que se abre a uma nova idéia jamais voltará ao seu tamanho original."

Albert Einstein 


\section{RESUMO}

Gestão de Bacias Aéreas como Instrumento de Gestão Ambiental para o Desenvolvimento é um trabalho que apresenta uma nova forma com que o Estado de São Paulo visa enfrentar as questões ambientais. A introdução da Gestão Ambiental através de instrumentos de co-regulação e gradação de metas em substituição aos mecanismos tradicionais de comando e controle, notadamente nas ações de fiscalização e licenciamento.

Os motivos que levaram à revisão e às justificativas para as alterações realizadas na legislação ambiental no Estado (Decreto Estadual n ${ }^{\circ}$ 8.468/76) são apresentados, assim como os conceitos ambientais que as fundamentam são pontuados neste trabalho.

Discutem-se também os reflexos da adoção de tal procedimento nos setores envolvidos institucional, industrial e sociedade - e também a aplicação destes junto ao setor de energia, com o estudo realizado em uma usina de açúcar e álcool e em uma usina termelétrica à gás.

As considerações acerca das alterações em curso no sistema de licenciamento ambiental (Decretos Estaduais $n^{\circ} 48.523 / 04, n^{\circ} 50.753 / 06$ e n52.469/07) são apresentadas, mostrando os impactos nos empreendimentos geradores de energia no Estado (nas bacias aéreas saturadas e em vias de saturação).

A utilização da prática de geração de créditos para reduções de emissão de poluentes atmosféricos e o desenvolvimento de um Mercado para a comercialização destes créditos é apresentada como mecanismo de gestão como forma de atendimento aos padrões de qualidade do ar no Estado.

Tratam-se de alterações inovadoras e indutoras de desenvolvimento ao Estado, trazendo benefífios à qualidade ambiental, com a utilização da gestão através de bacias aéreas e o comércio de créditos por redução de emissão de poluentes regulamentados.

Palavras chave: Política-Gestão Ambiental /Poluição atmosférica/Geração de energia 


\begin{abstract}
Air Basins Management as an Environmental Management Implement for Development shows the new way that the Sao Paulo's State aims to tackle environmental issues. The introduction of Environmental Management through instruments of co-regulation and goals gradation, especially supervision and licensing, to the substitution of the traditional mechanisms of command and control.
\end{abstract}

The reasons that led to the revision and the reasons for the changes made in environmental legislation of the State (State Decree $n^{\circ} 8.468 / 76$ ) are presented, as well as the environmental concepts that are presented based on this work.

It discusses also the reflection of adoption of this procedure in the sectors involved institutional, industrial and society - and also the application of these next to the sector of energy, with the study conducted in a plant of sugar and alcohol and a termelectric gas plant.

Considerations about changes underway in environmental licensing system (Decrees State $\mathrm{n}^{\circ} 48.523 / 04, \mathrm{n}^{\circ} 50,753 / 06$ and $\mathrm{n}^{\circ} 52.469 / 07$ ) are presented showing the impacts of energy generating ventures in the State (in saturated air basins and in the process of saturation).

The use of the practice of generating credits for reductions in emission of air pollutants and the development of a market for the marketing of these claims is presented as a mechanism of management as a way to care for patterns of air quality in the State.

These are innovative changes and leading development of the state bringing benefits to the environmental quality, with the use of management through air basins and trade credits for emission reduction of pollutants regulated.

Keywords: Environmental Managements-Policies/Air Pollution / Power Generation 


\section{Lista de ilustrações - figuras e gráficos}

Figura 2.1- Variação de composição e temperatura da atmosfera em função da altura da superfície terreste.

Figura 2.2- Distribuição vertical típica da concentração dos constituintes químicos da atmosfera....

Figura 2.3- Variação da pressão atmosférica e vento superficial (Janeiro a Julho)...........................

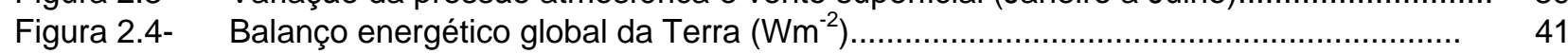

Figura 2.5- Diagrama esquemático dos principais processos químicos e fotoquímicos que afetam a

Figura 2.6- $\quad$ Espectro da radiação solar no topo da atmosfera e ao nível do mar. As áreas rachuradas indicam a absorção feita pelas moléculas.

Figura 2.7 - Diagrama sistemático ilustrativo das regras de reações fotoquímicas do $\mathrm{O}_{3}, \mathrm{OH}, \mathrm{HO}_{2} \mathrm{e}$

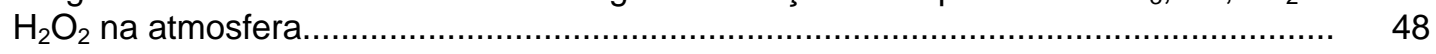

Figura 2.8- Equilíbrio foto-estacionário do ozônio troposférico.................................................... 49

Figura 2.9- Relação entre a intensidade da emissão de $\mathrm{NO}_{x}, \mathrm{COV}(\mathrm{NMHC})$ e concentração máxima de ozônio na região de Kanto-Japão 1981

Figura 2.10- Estabilidade de resistência e de elasticidade. Efeitos de uma perturbação em um ecossistema. A área denominada ET é uma medida relativa da estabilidade total......... 54

Figura 4.1- Situação de saturação dos municípios do Estado de São Paulo..................................... 68

Figura 4.2- Esquema de operacionalização do Decreto Estadual $n^{\circ}$ 50.753/06 e suas alterações.... 70

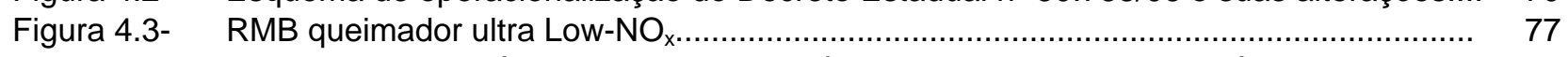

Figura 5.1- Diagrama esquemático do ciclo termodinâmico de uma central termelétrica.................. 87

Figura 5.2- Entorno da UTE Capuava Cogeração.................................................................. 88

Figura 5.3- Evolução das concentrações médias anuais das máximas diárias - RMSP (médias de 1 hora)

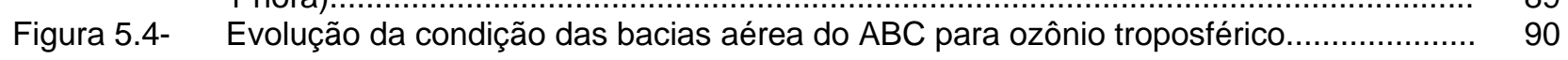

Figura 5.5- $\quad$ Fluxograma simplificado de uma unidade de fabricação de álcool.................................. 95

Figura 5.6- Reprodução de imagem animada da região de Sertãozinho e Ribeirão Preto................. 97

Figura 5.7- Evolução da condição da bacia aérea de Ribeirão Preto para ozônio troposférico............ 98 


\section{Lista de tabelas}

Tabela 2.1- Histórico dos principais episódios críticos de poluição do ar.

Tabela 2.2- Evolução da poluição em nível global dos principais poluentes amostrados pelo GEMS entre período de 1973 a 1985

Tabela 2.3- Estatística descritiva dos níveis de poluição, variáveis meteorológicas e das internações de idosos e crianças, São Paulo, Brasil, 1996-2000.

Tabela 2.4- Riscos relativos (RR) e intervalo de confiança de 95\% (IC95\%) de internações por doenças em crianças para um incremento de $10 \mathrm{mg} / \mathrm{m} 3$ nos níveis de $\mathrm{PM}_{10}, \mathrm{SO}_{2}, \mathrm{NO}_{2}$ e $\mathrm{O}_{3}$ e de 1ppm para o CO. São Paulo, Brasil, 1996-2000.

Tabela 2.5- Níveis máximos de poluentes recomendados pela Organização Mundial da Saúde, para a saúde, exceto câncer e alteração do bem estar.

Tabela 2.6- Níveis de concentração de poluentes e efeitos à saúde pública.

Tabela 2.7- Resumo da monetarização anual das deseconomias (milhões de reais)......

Tabela 2.8- Fontes, características e efeitos dos principais poluentes da atmosfera............

Tabela 2.9- Composição do ar troposférico limpo (não urbano).

Tabela 4.1- Limites de emissão segundo o regime de operação da fonte...

Tabela 4.2- Principais técnicas de controle e redução do $\mathrm{NO}_{x}$......

Tabela 4.3- Empreendimentos licenciados no Estado de São Paulo e consumo de combustível.......

Tabela 4.4- Principais geradores de energia no Estado de São Paulo e emissão de precursores de ozônio troposférico.

Tabela 5.1- Características das fontes emissoras de poluentes atmosféricos.

Tabela 5.6- Geração de créditos de reduções de poluentes atmosféricos na UAA Santo 


\section{Lista de abreviaturas e siglas}

ANEEL - Agência Nacional de Energia Elétrica

ARB - Air Resourses Board (Califórnia Air Protection Agency)

BAT - Best Available Technology

CEAR's - Créditos de Emissões Atmosféricas Reduzidas

CETESB - Companhia de Tecnologia de Saneamento Ambiental do Estado de São Paulo

CO - Monóxido de Carbono

CONSEMA - Conselho Estadual de Meio Ambiente do Estado de São Paulo

COVs não- $\mathrm{CH}_{4}$ - Compostos Orgânicos Voláteis, exceto metano

DMS - Dimetilsulfeto

DPOC - Doença Pulmonar Obstrutiva Crônica

ECP - Equipamento de Controle e Proteção

EIA - Estudo de Impacto Ambiental

EPA- Environmental Protection Agency dos EUA

EPP - Empresas de Pequeno Porte

EVS - Sub-bacia Em Via de Saturação

GEMS - Global Environment Monitoring System

$\mathrm{HO}_{2}$ - Peroxila

$h v$ - hight violet: Comprimento de Onda (radiação)

IPVA - Imposto sobre Propriedade de Veículos Automotores

IVAS - Infecções de Vias Aéreas Superiores

Md - Densidade Molecular

ME - Micro Empresas

MP - Material Particulado

MPEA - Mercado Paulista de Emissões Atmosféricas

MTPD - Melhor Tecnologia Prática Disponível

$\mathrm{NO}_{\mathrm{x}}$ - Óxidos de Nitrogênio $\left(\mathrm{NO}, \mathrm{NO}_{2}, \mathrm{~N}_{2} \mathrm{O}, \mathrm{N}_{2} \mathrm{O}_{4}\right)$; $\left[\mathrm{NO}_{\mathrm{y}}=\mathrm{N}_{\mathrm{x}} \mathrm{O}_{5}, \mathrm{HNO}_{3}, \mathrm{PAN}, \mathrm{NO}_{\mathrm{x}}\right]$

$\mathrm{O}^{*}$ - Odd Oxigen

$\mathrm{O}_{3}$ - Ozônio

OMS - Organização Mundial da Saúde

ONGs - Organizações Não Governamentais

PAN - Peroxiacetil Nitrato 
PI - Partículas finas e Inaláveis

PIV - Programa de Inspeção Veicular

PNUMA - Programa das Nações Unidas para o Meio Ambiente

PQAr - Padrões de Qualidade do Ar

PQU - Petroquímica União

PREA - Programa de Redução de Emissões Atmosféricas

RECLAIM - Regional Clean Air Incentives Market

REDPANARE - Rede Panamericana de Amostragem de Contaminantes Atmosféricos

RIMA - Relatório de Impacto Ambiental

RMSP - Região Metropolitana de São Paulo

SAT - Sub-bacia Saturada

SBPC - Sociedade Brasileira para o Progresso da Ciência

SMA - Secretaria de Estado do Meio Ambiente de São Paulo

$\mathrm{SO}_{\mathrm{x}}$ - Óxidos de Enxofre

UAA - Usina de Açúcar e Álcool

UBC - Usinas de Biocombustíveis

UTE - Usina Termoelétrica

VIGIAR - Programa de Vigilância dos Efeitos na Saúde Relacionados à Poluição do Ar ZEE - Zoneamento Ecológico-Econômico 


\section{SUMÁRIO}

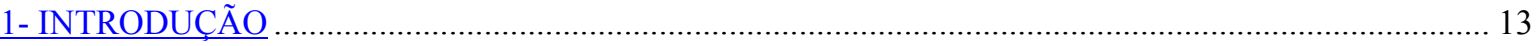

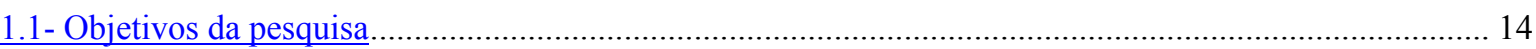

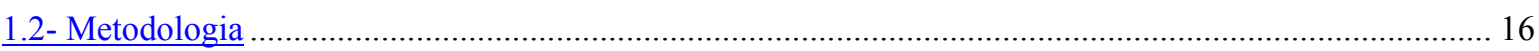

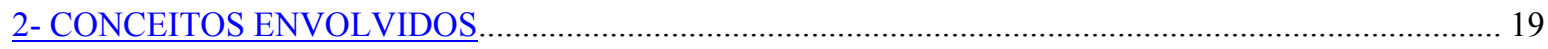

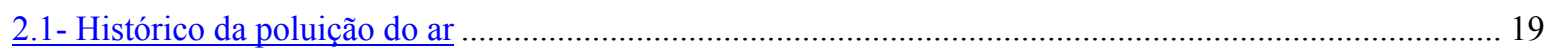

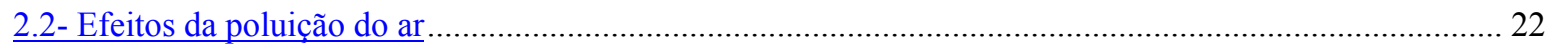

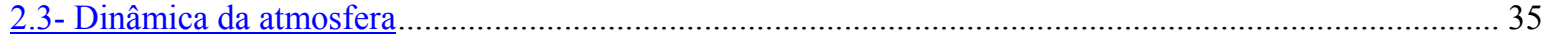

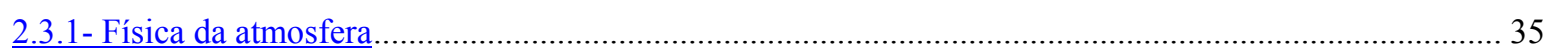

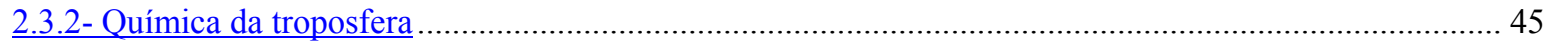

2.3.3- Bacia Aérea (Meio Suporte e Conceito Bolha) ………….............................................................. 51

3- JUSTIFICATIVAS PARA AS ALTERAÇÕES NO LICENCIAMENTO..................................................... 57

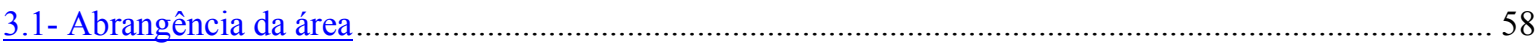

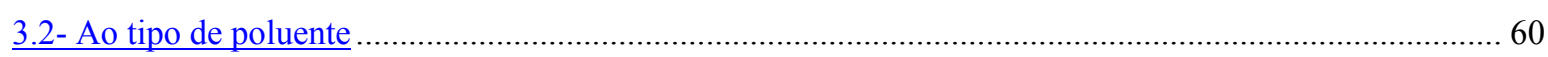

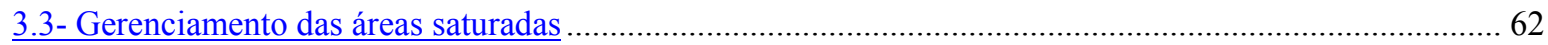

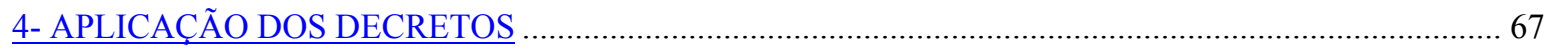

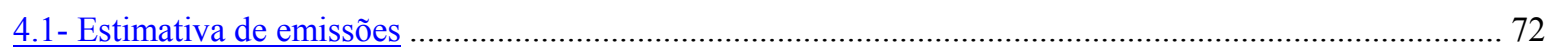

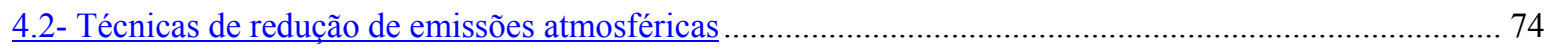

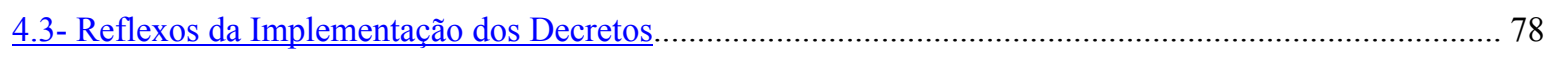

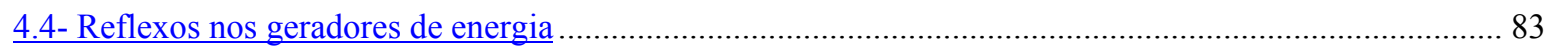

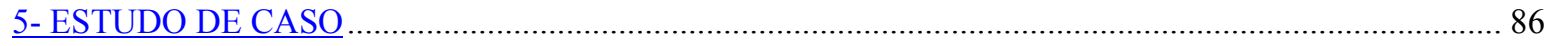

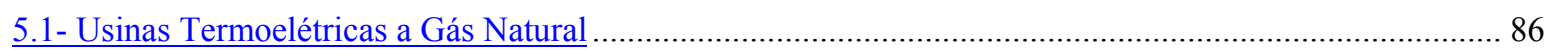

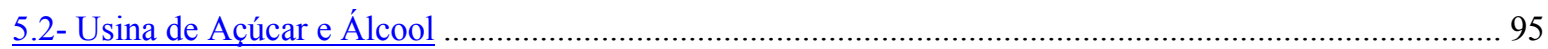

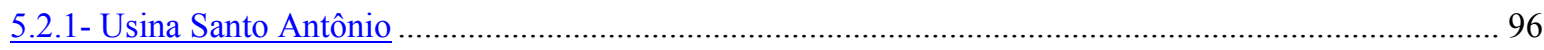

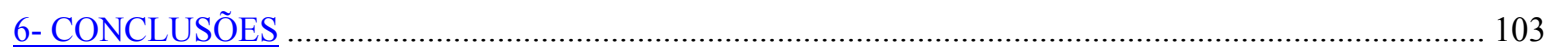

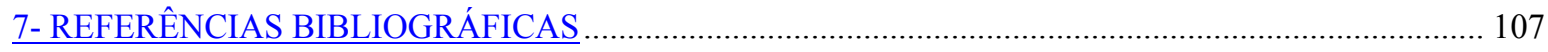

ANEXO 1 - DECRETO N. 48.523, DE 02 DE MARÇO DE 2004 ……...................................................... 115

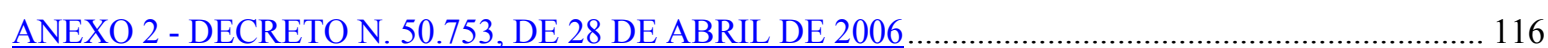

ANEXO 3 - DECRETO N. 52.469, DE 12 DE DEZEMBRO DE 2007 …….............................................. 121 


\section{1- INTRODUÇÃO}

A gestão de bacias aéreas para o desenvolvimento procurou ser um estudo que, inicialmente temos a impressão de se tratar de uma pesquisa apenas de valor, por tratar de um tema conceitual mas também apresenta elementos de cunho empírico, na medida em que busca, através de seus estudos de caso e do levantamento de informações ambientais, apontar as virtudes e defeitos que a alteração da legislação ambiental no Estado de São Paulo recentemente traz, sobretudo pelo seu caráter arrojado e inovador no trato das questões ambientais e em particular aos empreendimentos geradores de energia no Estado de São Paulo.

Os pedidos de licenciamento recebidos pelo sistema de meio ambiente, principalmente dos empreendimentos com grande aporte de carga poluente ao meio, chamados no jargão ambiental de "grandes potenciais", tem feito com que o poder público e a sociedade local manifestem preocupação quanto à degradação da qualidade ambiental da região em que se localizam.

Questões ambientais viabilizam ou inviabilizam investimentos em uma dada região, influenciando economicamente no desenvolvimento desta. Decisões de investimento já apresentam considerações de ordem ambiental, quer seja no licenciamento, quer na atividade do empreendimento são consideradas, inclusive com instituições de fomento a crédito como o Banco Mundial incorporando exigências neste sentido e no Brasil linhas de crédito verdes do Banco Real e Itaú são exemplos.

O Decreto Estadual n48.523 de 02/03/2004 e o Decreto Estadual nº50.753 de 28/04/2006 e mais recentemente o Decreto Estadual n ${ }^{\circ} 52.469$ de 12/12/2007 introduziram alterações significativas no Regulamento da Lei nº97/76 e por consegüinte no Decreto Estadual nº.468/76, definindo os critérios para estabelecimento dos graus de saturação da qualidade do ar de uma sub-região quanto a um poluente específico, possibilitando a CETESB, nas sub-regiões em vias de saturação e nas saturadas, fazer exigências especiais para as atividades em operação, com base nas metas, planos e programas de prevenção e controle de poluição, quer na renovação da licença de operação, quer durante sua vigência, incentivando a competitividade e a inovação tecnológica. 
Assim como o que a Resolução CONAMA no357 de 17 de março de 2005 que introduz o conceito de zona de mistura com relação à gestão da qualidade das águas, a gestão de bacias aéreas busca no meio aéreo o desenvolvimento sustentável da região e o incentivo a investimentos sem prejuízos ao meio ambiente. O artifício de comercialização de "créditos" para poluentes regulamentados e reflexos nos empreendimentos geradores de energia elétrica no território paulista são apontados e analisados.

Este trabalho mostra os conceitos que circundam o tema e implícitos à compreensão do texto legal. Também apresenta a forma como está sendo a implementação e aplicação destas normas no processo de licenciamento no Estado de São Paulo, pelo órgão de meio ambiente e reflexos nos setores industriais e na sociedade.

Salienta-se ainda que se trata de um tema inovador, arrojado e ainda passível de alterações uma vez que tem de se aperfeiçoar e melhorar constantemente o texto de lei para, cada vez mais atingir-se os objetivos (qualidade ambiental) no enfrentamento das questões ambientais e de desenvolvimento econômico.

\section{1- Objetivos da pesquisa}

\subsection{1- Gerais}

O objetivo principal deste tema de mestrado é apurar as implicações que as alterações promovidas na lei ambiental paulista causam em suas várias instâncias e dimensões. Quais os reflexos que as alterações realizadas na legislação ambiental do Estado de São Paulo são esperados quando do gerenciamento das bacias aéreas pelo órgão administrador público executivo (órgão licenciador), pelo setor industrial (especificamente geradores de energia) e pela sociedade.

Embora pareça se tratar de uma pesquisa apenas de valor, por ser um tema de conceito, também trará elementos de cunho empírico, na medida em que busca aplicar e validar a norma através de seus estudos de caso e do levantamento de informações ambientais em processos de licenciamento já apresentados ao Sistema de Meio Ambiente. 


\subsection{2- Específicos}

Analisar os aspectos principais que nortearam essas decisões por parte do órgão ambiental quando da aprovação de um decreto que institui o conceito de gestão de bacias aéreas, neste caso a CETESB- Companhia de Tecnologia de Saneamento Ambiental do Estado de São Paulo, cuja atribuição é a do controle da poluição, a preservação e melhoria da qualidade do meio ambiente através do gerenciamento das bacias aéreas para os poluentes regulamentados.

Os licenciamentos de novos empreendimentos no Estado de São Paulo e o controle preventivo e corretivo dos empreendimentos já existentes que foram enquadrados nesta classificação, tendo a obrigação mandatória de melhoria contínua através da sua inclusão no PREA - Programa de Redução de Emissões Atmosféricas, conforme estipulado pelos Decretos já mencionados.

Aspectos técnicos como análise destas compensações de emissões de poluentes atmosféricos, criação dos "créditos" de emissões, competitividade com proteção ambiental e reduções de emissões de poluentes via melhorias tecnológicas em processos existentes necessitam de reflexão, uma vez que inaugura-se uma nova fase - a da gestão ambiental - onde a indústria e a sociedade são partícipes na geração de soluções e obtenção de resultados.

Estando a norma em vigor, as implicações desta no órgão ambiental quanto nos geradores de energia do Estado são analisados procurando, através de 2 (dois) estudos de caso mensurar a aplicabilidade da norma. Os empreendimentos escolhidos foram a Usina Termoelétrica de Capuava, município de Santo André e a Usina de Açúcar e Álcool de Santo Antônio, no município de Sertãozinho. As escolhas se deram em virtude principalmente das características peculiares das usinas em questão, geradores de energia elétrica através do processo de combustão (bagaço no caso das usinas de açúcar e álcool - UAA e gás natural no caso das usinas termoelétricas - UTE) e pela necessidade do Estado de São Paulo de garantir os padrões de qualidade e de severidade do ar no que se refere ao poluente secundário ozônio troposférico (bacia saturada). 


\section{2- Metodologia}

Neste estudo foram utilizadas informações de domínio público do sistema de licenciamento para a análise técnica comparada dos artigos dos decretos de 2004, 2006 e 2007 com o decreto anterior, propiciando identificar os motivos que foram considerados para a alteração do licenciamento ambiental no Estado de São Paulo.

As questões de base conceitual (fontes de poluição, formação de poluentes na atmosfera, efeitos à saúde, licenciamento ambiental e capacidade suporte) tomaram como base dados disponíveis dos processos de licenciamento ambiental - EIA (Estudo de Impacto Ambiental) e RIMA (Relatório de Impacto Ambiental), palestras e apresentações disponíveis na Internet e informações obtidas junto a profissionais das respectivas áreas de saúde pública e de meio ambiente principalmente.

Também utilizaram-se informações disponíveis na rede mundial de computadores (internet), disponibilizadas por universidades e órgãos de meio ambiente, com especial referência ao site da EPA- Environmental Protection Agency dos EUA e a Califórnia Air Proterction Agency, mais especificamente o ARB - Air Resourses Board, órgão governamental do Estado da Califórnia onde são utilizados os índices mais restritivos no que se refere a padrões de qualidade e de emissão de poluição do ar, em virtude de suas condições geográficas e meteorológicas locais. Experiência similiar também fora encontrada no Chile, embora os modelo adotado no Brasil seja mais amplo e reflete melhor a realidade da bacia aérea e da sistemática do licenciamento aplicado no país.

Para os estudos de casos, tanto da UAA de Santo Antônio (em Sertãozinho) quanto da UTE de Capuava (em Santo André), os processos ambientais e reunião de dados secundários de relatórios divulgados e informações dos licenciamentos ambientais de empresas do mesmo setor industrial foram à base para se obter uma estimativa das emissões adicionadas a suas respectivas bacias aéreas. Salienta-se que as informações apresentadas estão em consonância com a Resolução SMA n66/96 e garantia de informação pelos órgão públicos pela Constituição Federal, Artigo $5^{\circ}$, inciso XXXIII, ressalvadas aquelas cujo sigilo seja imprescindível à segurança da sociedade e do Estado, o que não foi o caso. 
Assim, esta dissertação inicia-se com a apresentação das bases conceituais, apresentando os conceitos envolvidos para a análise das questões a que se referem os decretos que alteram a sistemática do licenciamento ambiental no Estado de São Paulo. Seguem-se: O histórico da poluição do ar (seção 2.1) mostrando a evolução da preocupação com o tema e os efeitos da poluição do ar (2.2) nos seres vivos: animais, vegetais e construções.

Ainda pertencentes ao capítulo segundo estão as seções referentes à dinâmica da atmosfera (2.3), sugerida àquele leitor que não se sinta suficientemente engajado com os termos ambientais da norma. A física da atmosfera (2.3.1) onde a atmosfera é definida em seus limites e efeitos físicos principais e na seção 2.3.2 segue-se a química da atmosfera, onde os poluentes atmosféricos regulamentados são apresentados, além da pontuação das fontes de poluição e dos fenômenos químicos e interações no meio aéreo, além da integração e interação da físico-química na atmosfera na seção denominada bacia aérea (2.3.3), onde o conceito ecológico é explorado e valida o texto legal.

No capítulo terceiro é apresentada a justificativa do tema onde, através da comparação das alterações promovidas no Decreto Estadual n8.468/76 pelos Decretos Estaduais n ${ }^{\circ} 48.523 / 04$, $\mathrm{n}^{\circ} 50.753 / 06$ e n52.469/07, procuram-se mostrar os motivos que levaram a mudança na forma de licenciamento de empreendimentos no território paulista. Para fins de comparação entre as normas chamou-se aqui de redação anterior o texto do Decreto Estadual n8.468/76 e suas alterações anteriores à publicação dos Decretos Estaduais n48.523/04 e 50.753/06 (nova redação) e da novíssima redação com texto aprovado em 2007 (Decreto Estadual n 52.469/07).

No quarto capítulo é colocada a aplicação do decreto, iniciando-se pela seção 4.1 que traz as estimativas de emissões utilizadas no Estado de São Paulo e as técnicas de redução dessas emissões (4.2), além reflexos causados com implementação dos decretos (4.3), com a reação dos atores.

No capítulo cinco são apresentados estudos de casos, tendo sido escolhidas uma usina termelétrica e uma usina geradora de açúcar e álcool. As considerações de uma região saturada (Santo André) e em vias de saturação (Ribeirão Preto) e de um poluente específico $\left(\mathrm{NO}_{\mathrm{x}}\right)$ são 
necessários e levam em conta as características principais do Estado de São Paulo, quer em sua característica industrial e de poluição do ar.

As considerações e contribuições são apontadas no capítulo sexto (conclusão), seguindo-se pelas referências bibliográfias (capítulo sétimo) e anexos. 


\section{2- CONCEITOS ENVOLVIDOS}

Neste capítulo são expostos conceitos iniciais sobre as questões relacionadas à atmosfera, iniciando-se pelo entendimento histórico das questões de poluição do ar que hoje são sentidos e presente, bastando analisarmos os casos de atendimento nos hospitais no inverno, quando as condições de dispersão de poluentes são desfavoráveis (Seções 2.1 e 2.2).

A constituição da atmosfera, no que se referente à composição dos gases constituintes, fontes de emissão de poluentes e dinâmica de suas interações é colocada na próxima seção deste capítulo (Seção 2.3), embora para aqueles leitores que já se sintam com um bom embasamento conceitual na área ambiental e em questões relacionadas à atmosfera esta seção possa não ser imprescindível, passando-se assim para o próximo capítulo.

\section{1- Histórico da poluição do ar}

O ar é vital para a manutenção da vida. Guardadas as devidas diferenças entre metabolismos pode-se dizer que um ser humano é capaz de permanecer 70 dias sem comida, uns 7 dias sem água e não mais que 7 minutos sem ar.

A qualidade deste também é importante e neste sentido alguns relatos e fatos históricos sobre episódios críticos de poluição foram sintetizados na tabela 2.1, considerando eventos de origem antropogênica.

Tabela 2.1- Histórico dos principais episódios críticos de poluição do ar

\begin{tabular}{|c|c|c|}
\hline Ano & Região & Evento \\
\hline 2000 A.C. & Itália (Roma) & $\begin{array}{l}\text { Surgem os primeiros relatos de reclamações referentes à } \\
\text { poluição do ar. }\end{array}$ \\
\hline 1273 & Inglaterra (Londres) & $\begin{array}{l}\text { Rei Eduardo da Inglaterra assinou as primeiras leis de } \\
\text { qualidade do ar, proibindo o uso de carvão com alto teor de } \\
\text { enxofre. Proibiu também a queima de carvão em Londres } \\
\text { durante as sessões do Parlamento, por causa da fumaça e } \\
\text { do odor produzidos (PERKINS, 1974). }\end{array}$ \\
\hline Séc. XVIII & Europa & $\begin{array}{l}\text { James Watt introduz a máquina a vapor, dando início à } \\
\text { Revolução Industrial com uso intensivo de combusíveis } \\
\text { (carvão mineral, petróleo e gás). Em } 1845 \text { o Parlamento } \\
\text { inglês aprovou lei exigindo o controle da fumaça em } \\
\text { locomotivas (ASSUNÇÃO \& PESQUERO, 2006). }\end{array}$ \\
\hline 1911 & Inglaterra (Londres) & $\begin{array}{l}\text { Primeiro desastre decorrente da poluição atmosférica com } \\
1150 \text { mortes em decorrência da fumaça. }\end{array}$ \\
\hline
\end{tabular}


CONTINUAÇÃO.

\begin{tabular}{|c|c|c|}
\hline Ano & Região & Evento \\
\hline$\overline{1930}$ & Bélgica (Vale do rio Meuse) & $\begin{array}{l}\text { Região de numerosas indústrias, formação de gotículas de } \\
\text { ácido sulfúrico, congestão intensa das vias respiratórias, } \\
\text { morte do gado e } 60 \text { mortes de seres humanos. }\end{array}$ \\
\hline Déc. 40 & EUA (Los Angeles) & $\begin{array}{l}\text { Smog* fotoquímico causado pôr veículos, presença de } \\
\text { óxidos de nitrogênio e hidrocarbonetos na atmosfera } \\
\text { associado a partícula. }\end{array}$ \\
\hline 1948 & EUA (Donora) & $\begin{array}{l}\text { Região metalúrgica, alta concentração de material } \\
\text { particulado e óxidos de enxofre, } 14.000 \text { habitantes doentes } \\
\text { e } 17 \text { mortes. }\end{array}$ \\
\hline 1952 & Inglaterra (Londres) & $\begin{array}{l}\text { Smog fotoquímico doenças respiratórias com número de } \\
\text { mortes }=3500 \text { a } 4000 \text {. }\end{array}$ \\
\hline 1952 & Brasil (Bauru) & $\begin{array}{l}\text { Fábrica de óleo de mamona, emissão do pó da semente da } \\
\text { mamona, doenças respiratórias agudas e afecções } \\
\text { alérgicas com } 150 \text { casos de doença e } 9 \text { mortes. }\end{array}$ \\
\hline 1955 & México (Poza Rica) & $\begin{array}{l}\text { Indústria de recuperação de enxofre do gás natural, } \\
\text { emissão de gás sulfídrico, doenças respiratórias e nervosas } \\
\text { deixando } 320 \text { pessoas hospitalizadas e } 22 \text { mortes. }\end{array}$ \\
\hline 1955 & EUA (Nova Orleans) & $\begin{array}{l}\text { Poeira de indústria de farinha, aumento da freqüência de } \\
\text { asma. }\end{array}$ \\
\hline 1956 & EUA (Mineapolis) & Indústrias de cereais, epidemia de asma. \\
\hline 1963 & EUA (Nova York) & $\begin{array}{l}300 \text { pessoas morreram e milhares com problemas } \\
\text { respiratórios. }\end{array}$ \\
\hline
\end{tabular}

1984

Déc. 70 e 80:

(Índia) Bhopah Liberação acidental de isocianato de metila, resultando na morte de cerca de 2000pessoas.

Dec. 60

Grandes Centros Cidade do México, Los Angeles, Detroit, São Paulo, Londres, Tóquio e Osaka com episódios crtíticos de poluição do ar.

Brasil (ABC) Era da indústria automobilística - Pólo de indústrias automobilísticas (Volkswagen, Ford e General Motors) e indústrias de apoio (siderúrgicas, fundições, mecânicas, químicas e etc.). Smog fotoquímico na época de inverno.

Dec. 80

Brasil (Cubatão) Parque industrial de grande porte. Registro de altos níveis de poluição do ar, principalmente MP com episódios críticos e impactos à população e ao ecossistema (vegetação da Serra do Mar), o que exigiu esforços do governo, empresas e sociedade na reversão dos problemas.

* Smog = smoke+fog (neblina + altas concentrações de poeira e óxidos de enxofre)

Fonte: SIQUEIRA (2002); PERKINS (1974), ASSUNÇÃO \& PESQUERO (2006) e elaboração própria

Mage et al. (1995) colocada o esforço mundial no desenvolvimento de rede de monitoramento da qualidade do ar, através do GEMS - Global Environment Monitoring System em 1976 e a evolução da legislação e recomendações da OMS - Organização Mundial da Saúde no que se refere ao métodos de amostragem e de exposição.

Russo (2007) assinala que a Rede Panamericana de Amostragem de Contaminantes Atmosféricos (REDPANARE) teve suas atividades iniciadas em junho de 1967, tendo sido incorporada ao Programa Global de Monitoramento da Qualidade do Ar, estabelecido em 1980 
pela OMS e pelo Programa das Nações Unidas para o Meio Ambiente (PNUMA), como parte do Sistema Mundial de Monitoramento do Meio Ambiente.

A tabela 2.2 mostra a evolução da poluição em nível global dos principais poluentes amostrados pelo GEMS ( $\left.\mathrm{SO}_{\mathrm{x}}, \mathrm{MP}, \mathrm{NO}_{\mathrm{x}}, \mathrm{CO}, \mathrm{Pb}\right)$ no período de 1973 a 1985 e considera países da Ásia, Europa, América do Norte e Central e Oceania.

Tabela 2.2- Evolução da poluição em nível global dos principais poluentes amostrados pelo GEMS entre período de 1973 a 1985

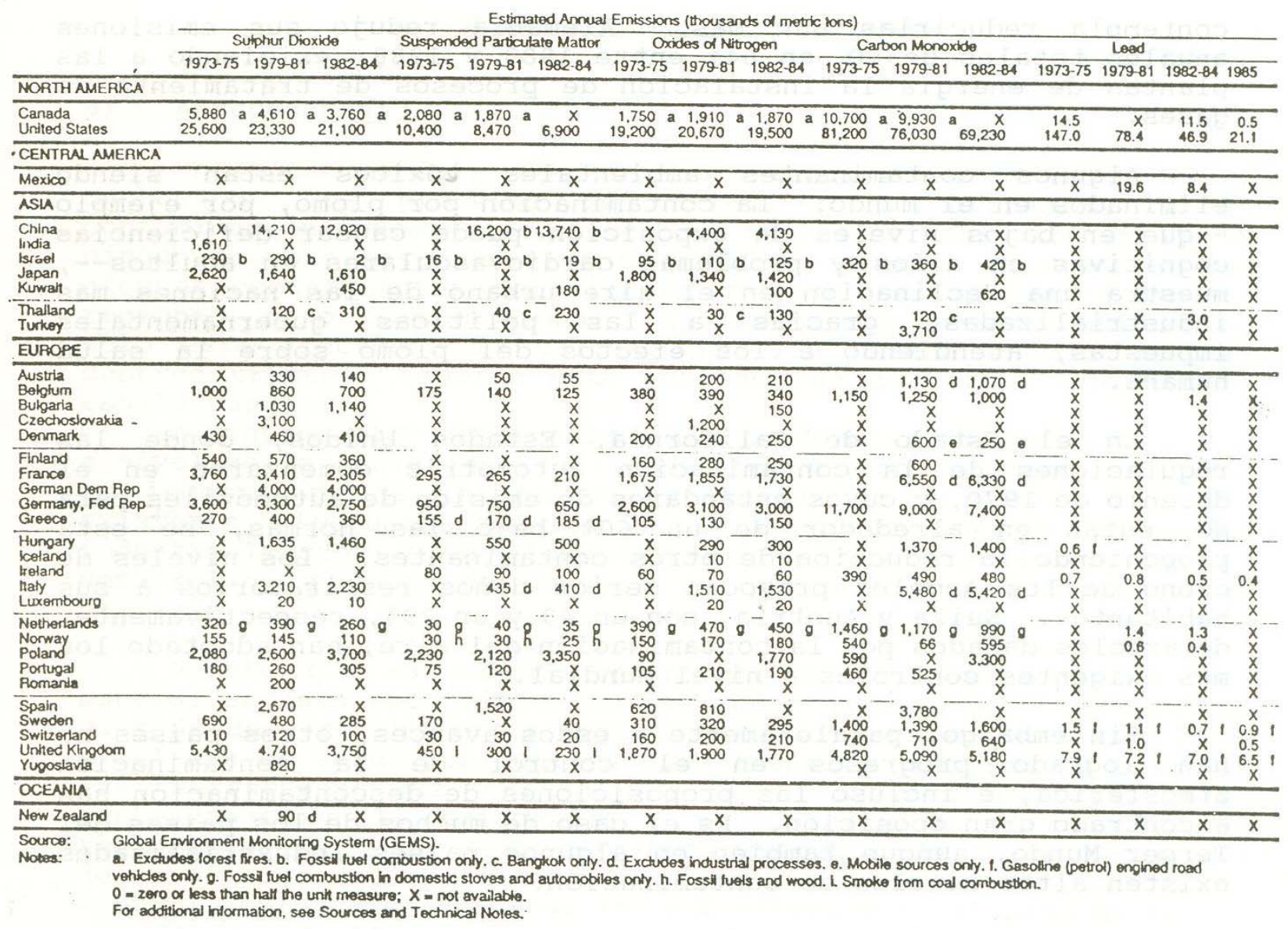

Fonte: CEPAL \& PNUMA (1991)

Ainda segundo Mage et al. (1995) a questão da poluição do ar segue pelos anos 90 com a inclusão de normas e métodos para poluição do ar em ambientes fechados (cigarro, cocção e fontes de poluição fechada). Também os impactos à vegetação passam a serem considerados nesta época. Por fim, a análise de emissões de poluição regional e global, além dos gases de 
efeito estufa são temas de análises nos "aglomerados" urbanos ou super-cidades e pauta das discussões atuais.

\section{2- Efeitos da poluição do ar}

Os efeitos da poluição do ar são percebidos nas propriedades da atmosfera, nos ecossistemas, nos materiais, na saúde dos indivíduos e outros.

Nos últimos 100 anos, em que a população do mundo pelo menos triplicou, os danos ambientais locais e globais se intensificaram. O aumento no uso de combustíveis fósseis resultou na emergência da ação do homem como uma força geoquímica e ecológica global; em outras palavras, o impacto acelerado da vida na Terra está afetando o mundo como um todo (GOLDEMBERG et al., 2003).

Esta degradação ameaça a saúde humana e a qualidade de vida, além de afetar o equilíbrio ecológico e a diversidade biológica. Além dos impactos globais da poluição, a degradação local da atmosfera é tão ou igualmente preocupante. A exposição a uma atmosfera (baixa troposfera) poluída ou contaminada causa uma série de efeitos, sendo que, na maioria dos casos é adverso.

A interação entre as fontes de poluição e a atmosfera vai definir o nível de qualidade do ar, que determina por sua vez o surgimento de efeitos adversos da poluição do ar sobre os receptores, que podem ser o homem, os animais, as plantas e os materiais.

\subsection{1- Efeitos sobre as propriedades físicas da atmosfera}

Na seção 2.3 (Dinâmica da Atmosfera) serão pontuadas algumas características físico-químicas da atmosfera. A alteração das condições médias do ar pode causar os seguintes efeitos:

- Redução da Visibilidade: Levantamento de poeiras pela ação dos ventos; Grande número de partículas e gases devido aos processos de combustão (queimadas, industrias).

- Formação de neblinas: Lançamento de gotículas d'água com produtos químicos dissolvidos.

- Radiação urbana: Diminui em áreas poluídas, devido a perda da iluminação natural.

- Efeito estufa: O aumento do $\mathrm{CO}_{2}$ na atmosfera aumenta a temperatura da superfície, causando o efeito estufa e alterações no clima. 
- Chuva Ácida: Compreende várias formas: chuva, neve, granizo, neblina ou partículas secas e têm como principais fontes os óxidos de enxofre e nitrogênio lançados para atmosfera, os quais combinados com a umidade do ar produzem a chuva ácida. A tolerância dos ecossistemas não é a mesma para a chuva ácida e alguns tipos de solo com formação alcalina ajudam a neutralizar a acidez, bem como lagos que possuem águas que repousam sobre leitos com limo, pedras arenosas ou formações alcalinas, sendo que os que não possuem a tolerância, podem ser severamente agredidos.

\subsection{2- Efeitos sobre a saúde}

A poluição do ar é caracterizada pela Organização Mundial da Saúde como um fator de risco para várias doenças como infecções respiratórias agudas, doenças pulmonares obstrutivas crônicas, asma e infecções respiratórias das vias aéreas superiores (garganta, nasofaringe, sinus, laringe, traquéia e brônquios). A exposição humana pode se dar por inalação, ingestão ou contato com a pele, mas a inalação pode ser considerada a via mais importante e mais vulnerável (PHILIPPI Jr. et al., 2004).

Siqueira (2002) aponta que os efeitos fisiológicos correlacionados com a poluição do ar ocorrem em episódios críticos. No entanto, muitos problemas de saúde causados pela poluição do ar não são identificáveis, por não serem associados a algum episódio crítico, uma vez que pode ocorrer exposição diária a diversos poluentes, como numa área urbana e a saúde se degrada gradativamente.

Estudos toxicológicos e epidemiológicos evidenciam o aumento nas taxas de morbi/mortalidade em áreas sujeitas à poluição atmosférica. Nessas áreas, a população fica sujeita à maior incidência de doenças do aparelho respiratório (asmas, bronquites, enfizemas, pneumoconioses e edemas pulmonares), dores de cabeça, irritação nos olhos, doenças dermatológicas e gastrointestinais, redução da capacidade pulmonar e, em situações mais críticas, alterações motoras, enzimáticas e genéticas, danos ao sistema nervoso central, efeitos teratogênicos e cânceres.

É importante mencionar que os efeitos da poluição do ar podem variar conforme o tipo e a concentração dos poluentes, os volumes aspirados, o tempo de exposição e as condições 
fisiológicas de cada organismo. Entretanto é sabido que nas grandes cidades as crianças e idosos sofrem maiores conseqüências da exposição à poluição, influindo na saúde e qualidade de vida dessa faixa populacional.

Saldiva et al. (2001a) afirma que crianças e adolescentes têm se mostrado bastante susceptíveis aos efeitos da poluição do ar. Nestes grupos etários, acréscimos no número de internações por doenças respiratórias têm sido associados a acréscimos nos níveis de poluentes atmosféricos urbanos. O mesmo se observa entre os idosos. Entretanto, neste grupo, além de promover aumentos na morbidade e na mortalidade por doenças respiratórias, os poluentes do ar apresentam efeitos deletérios sobre a morbidade e a mortalidade por causas cardiovasculares.

(GOUVEIA \& FELTCHER. 2006) apresentam em inúmeros estudos associações significativas entre níveis diários de material particulado inalável com diâmetro $<10 \mu \mathrm{m}$ para material particulado $\left(\mathrm{PM}_{10}\right)$, monóxido de carbono $(\mathrm{CO})$, ozônio $\left(\mathrm{O}_{3}\right)$ e outros poluentes e uma série de efeitos na saúde que vão desde mortalidade total na população passando por adoecimentos para causas específicas, até malformações congênitas ou menor ganho de peso durante a gestação.

A tabela 2.3 que se segue apresenta dados do Ministério da Saúde, obtidos do programa de Vigilância dos Efeitos na Saúde Relacionados à Poluição do Ar (VIGIAR) que buscam analisar a associação entre exposição à poluição do ar e internações hospitalares para causas específicas de doenças respiratórias e cardiovasculares em idosos e crianças no município de São Paulo, maior metrópole brasileira, que conta com competentes serviços de monitoramento da qualidade do ar, dispõe de estatísticas de morbidade de qualidade adequada e, sobretudo, possui grande contingente populacional exposto a níveis de poluição do ar potencialmente prejudiciais à saúde e teve como objetivo principal é fornecer subsídios para a elaboração de medidas que visem reduzir os riscos à saúde associados à poluição do ar. 
Tabela 2.3- Estatística descritiva dos níveis de poluição, variáveis meteorológicas e das internações de idosos e crianças, São Paulo, Brasil, 1996-2000

\begin{tabular}{|c|c|c|c|c|c|c|c|c|}
\hline Parâmetros & n (dias) & Média & DP & $\begin{array}{l}\text { Valor } \\
\text { mínimo }\end{array}$ & $25 \%$ & $50 \%$ & $75 \%$ & $\begin{array}{l}\text { Valor } \\
\text { máximo }\end{array}$ \\
\hline $\mathrm{PM}_{10}\left(\mu \mathrm{g} / \mathrm{m}^{3}\right)$ & 1.461 & 54,49 & 25,24 & 13,93 & 37,04 & 48,57 & 64,56 & 186,25 \\
\hline $\mathrm{SO}_{2}\left(\mu \mathrm{g} / \mathrm{m}^{3}\right)$ & 1.459 & 17,71 & 9,86 & 2,58 & 10,54 & 15,38 & 22,83 & 75,24 \\
\hline $\mathrm{CO}$ (ppm) & 1.459 & 3,24 & 1,64 & 0,54 & 2,17 & 2,86 & 3,87 & 12,58 \\
\hline $\mathrm{NO}_{2}\left(\mu \mathrm{g} / \mathrm{m}^{3}\right)$ & 1.452 & 103,46 & 51,18 & 19,00 & 68,05 & 93,73 & 127,97 & 421,62 \\
\hline $\mathrm{O}_{3}\left(\mu \mathrm{g} / \mathrm{m}^{3}\right)$ & 1.460 & 71,79 & 41,99 & 7,82 & 42,41 & 61,85 & 91,69 & 389,45 \\
\hline Temperatura $\left({ }^{\circ} \mathrm{C}\right)$ & 1.461 & 19,21 & 3,45 & 7,13 & 16,70 & 19,15 & 22,01 & 28,34 \\
\hline Umidade relativa (\%) & 1.461 & 81,29 & 8,06 & 48,45 & 77,08 & 81,98 & 86,79 & 96,63 \\
\hline \multicolumn{9}{|l|}{ Internações em idosos } \\
\hline Respiratónias & 1.461 & 14,76 & 5,41 & 1 & 11 & 14 & 18 & 36 \\
\hline DPOC & 1.461 & 3,59 & 2,58 & 0 & 2 & 3 & 5 & 19 \\
\hline Pneumonias & 1.461 & 5,94 & 3,07 & 0 & 4 & 6 & 8 & 20 \\
\hline Circulatórias & 1.461 & 43,38 & 15,71 & 10 & 32 & 43 & 52 & 165 \\
\hline Doença isquêmica do coração & 1.461 & 8,60 & 3,83 & 0 & 6 & 8 & 11 & 21 \\
\hline \multicolumn{9}{|l|}{ Internações em crianças } \\
\hline Respiratónias & 1.461 & 37,77 & 14,73 & 7 & 27 & 36 & 46 & 95 \\
\hline Asma & 1.461 & 6,19 & 3,47 & 0 & 4 & 6 & 8 & 27 \\
\hline Pneumonias & 1.461 & 22,48 & 10,09 & 3 & 15 & 21 & 28 & 65 \\
\hline
\end{tabular}

$D P=$ desvio padrăo; $D P O C=$ doença pulmonar obstrutiva crônica.

Fonte: GOUVEIA \& FELTCHER (2006)

Observam-se que as médias do $\mathrm{PM}_{10}$ e do $\mathrm{NO}_{2}$ ultrapassaram os padrões anuais de qualidade do ar $\left(50 \mu \mathrm{g} / \mathrm{m}^{3}\right.$ e $100 \mu \mathrm{g} / \mathrm{m}^{3}$, respectivamente) no período estudado, o que não ocorreu com o $\mathrm{SO}_{2}$. Na observação dos dados ano a ano, Gouveia \& Feltcher (2000) verificaram que o $\mathrm{O}_{3}$ apresentou níveis crescentes, ao contrário dos demais poluentes (dado não apresentado). Em relação às internações registradas, pode-se observar que as doenças circulatórias em idosos vêm em primeiro lugar, seguidas das doenças respiratórias em crianças. Dentre estas, pneumonia foi o diagnóstico mais freqüente. As internações respiratórias em crianças correspondem a cerca de $30 \%$ do total de internações observadas no período nessa faixa etária, enquanto as hospitalizações por doença isquêmica do coração em idosos representam aproximadamente 14\% das internações observadas nesse grupo.

(GOUVEIA \& FELTCHER. 2000) apresenta que quando da elaboração dos valores, os coeficientes obtidos dos modelos de regressão foram transformados por exponenciação em riscos relativos (RR) de hospitalização para um incremento de $10 \mu \mathrm{g} / \mathrm{m}^{3}$ ou $1 \mathrm{ppm}$ nos níveis médios diários dos poluentes ambientais, apresentados na tabela 2.4. Os resultados são também 
apresentados como aumento percentual nas internações, que são obtidos dos RR pela fórmula (programa estatístico S-Plus -Mathsoft Inc., Seattle, Estados Unidos):

$$
\text { Aumento \% }=(\mathbf{R R}-1) * 100
$$

Tabela 2.4- Riscos relativos (RR) e intervalo de confiança de 95\% (IC95\%) de internações por doenças em crianças para um incremento de $10 \mathrm{mg} / \mathrm{m} 3$ nos níveis de PM10, SO2, NO2 e O3 e de 1ppm para o CO. São Paulo, Brasil, 1996-2000

\begin{tabular}{lccc}
\hline Doenças & Niveis & RR & IC95\% \\
\hline Doenças respiratórias & $\mathrm{PM}_{10}$ & 1,024 & $1,017-1,031$ \\
& $\mathrm{SO}_{2}$ & 1,067 & $1,049-1,086$ \\
& $\mathrm{CO}$ & 1,019 & $1,007-1,030$ \\
& $\mathrm{NO}_{2}$ & 1,009 & $1,005-1,013$ \\
& $\mathrm{O}_{3}$ & 1,008 & $1,003-1,012$ \\
Asma & $\mathrm{PM}_{10}$ & 1,046 & $1,033-1,060$ \\
& $\mathrm{SO}_{2}$ & 1,109 & $1,072-1,148$ \\
& $\mathrm{CO}^{*}$ & 1,054 & $1,032-1,077$ \\
& $\mathrm{NO}_{2}$ & 1,023 & $1,015-1,030$ \\
& $\mathrm{O}_{3}$ & 1,016 & $1,007-1,025$ \\
& $\mathrm{PM}_{10}$ & 1,021 & $1,014-1,029$ \\
& $\mathrm{SO}_{2}$ & 1,053 & $1,033-1,074$ \\
& $\mathrm{CO}^{*}$ & 1,018 & $1,006-1,030$ \\
& $\mathrm{NO}_{2}$ & 1,008 & $1,004-1,012$ \\
& $\mathrm{O}_{3}$ & 1,005 & $1,000-1,010$
\end{tabular}

Fonte: GOUVEIA \& FELTCHER (2000)

A tabela 2.4 apresenta o risco relativo ajustado de internações por doenças respiratórias em crianças para incrementos nos níveis diários de poluição, apresentando associação positiva para todos os poluentes com as internações por doenças respiratórias totais. Segundo o mesmo estudo, para as internações por doença respiratória em idosos, os riscos relativos e seus respectivos intervalos de confiança apresentaram associações estatisticamente significantes com as internações por doenças respiratórias totais e os subgrupos pneumonia e doença pulmonar obstrutiva crônica (DPOC), com exceção do $\mathrm{O}_{3}$ que não apresentou associação com as internações por pneumonia.

(ASSUNÇÃO \& PESQUERO. 2006) relatam que os níveis considerados "seguros" são estabelecidos a partir de dados científicos de dose-resposta obtidos através de estudos 
toxicológicos e/ou epidemiológicos ou mesmo de estudos de efeitos em vegetais e materiais inertes e também de informações de episódios ocorridos em diversas regiões.

\subsubsection{1- Níveis de referência}

A tabela 2.5 que se segue apresenta os níveis máximos de poluentes publicados pela OMS nos seus guidelines de qualidade do ar, elaborados para orientar o estabelecimento de níveis de referência.

Tabela 2.4- Níveis máximos de poluentes recomendados pela Organização Mundial da Saúde, para a saúde, exceto câncer e alteração do bem estar

\begin{tabular}{c|c|c}
\hline \multirow{2}{*}{ Indicador } & $\begin{array}{c}\text { Concentração máxima } \\
\text { recomendada } \\
\left(\mu / \mathbf{m}^{3}\right)\end{array}$ & $\begin{array}{c}\text { Tempo de } \\
\text { exposição }\end{array}$ \\
\hline \multirow{2}{*}{ Dióxido de enxofre $\left(\mathrm{SO}_{2}\right)$} & 500 & 10 minutos \\
\cline { 2 - 3 } & 125 & 24 horas \\
\hline \multirow{2}{*}{ Dióxido de nitrogênio $\left(\mathrm{NO}_{2}\right)$} & 50 & 1 hora \\
\cline { 2 - 3 } & 200 & 15 minutos \\
\hline \multirow{2}{*}{ Monóxido de carbono $(\mathrm{CO})$} & 40 & 30 minutos \\
\cline { 2 - 3 } & 100.000 & 8 horas \\
\hline Ozônio $\left(\mathrm{O}_{3}\right)$ & 60.000 & 8 horas \\
\hline Material Particulado* & 10.000 & \\
\hline
\end{tabular}

\footnotetext{
* Tratado como poluente "sem limiar", ou seja, há um risco associado a qualquer exposição, devendo ser observada a curva dose-resposta, deixando para cada país ou estado determinar o nível de risco a ser adotado e em consequência a concentração limite.

Fonte: ASSUNÇÃO \& PESQUERO (2006) apud WHO (2000) modificada
}

A medição sistemática da qualidade do ar é restrita a um número de poluentes, definidos em função de sua importância e dos recursos disponíveis para seu acompanhamento, além de refletirem questões de ordem regional e cultural, razão pela qual existam, em um mesmo país, padrões de qualidade diferentes. Cita-se aqui o caso dos Estados Unidos onde o Estado da Califórnia apresenta padrões de qualidade mais restritivos que os outros estados da federação.

O grupo de poluentes que servem como indicadores de qualidade do ar, adotados universalmente e que foram escolhidos em razão da freqüência de ocorrência e de seus efeitos adversos são: 
- Monóxido de carbono (CO): é uma substância inodora, insípida e incolor - atua no sangue reduzindo sua oxigenação.

- Óxidos de nitrogênio $\left(\mathbf{N O}_{\mathbf{x}}\right)$ : são uma combinação de nitrogênio e oxigênio que se formam em razão da alta temperatura na câmara de combustão - participa na formação de dióxido de nitrogênio e na formação do "smog" fotoquímico.

- Hidrocarbonetos (HC): são combustíveis não queimados ou parcialmente queimados que expelidos pelo motor: alguns tipos de hidrocarbonetos reagem na atmosfera promovendo a formação do "smog" fotoquímico.

\section{- Fuligem (partículas sólidas e líquidas), sob a denominação geral de material particulado} (MP): devido ao seu pequeno tamanho (minúsculas partículas de carbono, embebidas por substâncias oleosas), mantém-se suspensa na atmosfera e pode penetrar nas defesas do organismo, atingir os alvéolos pulmonares e ocasionar mal estar, irritação dos olhos, garganta, pele, dor de cabeça, enjôo, bronquite, asma e até câncer de pulmão.

Com a baixa umidade do ar e a alta concentração de poluentes no inverno, é comum ocorrerem complicações respiratórias devido ao ressecamento das mucosas, provocando sangramento pelo nariz, ressecamento da pele e irritação dos olhos. Outro fator a ser considerado é que as emissões veiculares causam grande incômodo aos pedestres próximos às vias de tráfego. No caso da fuligem (fumaça preta), a coloração intensa e o profundo mau cheiro destas emissões causam, de imediato, uma atitude de repulsa e pode ainda ocasionar diminuição da segurança e aumento de acidentes de trânsito pela redução da visibilidade.

Quanto ao tipo de poluente e sua respectiva concentração, os riscos ou danos à saúde são bastante variáveis. A tabela 2.6 correlaciona os níveis de qualidade do ar com os efeitos à saúde pública. 
Tabela 2.5- Níveis de concentração de poluentes e efeitos à saúde pública

\begin{tabular}{|c|c|c|c|c|c|c|}
\hline 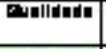 & Tindil & $\begin{array}{l}\text { Infd } \\
\text { Pontin? }\end{array}$ & $\cos _{0}$ & tet & inger & 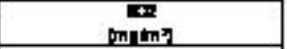 \\
\hline Boa & עי & 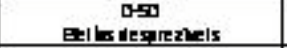 & 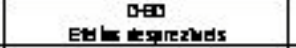 & 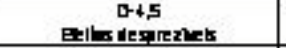 & 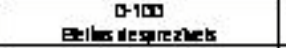 & 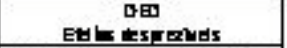 \\
\hline Reoular & 51-10 & 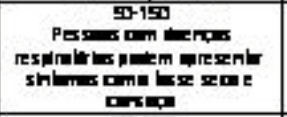 & 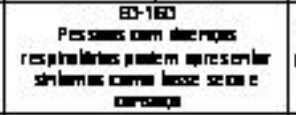 & 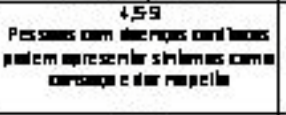 & 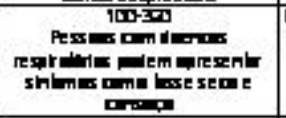 & 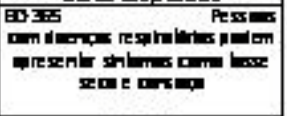 \\
\hline \multirow{2}{*}{ Inadequada } & 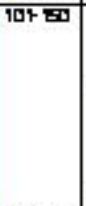 & 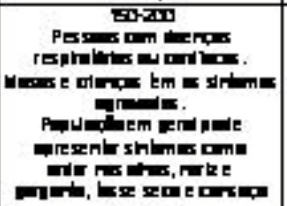 & 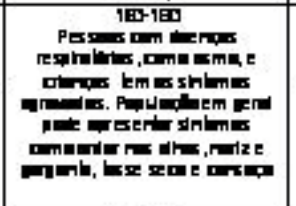 & 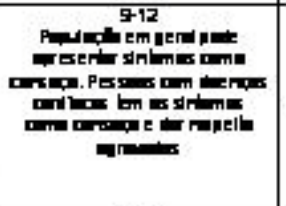 & 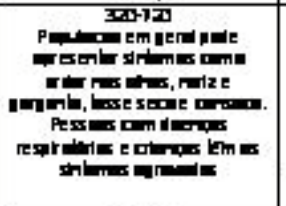 & 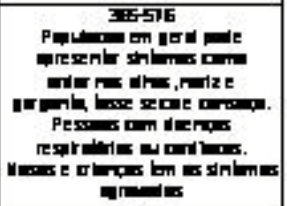 \\
\hline & $15+87$ & 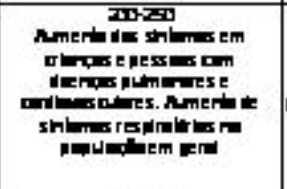 & 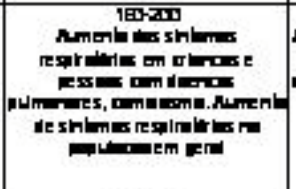 & 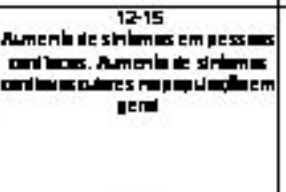 & 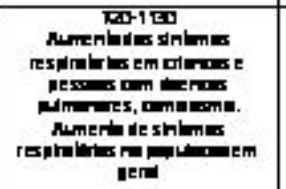 & 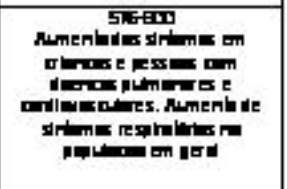 \\
\hline \multirow[b]{2}{*}{ Math } & Antas & 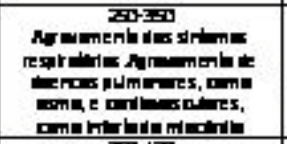 & 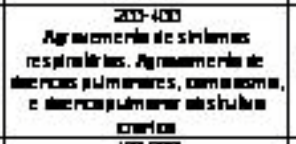 & 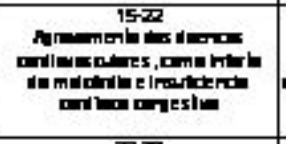 & 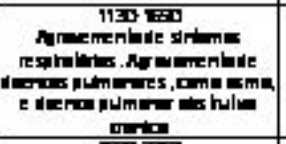 & 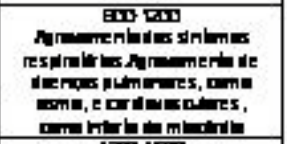 \\
\hline & ZrF & 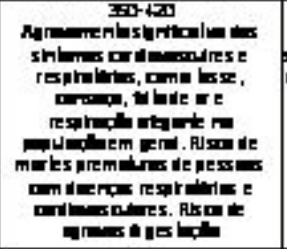 & 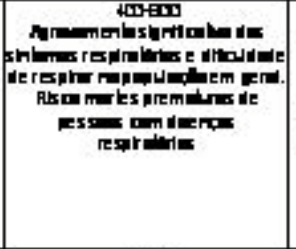 & 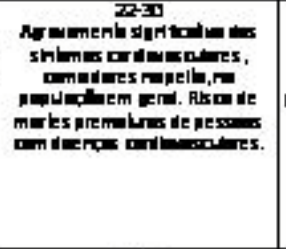 & 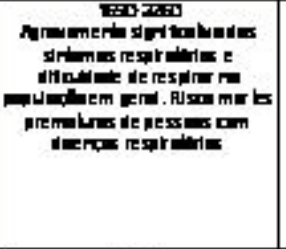 & 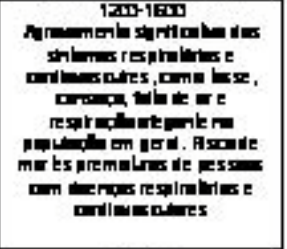 \\
\hline 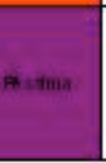 & .ZI & 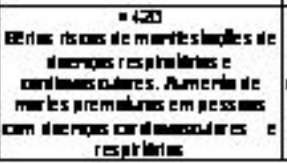 & 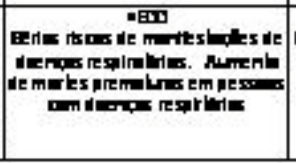 & 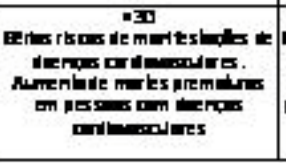 & 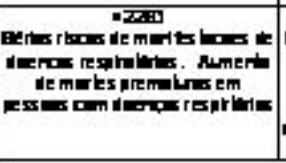 & 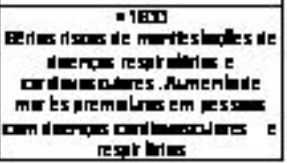 \\
\hline
\end{tabular}

Fonte: CETESB (2007a)

Não serão discutidos aqui os efeitos da poluição do ar em ambientes fechados que, muito embora estejam relacionados ao tema, dependem de uma análise específica devido à pecurialidade do assunto.

\subsubsection{2- Setor de transporte}

Cabe trazer à discussão os efeitos causados pela emissão de poluentes atmosféricos oriundos dos sistemas de transporte.

Saldiva et al. (2001b) realizaram estudo onde os efeitos dos poluentes do ar foram estimados com base nos seus valores médios diários e nas médias móveis de dois a sete dias. Monóxido de carbono $(\mathrm{CO})$ e dióxido de enxofre $\left(\mathrm{SO}_{2}\right)$ estiveram diretamente associados à IVAS (Infecções de vias aéreas superiores) sendo essa associação robusta, resistindo à inclusão das variáveis de controle na presença e ausência do rodízio na RMSP. O rodízio de veículos reduziu os níveis médios dos poluentes (médias diárias de $\mathrm{CO}, \mathrm{PM}_{10}, \mathrm{NO}_{2}$ e $\mathrm{SO}_{2}$ ); entretanto, não foi observada 
diminuição nos atendimentos por IVAS em idosos, mostrando-se assim ser um instrumento útil no controle de pico de poluição atmosférica. Pode-se explicar tal reflexo porque o rodízio desloca o horário das emissões e não as evita.

O mesmo estudo mostra que, alguns países usam o rodízio de automóveis como forma de reduzir poluição atmosférica, como o México e Chile que já possuem este sistema há anos, mas não apresentam o efeito do rodízio na saúde da população. Outros países como França e Itália somente utilizam o rodízio de veículos em situações de emergência.

Segundo CETESBNET (2005) ${ }^{1}$ apresenta o estudo do desperdício de combustível realizado pelo Air Resouces Board em 2003 que, um único veículo a diesel pesado operando em marcha lenta emite gases que contribuem para a poluição local, quantificados em cerca de $25 \mathrm{~g} / \mathrm{h}$ de monóxido de carbono (CO), $4 \mathrm{~g} / \mathrm{h}$ de hidrocarbonetos $(\mathrm{HC}), 80 \mathrm{~g} / \mathrm{h}$ de óxidos de nitrogênio $\left(\mathrm{NO}_{\mathrm{x}}\right), 3 \mathrm{~g} / \mathrm{h}$ de material particulado (MP) e $4.000 \mathrm{~g} / \mathrm{h}$ de dióxido de carbono $\left(\mathrm{CO}_{2}\right)$ - esse último sendo o maior responsável pelo "Efeito Estufa". Ao final do ano, cada veículo lançará desnecessariamente na atmosfera cerca de $18 \mathrm{~kg}$ de $\mathrm{CO}, 3 \mathrm{~kg}$ de $\mathrm{HC}, 60 \mathrm{~kg}$ de $\mathrm{NO}_{\mathrm{x}}, 2,2 \mathrm{~kg}$ de $\mathrm{MP}$ e 3 ton de $\mathrm{CO}_{2}$. Se, por exemplo, apenas $10 \%$ da frota a diesel da Região Metropolitana de São Paulo praticarem a marcha lenta nas paradas, seria lançada anualmente na atmosfera a carga adicional de 3,7 mil toneladas de poluentes tóxicos.

Conforme CETESB (2007a) cerca de 90\% da poluição do ar na Região Metropolitana de São Paulo é originária da frota que circula na região que tem registrado aproximadamente 7,3 milhões de veículos, sendo 6,0 milhões de veículos do ciclo Otto (gasolina e álcool), 430 mil veículos a diesel e 870 mil motos, frota esta que representa cerca de 1/5 do total nacional e responde pela emissão de cerca de $97 \%$ das emissões de $\mathrm{CO}, 97 \%$ de $\mathrm{HC}, 96 \% \mathrm{NO}_{\mathrm{x}}, 40 \%$ de $\mathrm{MP}$ e $35 \%$ de $\mathrm{SO}_{\mathrm{x}}$.

Os motores a álcool são mais eficientes que os a gasolina, oferecendo vantagem em relação à emissão de $\mathrm{CO}_{2}$. O álcool apresenta limite de combustão (relação ar/combustível - $\lambda$ até 1,35) maior que a gasolina $(\lambda$ até 1,10$)$, permitindo relações “ $\lambda$ “ mais pobres e mais limpas.

\footnotetext{
${ }^{1}$ CETESBNET - Intranet da Companhia de Tecnologia de Saneamento Ambiental. Notícia exibida em 16 abr 2005.
} 
Alves $\mathrm{Jr}(2007)^{2}$ afirma que, ao substituírem veículos movidos a derivados de petróleo, os veículos a álcool eliminam as emissões de enxofre, atenuando a acidificação da atmosfera, além das emissões de substâncias cancerígenas, como benzeno, olefinas (etileno, propeno e butadieno1,3), formaldeídos e outros componentes policíclicos e aromáticos presentes nos combustíveis fósseis. Veículos a álcool emitem predominantemente o aldeído acético, que tem efeito carcinogênico cerca de 10 vezes inferior ao do benzeno, presente nas emissões dos veículos a diesel e gasolina. Também afirma que por ser o álcool praticamente isento de enxofre, sua adição à gasolina tem a propriedade de reduzir a emissão dos $\mathrm{SO}_{2}$. No que se refere à emissão de partículas finas e inaláveis - PI (com diâmetros inferiores a 2,5 e 10 microns, respectivamente), pelo fato do álcool ser composto por moléculas simples, de baixo peso molecular, e por garantir a queima com menor quantidade de ar, tem emissão desprezível de partículas, reduzindo dessa forma a contribuição dos seus substitutos, os veículos a gasolina, que contribuem com cerca de $10 \%$ de todo material particulado emitido em regiões urbanizadas.

\subsubsection{3- Efeitos sobre os materiais, plantas e animais}

Os materiais são afetados pela poluição de diversas maneiras, tais como: corrosão de estruturas metálicas; Ataque às obras de arte em mármore; Alteração de cor da pintura de carros; Ataque à borracha (cracking, perda de elasticidade, enfraquecimento); Desbotamento de tecidos; Descoloração de tintas, por exemplo.

A presença de umidade e temperatura, juntamente com alguns tipos de poluentes (poluentes ácidos p.e.), formação de ozônio e condições meteorológicas respondem por causarem tais efeitos (SIQUEIRA, 2002).

Atmosfera poluída prejudica o metabolismo dos vegetais uma vez que danifica e destrói sua estrutura, tanto por via aérea tanto pelo solo contaminado. A fauna, apesar de menos sensível que a flora também é afetada. Qualquer alteração na cadeia alimentar (flora ou fauna) pode refletir na existência das espécies.

\footnotetext{
${ }^{2}$ ALVES JR., O M. Veículos à álcool e o meio ambiente. Informação pessoal disponível em fabiof@cetesbnet.sp.gov.br de 10 set 2007
} 
As principais ocorrências são: Alteração da cor das folhas; Alteração do crescimento de vegetais; Penetração de poluentes pelos estômatos; Redução de fotossíntese por sedimentação de partículas nas folhas ou em suspensão na atmosfera; Alteração das condições do solo pela sedimentação ou carreamento pelas chuvas; Morte de vegetais e Morte de animais.

Siqueira (2002) aponta que a penetração de poluentes pelos estômato desencadeia uma série de efeitos nos vegetais:

- Altera as trocas de $\mathrm{CO}_{2}-\mathrm{O}_{2}$, o que pode causar colapso do tecido foliar, clorose ou alteração da cor e do crescimento e produção das plantas;

- $\mathrm{SO}_{2}$ : morte de áreas das folhas, marcas ou clorose;

- Flúor: alteração de crescimento da planta, maturação de frutos precoces;

- Smog $\left(\mathbf{O}_{3}, \mathbf{P A N}, \mathbf{N O}_{\mathrm{x}}\right)$ : lesões em legumes (prateadas) que evoluem para áreas esbranquiçadas.

\subsubsection{4- Efeitos sobre a economia}

É difícil precisar os efeitos da poluição do ar na economia. É sabido que os aumentos das demandas por atendimento ambulatorial e hospitalar decorrentes da poluição atmosférica acarretam impactos econômicos consideráveis aos sistemas de saúde. Além disto, as doenças associadas à poluição do ar podem provocar outros impactos econômicos e sociais, quer pela diminuição da produtividade, faltas escolares e ao trabalho, entre outros motivos.

Já no setor de transporte, IPEA \& ANTP (2006) coloca que o tempo total anual perdido em congestionamento, nas dez cidades pesquisadas, aproxima-se dos 250 milhões de passageiroshora, para automóveis, e 256 milhões de passageiros-hora, para ônibus, significando um gasto adicional de R\$ 194 milhões/ano. Só em São Paulo são gastos, a mais, 105 mil litros de gasolina pelos automóveis e 2,4 mil litros de óleo diesel pelos ônibus, devido aos congestionamentos severos, na hora de pico.

A tabela 2.7 a seguir apresenta um resumo da monetarização anual das deseconomias (milhões de reais) segundo IPEA \& ANTP (2006) para as principais regiões metropolitanas brasileiras. 
Tabela 2.7- Resumo da monetarização anual das deseconomias (milhões de reais)

\begin{tabular}{lrrrrr}
\hline \multicolumn{1}{c}{ Cidade } & Tempo & $\begin{array}{c}\text { Consumo } \\
\text { Combustivel }\end{array}$ & Poluição & Sistema Víário & Total Geral \\
Belo Horizonte & 14,91 & 3,35 & 0,91 & 3,4 & 22,57 \\
Erasília & 1,32 & 0,36 & 0,07 & 6,32 & 8,07 \\
Campinas & 2,13 & 2,41 & 0,62 & 2,67 & 7,83 \\
Curitiba & 1,88 & 1,46 & 0,39 & 0,2 & 3,92 \\
Joấo Pessoa & 0,6 & 0,36 & 0,1 & 1,7 & 2,75 \\
Juiz de Fora & 0,59 & 0,1 & 0,03 & - & 0,71 \\
Porto Alegre & 2,08 & 1,52 & 0,41 & 1,09 & 5,1 \\
Recife & 1,68 & 0,81 & 0,23 & 1,62 & 4,35 \\
Rio de Janeiro & 43,17 & 21,16 & 5,53 & 2,84 & 72,7 \\
Săo Paulo & 125,61 & 115,06 & 28,81 & 76,61 & 346,1 \\
\hline Total & 193,97 & 146,59 & 37,1 & 96,45 & 474,11 \\
\hline
\end{tabular}

*valoresem milhỗes de reais

Fonte: IPEA \& ANTP (2006)

CETESBNET (2005) estima que no Brasil, supondo que os ônibus urbanos permaneçam ligados nas garagens e em terminais por cerca de duas horas por dia (730 h/ano), e sendo o consumo médio em marcha lenta dos veículos novos e regulados de cerca de $1,1 \mathrm{l} / \mathrm{h}$, estima-se um desperdício de, no mínimo, 820 1/ano de óleo diesel, o equivalente a R\$1.400,00/ano por ônibus. Uma frota de cem ônibus joga fora com essa prática, mais de R \$ 140.000,00/ano - valor de um ônibus novo. Se a frota da cidade de São Paulo, de dez mil ônibus, praticarem a marcha lenta irracional, queimará 8,2 milhões de litros de diesel a cada ano - o equivalente a 100 ônibus novos.

\subsubsection{5- Quadro resumo dos efeitos causados pela poluição do ar}

O Relatório de qualidade do Ar de 2007 (CETESB, 2007a) apresenta um resumo das fontes, características e efeitos dos principais poluentes da atmosfera e constitui-se um bom resumo para o capítulo. 


\section{Tabela 2.8- Fontes, características e efeitos dos principais poluentes da atmosfera}

$$
\text { POLUENTE }
$$

CARACTERÍSTICAS

Partículas de material sólido ou líquido que

Partículas Totais ficam suspensos no ar, na forma de poeir

em Suspensão neblina, aerossol, fumaça, fuligem, etc.

Faixa de tamanho $<100$ micra.

Partículas Inaláveis Partículas de material sólido ou líquido que

$\left(\mathrm{MP}_{10}\right)$ Picam susp

e Fumaça neblina, aerossol, fumaça, fuligem, etc. Faixa de tamanho $<10$ micra.

Gás incolor, com forte odor, semelhante ao gás produzido na queima de palitos de fósforos. Pode ser transformado a $\mathrm{SO}_{3}$,

Dióxido de que na presença de vapor de água, passa Enxofre rapidamente a $\mathrm{H}_{2} \mathrm{SO}_{4}$. É um importante

$\left(\mathrm{SO}_{2}\right) \quad$ precursor dos sulfatos, um dos principais componentes das partículas inaláveis.

Gás marrom avermelhado, com odor forte

Dióxido de e muito irritante. Pode levar a formação

Nitrogênio ácido nítrico, nitratos (o qual contribui

$\left(\mathrm{NO}_{2}\right)$ para o aumento das partículas inaláveis na atmosfera) e compostos orgânicos tóxicos.

Monóxido de Gás incolor, inodoro e insípido.

Carbono

\section{Ozônio}

Gás incolor, inodoro nas concentrações

$\left(\mathrm{O}_{3}\right)$ ambientais e o principal componente da névoa fotoquímica.
FONTES PRINCIPAIS

Processos industriais, veículos moto-

rizados (exaustão), poeira de rua

ressuspensa, queima de biomassa.

Fontes naturais: pólen, aerossol

marinho e solo.

Processos de combustão (indústria e Aumento de atendimentos hospitalares e

veículos automotores), aerossol secun- mortes prematuras.

dário (formado na atmosfera).

Processos que utilizam queima de óleo combustível, refinaria de petróleo

veículos a diesel, polpa e papel.

tróleo,

Desconforto na respiração, doenças

respiratórias, agravamento de doenças

respiratórias e cardiovasculares já

existentes. Pessoas com asma, doenças

crônicas de coração e pulmão são mais

sensíveis ao $\mathrm{SO}_{2}$

Processos de combustão envolvendo veículos automotores, processos industriais, usinas térmicas que

utilizam óleo ou gás, incinerações.

Combustão incompleta em veículos

automotores.

Não é emitido diretamente à atmosfera É produzido fotoquimicamente pela radiação solar sobre os óxidos de nitrogênio e compostos orgânicos voláteis.

Aumento da sensibilidade à asma e à bronquite, abaixar a resistência às

infecções respiratórias.

Altos níveis de CO estão associados a prejuízo dos reflexos, da capacidade de estimar intervalos de tempo, no aprendizado, de trabalho e visual.

Irritação nos olhos e vias respiratórias, diminuição da capacidade pulmonar. Exposição a altas concentrações pode peito, tosse e chiado na respiração.
EFEITOS GERAIS AO MEIO AMBIENTE

Danos à vegetação, deterioração da visibilidade e contaminação do solo.

Danos à vegetação, deterioração da visibilidade e contaminação do solo.

Pode levar à formação de chuva ácida causar corrosão aos materiais e danos à vegetação: folhas e colheitas.

Pode levar à formação de chuva ácida danos à vegetação e à colheita.

Danos às colheitas, à vegetação natural, resultar em sensações de aperto no

$\mathrm{O}_{3}$ tem sido associado ao aumento de admissões hospitalares. 


\section{3- Dinâmica da atmosfera}

Esta seção é apresentada àqueles leitores que, não familiares com os termos ambientais e com conceitos de química e física, relacionados a atmosfera requeiram um pouco mais de embasamento teórico, de forma a conseguir analisar o que os Decretos Estaduais $\mathrm{n}^{\circ} 48.523 / 04, \mathrm{n}^{\circ} 50.753 / 06$ e $\mathrm{n}^{\circ} 52.469 / 07$ se propõem a alterar no licenciamento ambiental do Estado de São Paulo.

Assim, para se entender este meio é necessário saber determiná-lo, conhecendo suas características e inter-relação com os outros biomas, a dinâmica dos poluentes na atmosfera, fontes e sumidouros entre outros. Assim a abordagem desta seção será feita apontando as características físicas e químicas da atmosfera, bem como a identificação de fontes e poluentes.

\subsection{1- Física da atmosfera}

A atmosfera da Terra é composta por uma série de gases e vapor d'água, cuja abundância é controlada pela escala de tempo geológico pela biosfera, nos chamados ciclos biogeoquímicos. Assim o ar que respiramos hoje nem sempre foi o mesmo que circundou a Terra e provavelmente não será o mesmo em tempos futuros.

A figura 2.1 a seguir mostrar que a atmosfera apresenta variação de temperatura e composição que variam de acordo com a altura em relação à superfície terreste. Divide a atmosfera segundo a estrutura da temperatura de suas camadas (à esquerda) e segundo sua composição (à direita), as mudanças na densidade molecular aparente do ar (Md) de acordo com a composição da atmosfera são mostradas no centro. 


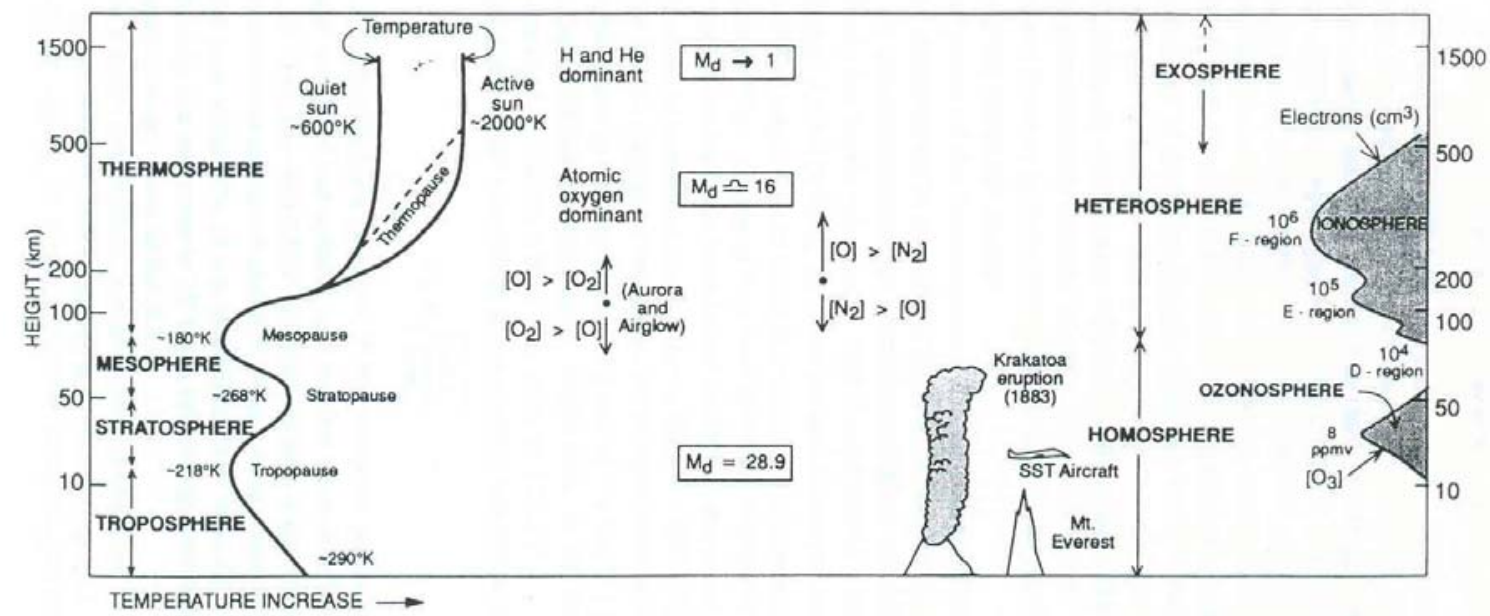

Figure 3.1. Two ways of dividing the atmosphere: by temperature structure (left side) and by composition (right side). The change in the apparent molecular weight of air $\left(M_{d}\right)$ due to the changing composition of the atmosphere with height is shown in the center.

Figura 2.1- Variação de composição e temperatura da atmosfera em função da altura da superfície terreste

Fonte: HOBBS (2000)

Percebe-se que os gases e vapores de maior densidade molecular (Md) concentram-se próximos à superfície da Terra, na camada chamada troposfera, onde se aplicam os conceitos de gestão de bacias aéreas e cuja composição e fenômenos meteorológicos afetam mais diretamente a qualidade de vida de seres vivos e materiais.

A troposfera é a porção mais próxima à superfície terrestre, com até $10 \mathrm{~km}$ de altitude e pressão superior a $200 \mathrm{mb}$ e temperatura que varia de 40 a $-60^{\circ} \mathrm{C}$ (baixa troposfera), onde localiza-se a camada de mistura. O conhecimento da camada de mistura, porção de ar com altura da superfície de até $3 \mathrm{~km}$ é importante pois delimita a região onde quase que a totalidade das reações físico-químicas na atmosfera se processam.

$\mathrm{O}$ ar é usado em processos metabólicos (respiração, fotossíntese, nitrificação), na propagação de ondas (comunicação), em processos de combustão e secagem (industrial e natural), geração de energia (aerogeradores), além de servir de meio receptor e transportador de espécies químicas e biológicas nele emitidas.

Brasseur (1999) apresenta na figura 2.2 a constituição dos gases da atmosfera de acordo com a altitude, variando da superfície até $120 \mathrm{~km}$. 


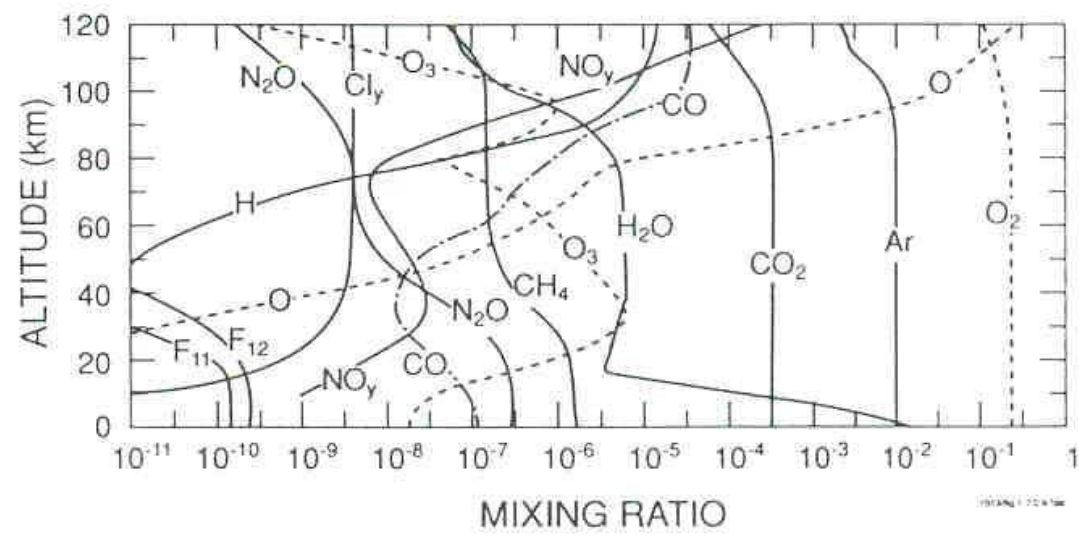

Figura 2.2- Distribuição vertical típica da concentração dos constituintes químicos da atmosfera

Fonte: BRASSEUR (1999)

A concentração dos gases geralmente decresce ou se mantêm com o aumento da altitude. Casos como o do elemento Hidrogênio $(\mathrm{H})$ e do elemento Oxigênio $(\mathrm{O})$ apresentam comportamento inverso, tendo suas concentrações aumentadas com a elevação da altitude.

Sendo a troposfera a porção da atmosfera onde se concentram os gases usados na respiração dos seres humanos e plantas e onde ocorrem os fenômenos meteorológicos mais significativos serão objeto de maior atenção.

Hobbs (2000) apresenta na tabela 2.9 a concentração padrão adotada para a concentração de gases na constituição da atmosfera limpa (não urbana), muito embora sua composição esteja diretamente relacionada à vários fatores locais, como: a influência da temperatura, da pressão, a proximidade de corpos d'água, rios, reservatórios, lagos, existência de fontes de emissão de poluentes (fixas, móveis, naturais, antropogênicas e biogênicas), condições de dispersão local, altitude e outros. Em suma, as condições climatológicas e antropogências definem a característica do ar de uma dada região. 
Tabela 2.9- Composição do ar troposférico limpo (não urbano)

\begin{tabular}{|c|c|c|}
\hline Chemical Species & Concentration & Source \\
\hline \multicolumn{3}{|l|}{ A. Major and Minor Gases } \\
\hline Nitrogen $\left(\mathrm{N}_{2}\right)$ & $\begin{array}{l}78.08 \% \\
(780,840 \mathrm{ppmv})\end{array}$ & Volcanic, biogenic \\
\hline Oxygen $\left(\mathrm{O}_{2}\right)$ & $\begin{array}{l}20.95 \% \\
(209,460 \mathrm{ppmv})\end{array}$ & Biogenic \\
\hline Argon (Ar) & $0.93 \%(9,340 \mathrm{ppmv})$ & Radiogenic \\
\hline Water vapor $\left(\mathrm{H}_{2} \mathrm{O}\right)$ & $\begin{array}{l}\text { Variable - up to } 4 \% \\
\text { (40,000 ppmv) }\end{array}$ & Volcanic, evaporation \\
\hline Carbon dioxide $\left(\mathrm{CO}_{2}\right)$ & $0.036 \%$ (355 ppmv) & $\begin{array}{l}\text { Volcanic, biogenic, } \\
\text { anthropogenic }\end{array}$ \\
\hline \multicolumn{3}{|l|}{ B. Trace Constituents } \\
\hline & $0-100 \mathrm{ppby}$ & Photochemical \\
\hline $\begin{array}{l}\text { Ozone }\left(O_{1}\right) \\
\text { Atomic oxygen }(O)\end{array}$ & $\begin{array}{l}0-100 \mathrm{ppbv}^{-1} \\
0-10^{\prime} \mathrm{cm}^{-3}\end{array}$ & $\begin{array}{l}\text { Photochemical } \\
\text { Photochemical }\end{array}$ \\
\hline $\begin{array}{l}\text { Atomic oxygen }(\mathrm{O}) \\
\text { (ground state) }\end{array}$ & & \\
\hline $\begin{array}{l}\text { Atomic oxygen }(\mathrm{O}) \\
\left(\mathrm{O}^{*}-\text { excited state }\right)\end{array}$ & $0-10^{-2} \mathrm{~cm}^{-3}$ & Photochemical \\
\hline \multicolumn{3}{|l|}{ 2. Hydrogen Species } \\
\hline Hydrogen $\left(\mathrm{H}_{2}\right)$ & $560 \mathrm{ppbv}$ & Photochemical, biogenic \\
\hline $\begin{array}{l}\text { Hydrogen peroxide } \\
\left(\mathrm{H}_{3} \mathrm{O}_{2}\right)\end{array}$ & $10^{\circ} \mathrm{cm}^{-3}$ & Photochemical \\
\hline $\begin{array}{l}\text { Hydroperoxyl radical } \\
\left(\mathrm{HO}_{2}\right)\end{array}$ & $0-10^{8} \mathrm{~cm}^{-3}$ & Photochemical \\
\hline Hydroxyl radical $(\mathrm{OH})$ & $0-10^{\prime} \mathrm{cm}^{-3}$ & Photochemical \\
\hline Atomic hydrogen $(\mathrm{H})$ & $0-1 \mathrm{~cm}^{-3}$ & Photochemical \\
\hline \multicolumn{3}{|l|}{ 3. Nitrogen Species } \\
\hline Nitrous oxide $\left(\mathrm{N}_{2} \mathrm{O}\right)$ & $310 \mathrm{ppbv}$ & Biogenic, anthropogenic \\
\hline Nitric acid (HNO,) & $0-100$ pptv & Photochemical \\
\hline Ammonia $\left(\mathrm{NH}_{3}\right)$ & $0-0.5 \mathrm{ppbv}$ & Biogenic, anthropogenic \\
\hline $\begin{array}{l}\text { Hydrogen cyanide } \\
\text { (HCN) }\end{array}$ & $-200 \mathrm{pptv}$ & Anthropogenic (?) \\
\hline Nitrogen dioxide $\left(\mathrm{NO}_{2}\right)$ & $0-300 p p t v$ & Photochemical \\
\hline Nitric oxide (NO) & 0-300pptv & $\begin{array}{l}\text { Anthropogenic, biogenic, } \\
\text { lightning. } \\
\text { photochemical }\end{array}$ \\
\hline Nitrogen trioxide $(\mathrm{NO})$, & $0-100 \mathrm{pptv}$ & Photochemical \\
\hline $\begin{array}{l}\text { Peroxyacetyl nitrate } \\
(\mathrm{PAN})\left(\mathrm{CH}_{3} \mathrm{CO}_{3} \mathrm{NO}_{2}\right)\end{array}$ & $0-50 \mathrm{pptv}$ & Photochemical \\
\hline $\begin{array}{l}\text { Dinitrogen pentoxide } \\
\left(\mathrm{N}_{2} \mathrm{O}_{3}\right)\end{array}$ & $0-1$ pptv & Photochemical \\
\hline Pernitric acid $\left(\mathrm{HO}_{2} \mathrm{NO}_{2}\right)$ & $0-0.5 \mathrm{pptv}$ & Photochemical \\
\hline Nitrous acid $\left(\mathrm{HNO}_{2}\right)$ & $0-0.1 \mathrm{pptv}$ & Photochemical \\
\hline \multicolumn{3}{|l|}{ Nitrogen aerosols: } \\
\hline $\begin{array}{l}\text { Ammonium Nitrate } \\
\left(\mathrm{NH}_{4} \mathrm{NO}_{3}\right)\end{array}$ & $\sim 10 \mathrm{pptv}$ & Photochemical \\
\hline $\begin{array}{l}\text { Ammonium chloride } \\
\left(\mathrm{NH}_{4} \mathrm{Cl}\right)\end{array}$ & $-0.1 \mathrm{pptv}$ & Photochemiçal \\
\hline $\begin{array}{l}\text { Ammonium sulfate } \\
\left(\left(\mathrm{NH}_{4}\right)_{2} \mathrm{SO}_{4}\right)\end{array}$ & $-0.1 \mathrm{pptv}$ & Photochemical \\
\hline
\end{tabular}

\begin{tabular}{|c|c|c|}
\hline Chemical Species & Concentration $^{b}$ & Source \\
\hline \multicolumn{3}{|l|}{ 4. Carbon Species } \\
\hline \multirow{3}{*}{$\begin{array}{l}\text { Methane }\left(\mathrm{CH}_{4}\right) \\
\text { Carbon monoxide }(\mathrm{CO})\end{array}$} & $1.7 \mathrm{ppmv}$ & \multirow{3}{*}{$\begin{array}{l}\text { Anthropogenic, biogenic, } \\
\text { photochemical }\end{array}$} \\
\hline & $\begin{array}{l}\text { 70-200ppbv } \\
\text { (N hemisphere) }\end{array}$ & \\
\hline & $\begin{array}{l}\text { 40-60 ppbv } \\
\text { (S. hemisphere) }\end{array}$ & \\
\hline Formaldehyde $\left(\mathrm{CH}_{2} \mathrm{O}\right)$ & $0.1 \mathrm{ppbv}$ & Photochemical \\
\hline $\begin{array}{l}\text { Methyl hydroperoxide } \\
\text { radical }(\mathrm{CH}, \mathrm{OOH})\end{array}$ & $0-10^{11} \mathrm{~cm}^{-3}$ & Photochemical \\
\hline $\begin{array}{l}\text { Methylperoxy radical } \\
\left(\mathrm{CH}, \mathrm{O}_{2}\right)\end{array}$ & $0-10^{8} \mathrm{~cm}^{-3}$ & Photochemical \\
\hline Methyl radical $\left(\mathrm{CH}_{3}\right)$ & $0-10^{-1} \mathrm{~cm}^{-3}$ & Photochemical \\
\hline \multirow{2}{*}{$\begin{array}{l}\text { 5. Sulfur Species } \\
\text { Carbonyl sulfide (COS) }\end{array}$} & & \\
\hline & $0.05 \mathrm{ppbv}$ & $\begin{array}{l}\text { Voleanic, anthropogenic, } \\
\text { biogenic }\end{array}$ \\
\hline $\begin{array}{l}\text { Dimethyl sulfide (DMS) } \\
\left(\left(\mathrm{CH}_{3}\right)_{2} \mathrm{~S}\right)\end{array}$ & 70-200pptv & Biogenic \\
\hline Hydrogen sulfide $\left(\mathrm{H}_{2} \mathrm{~S}\right)$ & $0-0.5 \mathrm{ppbv}$ & Biogenic, anthropogenic \\
\hline Sulfur dioxide $\left(\mathrm{SO}_{2}\right)$ & $0.2 \mathrm{pp}$ & $\begin{array}{l}\text { Volcanic, anthropogenic, } \\
\text { photochemical }\end{array}$ \\
\hline $\begin{array}{l}\text { Dimethyl disulfide } \\
\left(\left(\mathrm{CH}_{3}\right)_{2} \mathrm{~S}_{2}\right)\end{array}$ & 5-10pptv & Biogenic \\
\hline Carbon disulfide $\left(\mathrm{CS}_{2}\right)$ & 5-10pptv & $\begin{array}{l}\text { Volcanic, anthropogenic, } \\
\text { biogenic }\end{array}$ \\
\hline Sulfuric acid $\left(\mathrm{H}_{2} \mathrm{SO}_{4}\right)$ & $0-20 \mathrm{pptv}$ & Photochemical \\
\hline Sulfurous acid $\left(\mathrm{H}_{2} \mathrm{SO}_{3}\right)$ & $0-20$ pptv & Photochemical \\
\hline Sulfur monoxide (SO) & $0-10^{5} \mathrm{~cm}^{-3}$ & Photochemical \\
\hline $\begin{array}{l}\text { Thiohydroxyl radical } \\
\text { (HS) }\end{array}$ & $0-1 \mathrm{~cm}^{-3}$ & Photochemical \\
\hline $\begin{array}{l}\text { (HS) } \\
\text { Sulfur trioxide }\left(\mathrm{SO}_{3}\right)\end{array}$ & $0-10^{-2} \mathrm{~cm}^{-3}$ & Photochemical \\
\hline \multicolumn{3}{|l|}{$\begin{array}{l}\text { Sulfur trioxide }\left(\mathrm{SO}_{3}\right) \\
\text { 6. Halogen species }\end{array}$} \\
\hline Hydrogen chloride $(\mathrm{HCl})$ & $1 \mathrm{ppbv}$ & Sea salt, volcanic \\
\hline Methyl chloride $(\mathrm{CH}, \mathrm{Cl})$ & $0.5 \mathrm{ppbv}$ & Biogenic, anthropogenic \\
\hline Methyl bromide $\left(\mathrm{CH}_{3} \mathrm{Br}\right)$ & $10 \mathrm{pptv}$ & Biogenic, anthropogenic \\
\hline Methyl iodide $\left(\mathrm{CH}_{3} \mathrm{I}\right)$ & $1 \mathrm{pptv}$ & Biogenic \\
\hline \multicolumn{3}{|c|}{ 7. Noble Gases (chemically inert) } \\
\hline $\mathrm{Neon}(\mathrm{Ne})$ & $18 \mathrm{ppmv}$ & Volcanic (?) \\
\hline Helium (He) & $5.2 \mathrm{ppmv}$ & Radiogenic \\
\hline Krypton (Kr) & $1 \mathrm{ppmv}$ & Radiogenic \\
\hline Xenon (Xe) & $90 \mathrm{ppbv}$ & Radiogenic \\
\hline \multicolumn{3}{|c|}{$\begin{array}{l}\text { Adapted from J. S. Levine in Global Ecology, Eds. M. B. Rambler et al., Academic } \\
\text { Press, New York, 1989, p. } 53 \text {, } \\
\text { "Typical values at } 1 \text { atm are given; many of the trace gases have highly variable con- } \\
\text { centrations. In addition to percentage by volume, the units are: } \\
\text { parts per million by volume (ppmv) }=10^{-4} \\
\text { parts per billion by volume (ppbv) }=10^{-5} \\
\text { parts per trillion by volume }(\mathrm{pptv})=10^{-12} \\
\text { number density of molecules at the surface }\left(\mathrm{cm}^{-1}\right) \text {. }\end{array}$} \\
\hline
\end{tabular}

Fonte: HOBBS (2000)

Os processos físicos são muito importantes, assim como os processos químicos para o resultado final da composição do ar num dado local.

O transporte de substâncias na camada de mistura obedece às leis da física e pode ser horizontal e vertical. No transporte horizontal (troposfera-estratosfera quem mais nos interessa) ocorrem principalmente devido às características físico-químicas das substâncias analisadas. Na maioria dos casos não representam fontes e sumidouros significativos, não afetando a composição básica destas camadas. Tal fato é comprovado através da análise dos gases constituintes das camadas da atmosfera, como a presença de gases mais densos (Densidade molecular: $\mathrm{Md}=28,9)$ na troposfera, predominância de oxigênio $(\mathrm{Md}=16)$ na parte superior da mesosfera e abundância de hidrogênio e hélio $(\mathrm{Md}=1)$ na termosfera.

No transporte vertical promove-se a dispersão e diluição dos poluentes. A ação da força de coriólis, resultante do movimento de rotação da Terra ajuda no transporte destes poluentes. 
A circulação Hadley também contribue uma vez que nos pólos a temperatura é mais baixa do que na região da linha do equador, fazendo com que o ar ao longo do globo circule verticalmente e horizontalmente.

JACOB (1999) mostra na figura 2.3 a circulação geral com pressão ao nível do mar e padrão geral de ventos de superfície ao redor do globo de Janeiro a Julho.

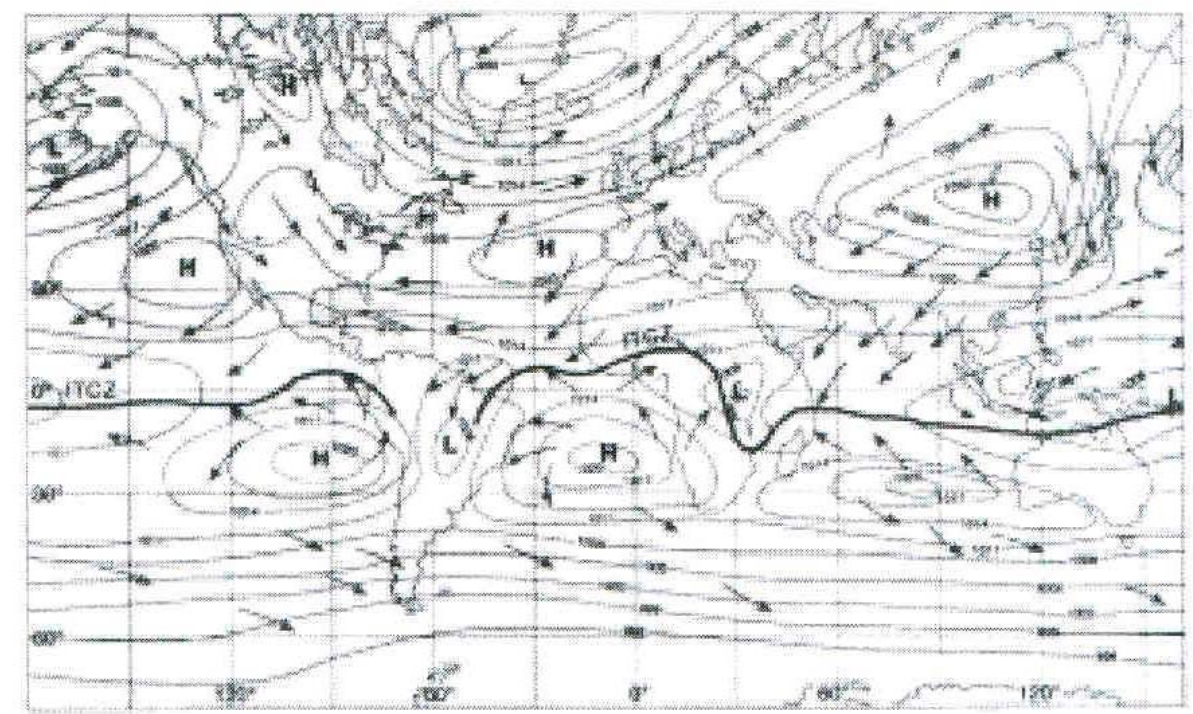

ixis inewer

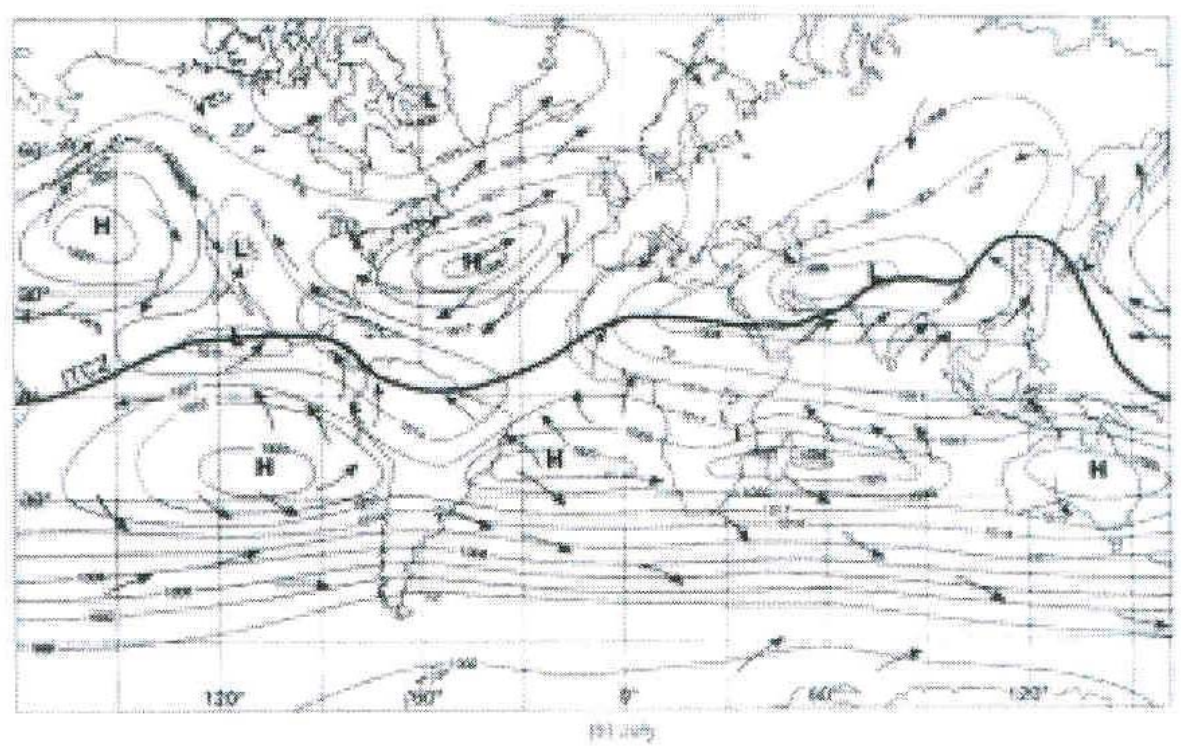

Figura 2.3- Variação da pressão atmosférica e vento superficial (Janeiro a Julho) Fonte: JACOB (1999)

O comportamento de um determinado poluente na atmosfera é determinado também por questões de pressão e temperatura que são traduzidas pelo conceito de estabilidade da atmosfera. Insolação, proximidade de reservatórios d'água e outros fatores físicos 
influenciam diretamente na estabilidade da atmosfera que, para efeito de modelagem matemática e cálculo de concentração em modelos de dispersão atmosférica é introduzido comumente nos modelos através dos seguintes parâmetros:

- Classes de estabilidade (Estability class): varia de A até F (estável-instável) e estima a mistura (dispersão) da pluma, são as classes de turbulência;

- Camada de mistura (Mix Height): para calcular a barreira física de dispersão na atmosfera;

- Quebra de pluma (Building Downwash): para calcular a influência de prédios e formação de vótex;

- Deposição (Deposition): Seca ou úmida que ocorre na pluma em virtude do diâmetro das partículas e sua densidade, em ausência ou presença de umidade;

- Dados Meteorológicos (Meteorological Datas): Direção do vento, velocidade, insolação, pressão e outros para cálculo da dispersão.

O comportamento da massa de ar, e por conseguinte do poluente nela encontrado obedece a equação da continuidade e o regime de trabalho do fluido sendo este laminar ou turbulento, definidos pelo número de Reynolds através da sua viscosidade cinemática.

Para a definição da turbulência em fluidos newtonianos (ar) parâmetros de distância e velocidade do ar são necessários pois na maioria dos modelos utilizam-se a relação entre turbulência térmica e turbulência mecânica, além do conceito de rugosidade superficial, quando define-se o tipo de terreno (rural, urbano, etc).

A incidência de radiação solar em vários comprimentos de onda $(h v)$ que chegam à Terra também tem bastante importância, uma vez que atuam decisivamente na formação de diversos compostos químicos e também na reação de fotossíntese e processos fotoquímicos, além de serem responsável pelo aquecimento da superfície terrestre.

Na figura 2.4, Sienfeld (2006) apresenta o balanço global da radiação que incide na Terra. Do total de $342 \mathrm{Wm}^{-2}$ de radiação solar incidente, $168 \mathrm{Wm}^{-2}$ é absorvida pela superfície. Esta energia retorna à atmosfera em forma de calor sensível e calor latente no vapor e radiação térmica infravermelha. A maior parte da radiação é absorvida pela atmosfera que, 
emite radiação tanto reemitindo-a para o espaço novamente quanto retornando para a troposfera.

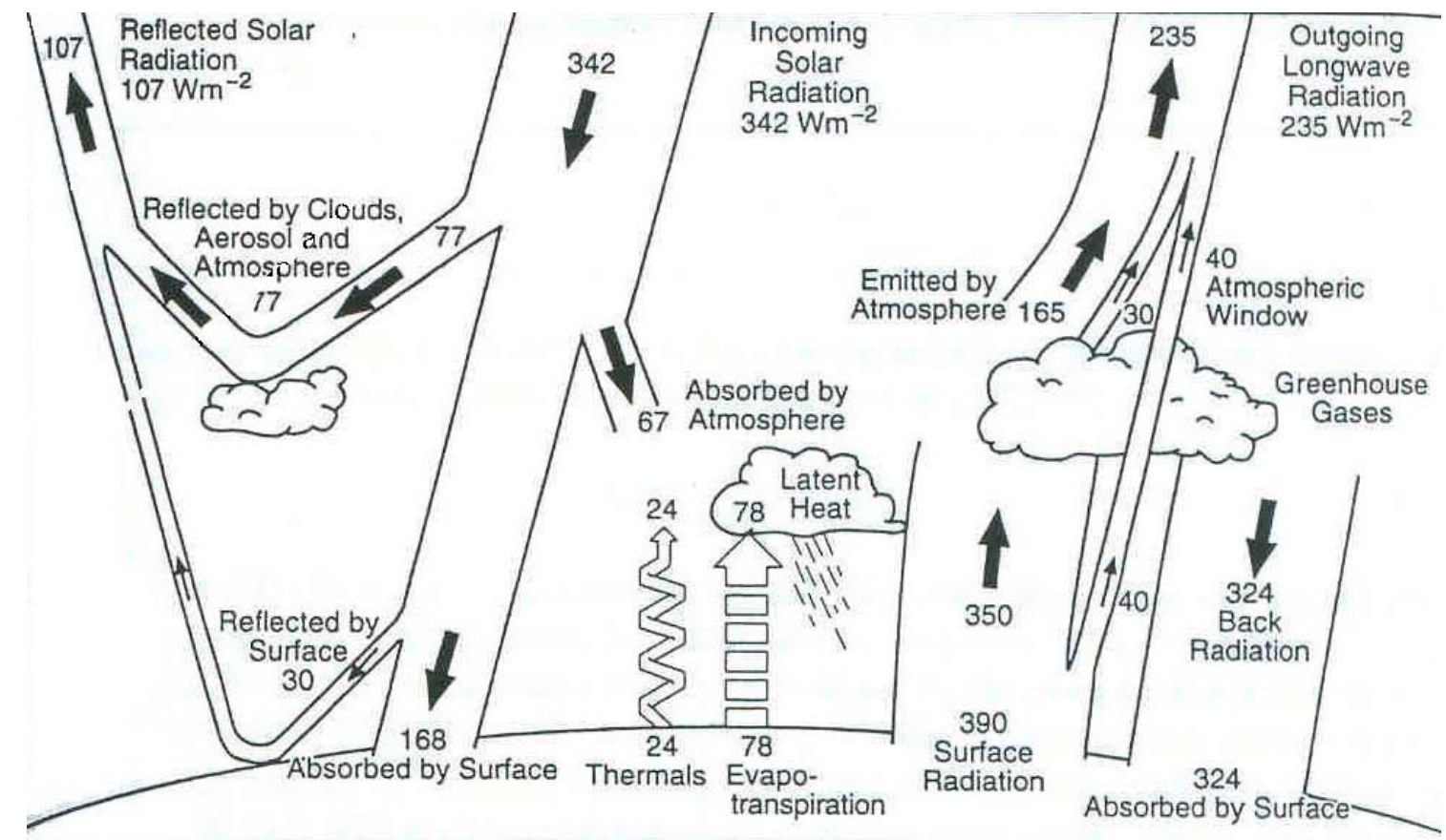

\section{Figura 2.4- Balanço energético global da Terra $\left(\mathrm{Wm}^{-2}\right)$}

Fonte: SIENFELD (2006)

A atenuação da radiação solar pelos gases e vapores a ser observada na próxima seção (química da troposfera) é importante para o entendimento da formação do ozônio troposférico e de outras reações químicas na atmosfera.

\subsubsection{1- Poluentes atmosféricos e fontes de emissão}

Como vimos anteriormente a composição da atmosfera é muito variável e dependente de vários fatores. Como definir então o que é considerado poluente?

Um bom parâmetro é a definição legal expressa no próprio Decreto Estadual nº.468/76:

Artigo $3^{\circ}$ - Considera-se poluente toda e qualquer forma de matéria ou energia lançada ou liberada nas águas, no ar ou no solo:

I - com intensidade, em quantidade e de concentração, em desacordo com os padrões de emissão estabelecidos neste Regulamento e normas dele decorrentes;

II - com características e condições de lançamento ou liberação, em desacordo com os padrões de condicionamento e projeto estabelecidos nas mesmas prescrições;

III - por fontes de poluição com características de localização e utilização em desacordo com os referidos padrões de condicionamento e projeto;

IV- com intensidade, em quantidade e de concentração ou com características que, direta ou indiretamente, tornem ou possam tornar ultrapassáveis os padrões de qualidade do meio-ambiente estabelecidos neste Regulamento e normas dele decorrentes; 
V - que, independentemente de estarem enquadrados nos incisos anteriores, tornem ou possam tornar as águas, o ar ou o solo impróprios, nocivos ou ofensivos à saúde, inconvenientes ao bem-estar público; danosos aos materiais, à fauna e à flora; prejudiciais à segurança, ao uso e gozo da propriedade, bem como às atividades normais da comunidade.

Para poluentes atmosféricos a Resolução CONAMA nº3 de 28 de junho de 1990 elenca, com vistas ao estabelecimento de Padrões de Qualidade do Ar, os seguintes poluentes e seus padrões primários e secundários:

Art. $3^{\circ}$ - Ficam estabelecidos os seguintes Padrões de Qualidade do Ar:

I - Partículas Totais em Suspensão

a) Padrão Primário

1 - concentração média geométrica anual de 80 (oitenta) microgramas por metro cúbico de ar.

2- concentração média de 24 (vinte e quatro) horas de 240 (duzentos e quarenta) microgramas por metro cúbico de ar, que não deve ser excedida mais de uma vez por ano.

b) Padrão Secundário

1 - concentração média geométrica anual de 60 (sessenta) microgramas por metro cúbico de ar.

2 - concentração média de 24 (vinte e quatro) horas de 150 (cento e cinqüenta) microgramas por metro cúbico de ar, que não deve ser excedida mais de uma vez por ano.

II - Fumaça

a) Padrão Primário

1 - concentração média aritmética anual de 60 (sessenta) microgramas por metro cúbico de ar.

2 - concentração média de 24 (vinte e quatro) horas de 150 (cento e cinqüenta) microgramas por metro cúbico de ar, que não deve ser excedida mais de uma vez por ano.

b) Padrão Secundário

1 - concentração média aritmética anual de 40 (quarenta) microgramas por metro cúbico de ar.

2 - concentração média de 24 (vinte e quatro) horas de 100 (cem) microgramas por metro cúbico de ar, que não deve ser excedida mais de uma vez por ano.

III - Partículas Inaláveis

a) Padrão Primário e Secundário

1 - concentração média aritmética anual de 50 (cinqüenta) microgramas por metro cúbico de ar.

2 - concentração média de 24 (vinte e quatro) horas de 150 (cento e cinqüenta) microgramas por metro cúbico de ar, que não deve ser excedida mais de uma vez por ano.

IV - Dióxido de Enxofre

a) Padrão Primário

1 - concentração média aritmética anual de 80 (oitenta) microgramas por metro cúbico de ar.

2 - concentração média de 24 (vinte e quatro) horas de 365 (trezentos e sessenta e cinco) microgramas por metro cúbico de ar, que não deve ser excedida mais de uma vez por ano.

b) Padrão Secundário

1 - concentração média aritmética anual de 40 (quarenta) microgramas por metro cúbico de ar.

2 - concentração média de 24 (vinte e quatro) horas de 100 (cem) microgramas por metro cúbico de ar, que não deve ser excedida mais de uma vez por ano.

$\checkmark$ - Monóxido de Carbono

a) Padrão Primário e Secundário

1 - concentração média de 8 (oito) horas de 10.000 (dez mil) microgramas por metro cúbico de ar (9ppm), que não deve ser excedida mais de uma vez por ano.

2 - concentração média de 1 (uma) hora de 40.000 (quarenta mil) microgramas por metro cúbico de ar (35 ppm), que não deve ser excedida mais de uma vez por ano.

VI - Ozônio

a) Padrão Primário e Secundário 
1 - concentração média de 1 (uma) hora de 160 (cento e sessenta) microgramas por metro cúbico de ar, que não deve ser excedida mais de uma vez por ano.

VII - Dióxido de Nitrogênio

a) Padrão Primário

1 - concentração média aritmética anual de 100 (cem) microgramas por metro cúbico de ar.

2 - concentração média de 1 (uma) hora de 320 (trezentos e vinte) microgramas por metro cúbico de ar.

b) Padrão Secundário

1 - concentração média aritmética anual de 100 (cem) microgramas por metro cúbico de ar.

2 - concentração média de 1 (uma) hora de 190 (cento e noventa) microgramas por metro cúbico de ar.

Assim o nível de poluição do ar é medido pela quantificação das substâncias poluentes presentes neste ar (através do grau de exposição dos receptores) que, pela sua concentração possa torná-lo impróprio, nocivo ou ofensivo à saúde, inconveniente ao bem-estar público, danoso aos materiais, à fauna e à flora ou prejudicial à segurança, ao uso e gozo da propriedade e às atividades normais da comunidade.

Assunção \& Pesquero (2006) colocam que os padrões primários de qualidade do ar representam as concentrações de poluentes que, ultrapassadas poderão afetar a saúde da população e podem ser entendidos como níveis máximos toleráveis de concentração de poluentes atmosféricos, constituindo-se assim como metas de curto e médio prazo. Os padrões secundários de qualidade do ar são as concentrações de poluentes atmosféricos abaixo das quais se prevê o mínimo efeito adverso sobre o bem estar da população, assim como o mínimo dano à fauna e flora, aos materiais e ao meio ambiente em geral. São considerados níveis desejados de concentração de poluentes, constituindo-se em metas de longo prazo.

Para Sienfeld (2006) uma condição de ar poluído deve ser definida como uma situação na qual substâncias que resultem de atividades antropogênicas estão presentes em concentração suficientemente elevada acima dos níveis normais do ambiente para produzir efeitos indesejáveis aos humanos, animais, vegetação ou materiais. Esta definição pode incluir qualquer substância, nociva ou benigna; tendo estas, entretanto, implicações de efeitos indesejáveis.

Os poluentes atmosféricos podem ser classificados quanto: forma física, origem, ocorrência e outros (tóxicos, persistentes, etc). Para as fontes de emissão, novamente a definição expressa no próprio Decreto Estadual n ${ }^{\circ} 8.468 / 76$ faz-se presente: 
(1) Art. $4^{\circ}$ - São consideradas fontes de poluição todas as obras, atividades, instalações, empreendimentos, processos, dispositivos, móveis ou imóveis, ou meios de transportes que, direta ou indiretamente, causem ou possa causar poluição ao meio ambiente.

Parágrafo único - Para efeito da aplicação deste artigo, entende-se como fontes móveis todos os veículos automotores, embarcações e assemelhados, e como fontes estacionárias, todas as demais.

(1) Com redação dada pelo Decreto $n^{\circ} 39.551$, de 18.11 .94

As fontes de emissão de poluentes atmosféricos são provenientes de emissão de fontes estacionárias (indústrias), móveis (automóveis e veículos pesados), naturais, antropogênicas e biogênicas.

Os poluentes atmosféricos regulamentados e objeto dos Decretos Estaduais $\mathrm{n}^{\circ} 48.523 / 04$, n50.753/06 e n52.469/07 são poluentes específicos: material particulado (MP), óxidos de nitrogênio $\left(\mathrm{NO}_{\mathrm{x}}\right)$, compostos orgânicos voláteis, exceto metano $\left(\mathrm{COVs}\right.$, não- $\left.\mathrm{CH}_{4}\right)$, óxidos de enxofre $\left(\mathrm{SO}_{\mathrm{x}}\right)$, e monóxido de carbono $(\mathrm{CO})$. Já as fontes de emissão são todas aquelas presentes no território do Estado de São Paulo.

Para fins desta dissertação o ozônio troposférico será o poluente estudado, fazendo-se necessário conhecer seus precursores $\left(\mathrm{NO}_{\mathrm{x}}\right.$ e COVs exceto $\left.\mathrm{CH}_{4}\right)$, uma fez que o este é formado à partir da reação dos precursores em presença de radiação $h v$ de comprimento de onda específico (por volta de $320 \mathrm{~nm}$ ). Tal poluente foi adotado por ser atualmente o principal contribuinte da má qualidade do ar em quase todas as regiões do Estado de São Paulo e será melhor analisado.

Nesta seção seguem-se os conceitos e informações de formação e emissão dos poluentes precursores do ozônio troposférico, quais sejam:

\subsubsection{1- Óxidos de nitrogênio}

Os óxidos de nitrogênio $\left(\mathrm{NO}, \mathrm{NO}_{2}, \mathrm{~N}_{2} \mathrm{O}, \mathrm{N}_{2} \mathrm{O}_{4}\right.$ ) também conhecidos por $\mathrm{NO}_{\mathrm{x}}$ são substâncias formadoras do ozônio troposférico e que têm, como principal mecanismo de formação os processos:

1- Térmico: $\mathrm{N}_{2}$ ar + Oxigênio.

2- Combustível: $\mathrm{N}_{2}$ comb + Oxigênio.

3- Ativo: $\mathrm{N}_{2}$ ar + Radicais Hidrocarbônicos. 
Já os principais processos formadores destas substâncias estão:

\section{1-Nas reações de combustão industrial e fonte móvel}

$\mathrm{C}+\mathrm{H}+\mathrm{S}+$ elementos não combustíveis $+\left(\mathrm{O}_{2}+3,76 \mathrm{~N}_{2}\right) \rightarrow\left(\mathrm{CO}_{2}+\mathrm{CO}\right)+\mathrm{H}_{2} \mathrm{O}+\left(\mathrm{SO}_{3}+\mathrm{SO}_{2}\right)+$ $\left(\mathrm{N}_{2}+\mathrm{NO}_{\mathrm{x}}\right)+\mathrm{O}_{2}+\mathrm{HC}$ s + Material Particulado (cinza + combustível não queimado).

\section{2- Nas operações de processos industriais}

Processos químicos que apresentem como subprodutos ou resíduos de $\mathrm{NO}_{\mathrm{x}}$.

\subsubsection{2- Compostos orgânicos voláteis- COVs exceto metano.}

Os compostos orgânicos voláteis são todos os hidrocarbonetos de cadeia aberta ou fechada, aromáticos ou não e que em temperatura ambiente ou com aquecimento não se oxidam à $\mathrm{CO}_{2}$, volatilizando-se e sendo emitidos para a atmosfera.

Já os principais processos formadores destas substâncias estão:

\section{1-Nas emissões biogênicas}

Emissão foliar de várias espécies de vegetais, nas plantações, madeira, oceanos (em função da radiação e temperatura ambiente). Exemplos de COVs emitidos por vegetais são os terpenos, isoprenos, $\alpha$ e $\beta$ pineros, ocimeno, $d$-limoneno e outros.

\section{2- Nas operações de processos industriais}

Processos químicos que apresentem emissões evaporativas e fugitivas de orgânicos voláteis. São hidrocarbonetos de vários pesos moleculares.

\section{3- Nos processos de estocagem e transferência de hidrocarbonetos}

Processos de armazenamento de combustíveis em tanques, transferências de combustíveis e postos de abastecimento de veículos automotores, postos flutuantes, similares e outros.

\subsection{2- Química da troposfera}

A qualidade do ar na troposfera é dada pela somatória de poluentes emitidos, as condições físicas de dispersão e interação entre as espécies presentes. Os processos químicos que alteram a composição da atmosfera local são inúmeros. $\mathrm{O}$ tempo de residência dos gases na atmosfera, tempo de meia vida, velocidade e ordem das reações entre os componentes nela presentes, nível de radiação (fluxo radiante incidente: $\mathrm{Wm}^{-2} \mathrm{~nm}^{-1}$ ) em suas diferentes porções, atmosfera urbana, rural e outras características são os processos mais relevantes para o estudo de bacias aéreas. 
A figura 2.5 apresenta as inter-relações e interações de alguns poluentes na troposfera, como $\mathrm{CO}_{2}, \mathrm{COV}, \mathrm{NO}_{\mathrm{x}}, \mathrm{SO}_{\mathrm{x}}$ e outros.

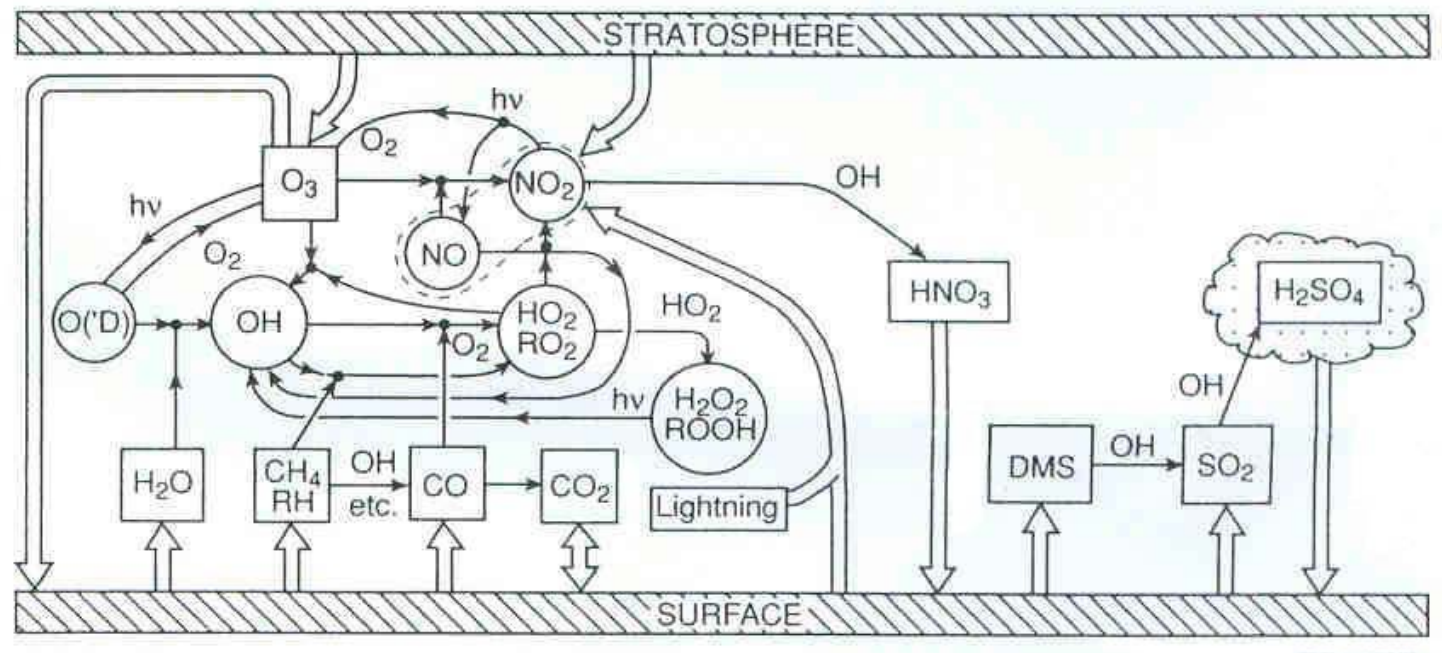

101306/.01296000

Figura 2.5- Diagrama esquemático dos principais processos químicos e fotoquímicos que afetam a composição global da troposfera

Fonte: BRASSEUR (1999)

Brasseur (1999) mostra de forma resumida que os compostos químicos são disposto na atmosfera por processos antropogênicos e naturais e removidos por deposição seca e úmida. Os compostos orgânicos ( $\mathrm{R}$ representa radicais orgânicos), metano, monóxido e dióxidos de carbono, óxidos de nitrogênio, ácido nítrico e peroxiacetil nitrato (PAN), compostos hidrogenados como peróxido de hidrogênio, hidroxila $(\mathrm{OH})$ e peroxila $\left(\mathrm{HO}_{2}\right)$, ozônio e compostos de enxofre como dióxido de enxofre, dimetilsulfeto (DMS) e ácido sulfúrico são alguns exemplos de componentes que interagem na troposfera, com a presença de umidade e de radiação ultravioleta.

O tempo de permanência de cada poluente varia na atmosfera, dependendo principalmente das condições meteorológicas de dispersão, diluição, temperatura, umidade e mesmo cinética química em presença ou ausência de determinadas espécies.

Na figura 2.6 a interação da radiação com os gases presentes na atmosfera é mostrada fora da atmosfera (topo-termosfera) e ao nível do mar, de acordo com o comprimento de onda incidente. 


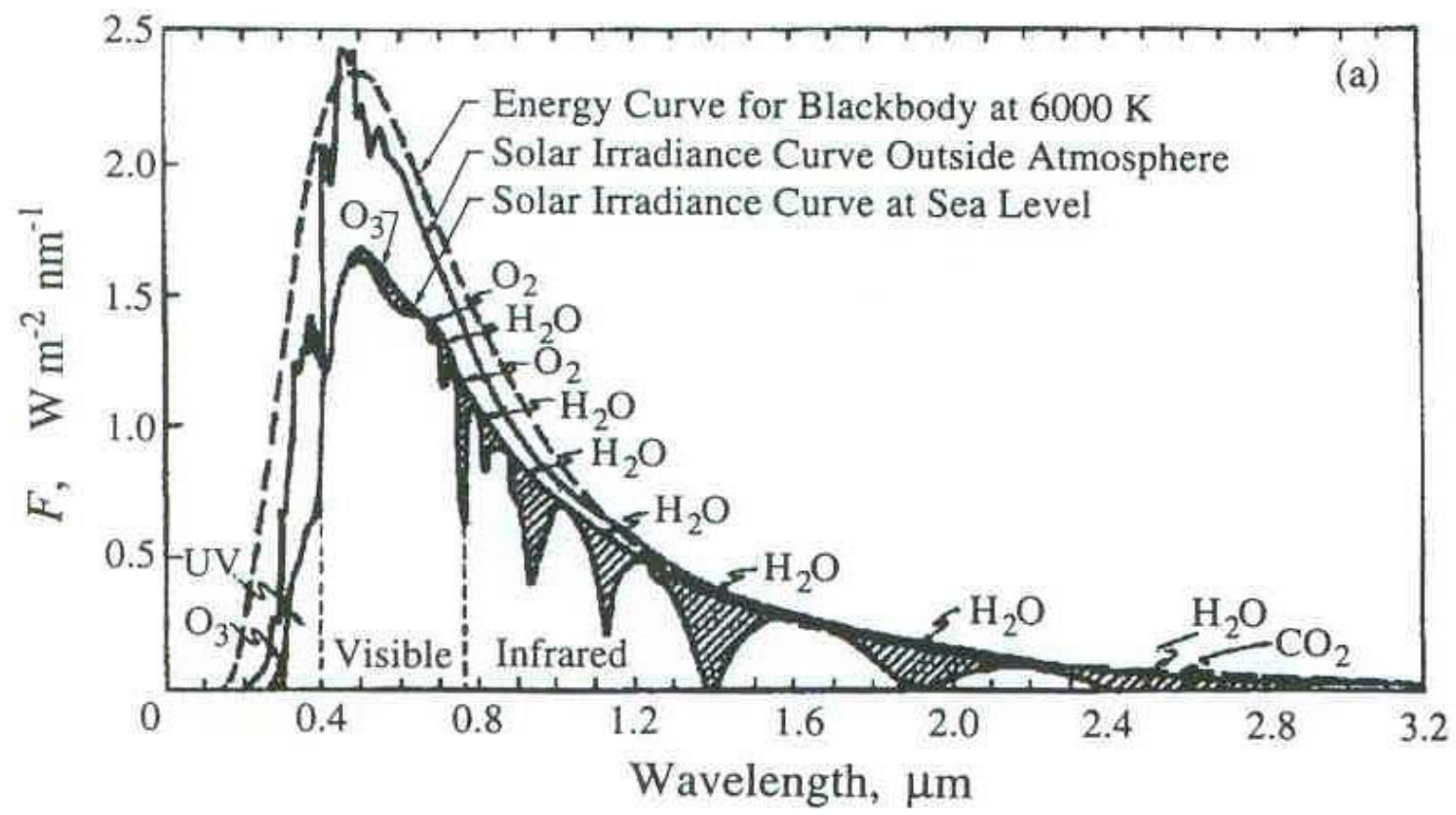

Figura 2.6- Espectro da radiação solar no topo da atmosfera e ao nível do mar. As áreas rachuradas indicam a absorção feita pelas moléculas Fonte SIENFELD (2006)

A formação do ozônio é um exemplo claro da complexidade de fatores que se somam para que ocorra sua formação, dada pela inter-relação entre as concentrações de hidrocarbonetos não-metânicos COV (composto orgânico volátil) que compreendem os compostos orgânicos com exceção do metano $\left(\mathrm{CH}_{4}\right)$ provenientes de plantas e antropogenicamente como indústrias (emissões pontuais, área, evaporativas e fugitivas), plantas de geração de energia, combustíveis e fontes móveis.

Mayer (1999) define $\mathrm{O}_{\mathrm{x}}$ como a soma do $\mathrm{NO}_{2}$ e $\mathrm{O}_{3}$ mais apropriado que só o valor do $\mathrm{O}_{3}$ uma vez que leva em conta processos de reversibilidade da reação fotoquímica. Hobbs (2000) coloca a importância de se identificar substâncias com comportamentos próximos em famílias químicas. Assim tem-se também:

- $\mathbf{O}_{\mathbf{Y}}=\left(\mathrm{O}, \mathrm{O}^{*}, \mathrm{O}_{3}\right)$

$-\mathbf{N O}_{\mathbf{X}}=\left(\mathrm{NO}, \mathrm{NO}_{2}, \mathrm{NO}_{3}\right)$

- $\mathbf{N O}_{\mathbf{Y}}=\left(\mathrm{N}_{\mathrm{x}} \mathrm{O}_{5}, \mathrm{HNO}_{3}, \mathrm{PAN}, \mathrm{NO}_{\mathbf{x}}\right)$

O ozônio têm sua concentração na atmosfera dada em função da estação do ano (ciclo anual) condição de clima local e cobertura de nuvens. O horário do dia (ciclo diário dos precursores) e também à relação de concentração entre $\mathrm{COV} / \mathrm{NO}_{\mathrm{x}}$ e indiretamente pela 
presença em maior ou menos grau de hidroxila no meio durante são decisivos para sua formação numa escala de tempo menor.

\subsubsection{1- Fotólise e formação do ozônio troposférico}

Após a oxidação dos COVs pelo radical hidroxila $\mathrm{OH}$ e presença de óxidos de nitrogênio $\mathrm{NO}_{\mathrm{x}},\left(\mathrm{NO}\right.$ e $\left.\mathrm{NO}_{2}\right)$ proveniente basicamente de processo de combustão com ar, interagindo de acordo com a intensidade da radiação $h v$ que chega à troposfera, em comprimento de onda próximo a 320nm acontece a fotólise e consequentemente a formação do ozônio troposférico.

Na figura 2.7 a seguir, Hobbs (2000) apresenta algumas das principais reações químicas envolvendo o radical $\mathrm{OH}$, poderoso oxidante produzido primariamente por reações fotoquímicas. Também são ilustrados os mecanismos de oxidação de $\mathrm{O}_{3}, \mathrm{HO}$ e $\mathrm{H}_{2} \mathrm{O}_{2}$ em reações fotoquímicas na atmosfera.

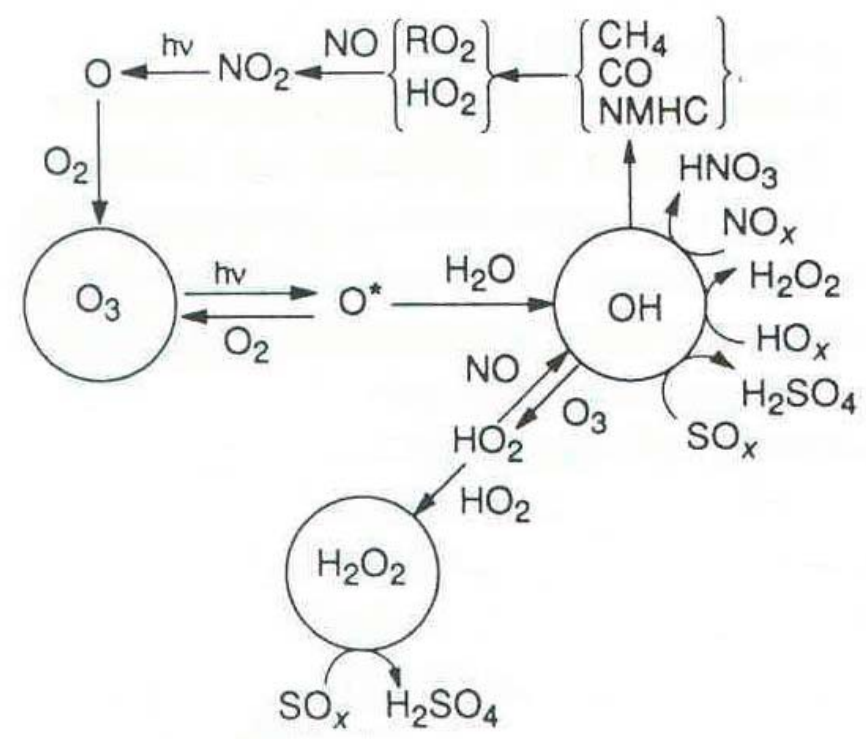

Figura 2.7- Diagrama sistemático ilustrativo das regras de reações fotoquímicas do $\mathrm{O}_{3}, \mathrm{OH}, \mathrm{HO}_{2}$ e $\mathrm{H}_{2} \mathrm{O}_{2}$ na atmosfera

Fonte HOBBS (2000)

Assim nota-se que nas reações que envolvem a fotólise (quebra de moléculas através da ação da radiação) os radicais livres $\left(\mathrm{O}^{*}\right.$ e $\mathrm{OH}$ por exemplo) desempenham papel chave na química da atmosfera, no ciclo de reações químicas e na manutenção das concentrações de estado estacionário de várias espécies químicas. 
A formação do ozônio na troposfera inicia-se com a fotólise de $\mathrm{NO}_{2}$ por comprimentos de onda inferiores a $380 \mathrm{~nm}$. Seguem-se as reações:

$$
\begin{aligned}
& \mathrm{NO}_{2}+\mathrm{hv} \rightarrow \mathrm{O}+\mathrm{NO} \\
& \mathrm{O}+\mathrm{O}_{2}+\mathrm{M} \rightarrow \mathrm{O}_{3}+\mathrm{M}
\end{aligned}
$$

(onde $\mathrm{M}$ é chamado terceiro corpo, inerte na reação mas necessário para a estabilidade energética e possibilidade de ocorrência da reação. Podem ser: $\mathrm{N}_{2}, \mathrm{O}_{2}, \mathrm{Ar}, \mathrm{H}_{2} \mathrm{O}$ ).

O balanço líquido da reação acima fica:

$$
\mathrm{NO}_{2}+\mathrm{O}_{2}+h v \rightarrow \mathrm{NO}+\mathrm{O}_{3}
$$

Cabe colocar que algumas substâncias (espécies) químicas funcionam como reservatórios de $\mathrm{O}_{3}$, na medida em que apresentam oxigênio de fácilmente disponível para oxidação, tais como: $\mathrm{HO}_{2}$ (hidroxiperoxil), $\mathrm{CH}_{3} \mathrm{O}_{2}, \mathrm{H}_{2} \mathrm{O}, \mathrm{H}_{2} \mathrm{O}_{2}, \mathrm{NO}_{2}$ e outros.

Assim a formação do ozônio não necessariamente ocorre próximo à fonte de emissão dos poluentes primários que o formam. As condições meteorológicas, a disponibilidade de hidroxilas e presença de reservatórios para liberação de oxigênio atômico, assim como a presença de $\mathrm{NO}_{\mathrm{x}}$ e COV são fatores que influenciam a formação do $\mathrm{O}_{3}$ troposférico.

A Figura 2.8 apresenta de forma esquemática as principais reações químicas que envolvem a formação e consumo de ozônio, através da interação de $\mathrm{O}_{3}, \mathrm{O}, \mathrm{O}$ (oxigênio exitado) e $\mathrm{NO}_{2}$ na presença do terceiro corpo $\mathrm{M}\left(\mathrm{N}_{2}, \mathrm{O}_{2}, \mathrm{Ar}, \mathrm{H}_{2} \mathrm{O}\right)$. O equilíbrio desta reação é chamado de estado foto-estacionário.

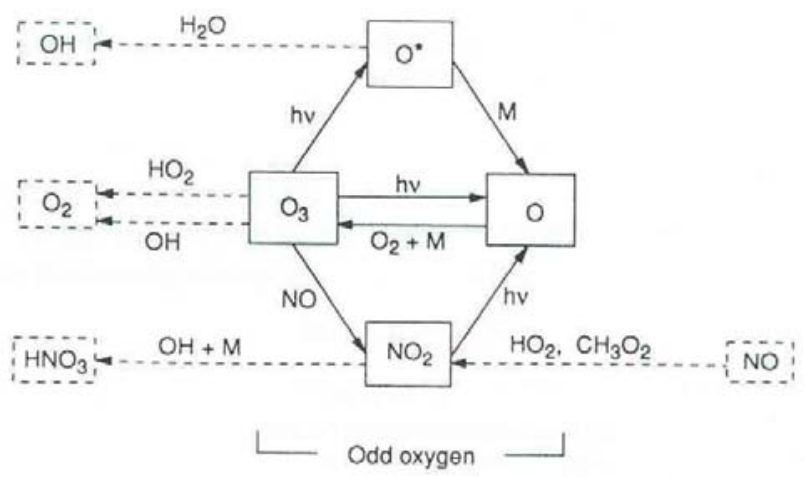

Figura 2.8- Equilíbrio foto-estacionário do ozônio troposférico Fonte HOBBS (2000) 
A alteração do equilíbrio foto-estacionário mostrado na figura 2.8 ocorre quando dada espécie se apresenta em maior quantidade na reação química - Lei de Le Chateilier e deslocamento do equilíbrio químico. Wakamatsu (2006) mostra que a relação ótima para a formação de ozônio está numa relação próxima de $\mathrm{COV} / \mathrm{NO}_{\mathrm{x}}=7$, levantada nas condições da área de Kanto, Japão.

A figura 2.9 ilustra esta inter-relação, medida em 1981 em Kanto- Japão e apresenta a concentração em ppb de ozônio quando de diferentes relações entre $\mathrm{NO}_{\mathrm{x}}$ e COV (NMHCNon Metanic Hidrocarbon Componds), mostrando a máxima concentração do poluente (números dentro das curvas levantadas).

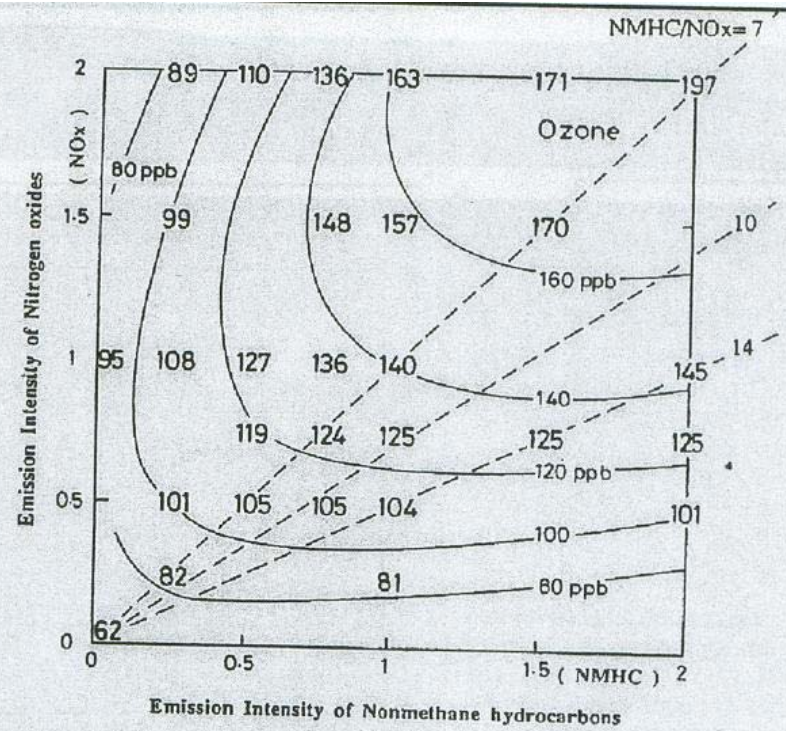

Figura 2.9- Relação entre a intensidade da emissão de $\mathrm{NO}_{\mathrm{x}}$, COV (NMHC) e concentração máxima de ozônio na região de Kanto-Japão 1981

Fonte: WAKAMATSU (2006)

O conhecimento do comportamento dos poluentes é necessário para que se estabeleçam ações efetivas de redução das emissões tenham maior eficácia. Durante a semana (densidade de tráfego) os valores de NO são maiores que os do final de semana, efeito percebido também no $\mathrm{NO}_{2}$. O NO é percebido em concentrações maiores pela manhã e à noite sendo que as quedas de concentrações registradas à tarde se devem ao fato da redução do $\mathrm{O}_{3}$.

Já as concentrações de ozônio são mais percebidas em estações de monitoramento com forte influência de tráfego e com valores mais elevados durante à tarde, devido a formação 
de ozônio nas reações fotoquímicas. Estações no campo e periferia (fora do centro) geralmente apresentam valores de concentração de ozônio mais baixos. Nos finais de semana as concentrações de $\mathrm{O}_{3}$ são um pouco maiores que dias de semana, fato que não se verifica para o $\mathrm{O}_{\mathrm{x}}$.

O comportamento temporal dos poluentes atmosféricos é parecido em muitas das grandes cidades do mundo sendo que, pequenas alterações neste comportamento são explicadas pela proximidade do mar e efeitos meteorológicos de curta duração, a variação das concentrações dos poluentes em cada cidade, as diferentes condições de emissão, a poluição de fundo, condições meteorológicas específicas e localidades das estações de monitoramento.

Os padrões de qualidade do ar são relacionados geralmente a poluentes isolados e, no caso do gerenciamento da qualidade do ar em cidades, a exposição da população se dá para a mistura de substâncias presentes na atmosfera.

A definição de índices que efetivamente representem condições ambientais e ambientais e médicas, que sejam claros, passíveis de utilização em planejamento urbano e em ações na saúde pública são importantes para orientação e conhecimento dos órgãos responsáveis, garantindo o bem-estar público e manutenção da qualidade do meio.

\subsection{3- Bacia Aérea (Meio Suporte e Conceito Bolha)}

- Em princípio, uma porção de ar pode absorver apenas uma porção fixa de poluição antes de exceder um ou mais padrões de qualidade do ar-PQAr

- Capacidade (meio) de suporte: a capacidade da atmosfera de uma região receber os remanescentes das fontes emissoras de forma a serem atendidos os padrões ambientais e os diversos usos dos recursos naturais. (Resolução Conama n³82 art $3^{\circ}$ inciso I)

- Conceito Bolha é o limite imaginário colocado como artifício acima das fontes de poluição do ar. Ao invés de regulamentar uma só fonte em uma planta industrial, passa a fixar um limite máximo de emissão para diversas fontes existentes numa planta, ou grupo de plantas, do mesmo empreendimento, como se estas estivessem sob uma grande bolha, com uma única abertura no topo. (LANDAU, 1985) 
O homem é o principal agente modificador da estrutura e funcionamento do ambiente no qual estão inseridas as comunidades e os recursos dos quais necessita. Desta forma há a necessidade de um bom gerenciamento ambiental e que requer a compreensão de padrões e processos dos sistemas ecológicos e desenvolvimento de procedimentos de avaliação que assegurem a proteção dos recursos naturais, de forma a garantir os níveis razoáveis de população, produção e consumo.

O meio suporte (bacia aérea) refere-se, em geral aos limites físicos dos usos dos recursos naturais, à disposição dos resíduos gerados e à energia disponível para determinada população ou comunidade em uma escala local, regional ou global.

\subsubsection{1- Sistemas ecológicos}

A Ecologia utiliza-se da Teoria Geral dos Sistemas e das Leis da Termodinâmica na definição e estudos dos sistemas ecológicos ou ecossistemas.

Assim, segundo ODUM (1988) ecossistema (unidade funcional básica na Ecologia) é constituído pelos organismos que vivem em uma determinada área (a comunidade biológica) e interagem entre si e com o ambiente físico, de tal forma que, um fluxo de energia produza estruturas bióticas definidas e uma ciclagem de materiais entre as partes vivas e não-vivas. Sendo, ainda, um sistema aberto, dependente de um fluxo contínuo de entrada de energia e matéria, um ecossistema, seja qual for sua escala de aplicação, apresenta um ambiente de entrada (de energia, materiais e organismos) e um ambiente de saída (de energia, materiais processados e organismos) acoplados e essenciais para que o sistema funcione e se mantenha, e que, portanto, devem ser considerados em qualquer abordagem ou análise sistêmica.

\subsubsection{2- Energia nos ecossistemas}

Obedecendo às leis da termodinâmica, o fluxo de energia no ecossistema se dá pelas transformações e transações de energia através das relações entre seus componentes (ou fatores ambientais). Como nenhuma transformação espontânea de energia é 100\% eficiente, uma parte se dispersa em energia térmica não-disponível (entropia). O termo entropia também é utilizado como um índice geral da desordem associada à degradação da energia. 
O ecossistema possui a característica de conseguir manter um alto grau de ordem interna (baixa entropia), através de uma contínua e eficiente dissipação de energia de alta utilidade (por exemplo, luz ou alimento) para dar energia de baixa utilidade (calor). É através da respiração total da comunidade, que "expulsa" continuamente a desordem, que a "ordem" de uma estrutura complexa de biomassa é mantida.

O ecossistema como um sistema termodinâmico aberto, troca continuamente energia e matéria com o ambiente externo adjacente para diminuir a entropia interna, à medida que aumenta a entropia externa. E, pode ser considerado ainda, um sistema fora do ponto de equilíbrio, uma vez que, verifica-se a tendência à auto-organização e auto-ajuste.

Em adição, ODUM (1988) apresenta a relação entre complexidade estrutural e entropia, e explica que à medida que aumentam o tamanho e a complexidade de um sistema, o custo energético de manutenção tende a aumentar proporcionalmente, a uma taxa maior. Ou seja, quanto maior e mais complexo um sistema, maior a quantidade de energia que deverá ser desviada para se reduzir o aumento da entropia (desordem) associado à manutenção da maior complexidade estrutural e funcional. Existem retornos crescentes com a escala, ou economias de escalas, associados a um aumento de tamanho e da complexidade, tais como melhor qualidade e estabilidade frente a perturbações, como também existem retornos minguantes com a escala (deseconomias de escala), envolvidos no maior custo necessário para se livrar da desordem. Estes retornos minguantes são inerentes a sistemas grandes e complexos, podendo ser diminuídos por melhorias no projeto básico que aumentem a eficiência de transformação da energia.

\subsubsection{3- Estabilidade de ecossistemas}

Segundo ODUM et al. (1988) a definição do termo "estabilidade" assume diferentes acepções em diferentes áreas do conhecimento, principalmente quando se tenta medí-la ou quantificá-la. Sob perspectiva ecológica, pode ser de dois "tipos", que podem estar inversamente relacionados e podem ser mutuamente exclusivos (i.e, difícil desenvolveremse ao mesmo tempo) (Figura 2.10):

- estabilidade de resistência: indica a capacidade de um ecossistema de resistir a perturbações e de manter intactos sua estrutura e seu funcionamento. 
- estabilidade de elasticidade (resiliência): indica a capacidade de se recuperar quando o sistema é deslocado do seu estado de equilíbrio (dinâmico) por uma perturbação.

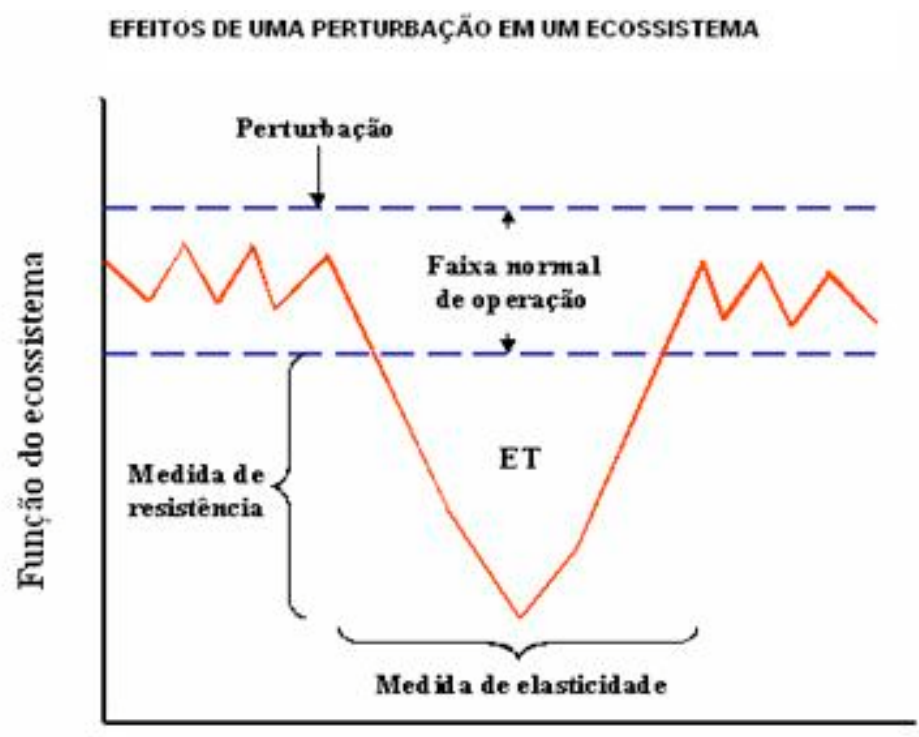

Tempo

Figura 2.10- Estabilidade de resistência e de elasticidade. Efeitos de uma perturbação em um ecossistema. A área denominada ET é uma medida relativa da estabilidade total

Fonte: ODUM et al. (1998)

A estabilidade de um ecossistema é um atributo da comunidade biológica, portanto, é função da resposta da comunidade frente a perturbações (STILING, 2002). Dito isso, os conceitos acima podem ser apresentados conforme em STILING (2002), sem correr o risco de uso e/ou interpretação indevida dos termos:

- Resistência: capacidade de uma população resistir a perturbações. Pode ser medida como a máxima magnitude de um tensor a qual não causa qualquer resposta. $\mathrm{Ou}$, ainda, a força necessária para provocar mudanças estruturais na comunidade.

- Resiliência: capacidade de uma comunidade retornar ao equilíbrio após uma perturbação (entende-se como equilíbrio, quando mudanças significativas no tamanho das populações ou no número de espécies não ocorrem em um dado período - anos ou poucas décadas). Inclui:

- elasticidade: o quão rapidamente uma comunidade retorna ao equilíbrio;

- amplitude: o quanto de perturbação pode sofrer uma comunidade sem que sua capacidade de resposta seja ultrapassada, sendo possível sua recuperação. 
Em resumo, todos os sistemas ecológicos são governados por um conjunto de princípios gerais, entre os mais importantes estão que estes funcionam dentro de limites das leis da termodinâmica governando transformações de energia, que o meio ambiente físico exerce uma influência controladora na produtividade dos ecossistemas e que a estrutura e a dinâmica das comunidades ecológicas são reguladas pelos processos populacionais (RICKLEFS, 1996).

Nem é preciso mencionar que o aumento da população humana e a velocidade com que o homem vem explorando os recursos naturais em função de sua dependência de energia e matéria do ambiente natural, vêm gerando crescente preocupação e, a atenção se volta para o paradigma da sustentabilidade.

Usando a mesma linha de raciocínio o tamanho ideal da atividade produtiva de um ecossistema (bacia aérea) que pode ser mantida em uma escala de tempo que englobe as futuras gerações e a possibilidade de sustentação de vida no planeta, sem que sejam ultrapassados os limites da capacidade regenerativa e de assimilação, e, portanto, sem prejuízos permanentes à estrutura e ao funcionamento do sistema ecológico. Tais conceitos são utilizados pelos Decretos Estaduais n48.523/04, n50.753/06 e n52.469/07, uma vez que definem a área de abrangência, o tipo de poluente e o gerenciamento das bacias, os limites temporais, territoriais e materiais, além da previsão da compensação entre fontes fixas e móveis.

A aplicação destes conceitos ao licenciamento ambiental é algo já existente nos EUA e também no Brasil, no Estado de São Paulo inclusive. Segundo SANTOS e SALVADOR (2004), o Conceito Bolha (conhecido como "Bubble Concept") já vinha sendo aplicado nos Estados Unidos da América pela EPA - Environmental Protection Agency - desde 1979 em alguns Estados Americanos, sendo que em 25 de junho de 1984 a Suprema Corte dos Estados Unidos da América do Norte confirmou a autoridade da EPA e das Agências de Controle de Poluição dos Estados para facilitar o uso do "Bubble Concept" em âmbito nacional, no cumprimento da Lei do Ar Limpo, dando mais rapidez na implantação de processos industriais e ampliações das unidades existentes. 
No Brasil, o Estado de São Paulo foi pioneiro na aplicação do Conceito Bolha, cujo início data de 1985 no Município de Cubatão, em plena vigência do Programa de Controle de Poluição desenvolvido pela CETESB. A expectativa era que as reduções significativas das cargas poluidoras nas fontes emissoras diminuiriam, na mesma proporção, as concentrações dos poluentes na atmosfera, permitindo o enquadramento da qualidade do ar da Região aos padrões legais vigentes. Essa hipótese ganhou corpo entre as entidades da sociedade civil, levando os empresários a pleitear a introdução de novos empreendimentos industriais ou ampliações dos existentes. O momento político da época se caracterizava pela participação intensa da população nas decisões governamentais, o que aumentou a pressão no sentido do desenvolvimento industrial, pois na área se encontravam indústrias de base que sempre atraem empresas satélites. (SANTOS e SALVADOR, 2004). 


\section{3- JUSTIFICATIVAS PARA AS ALTERAÇÕES NO LICENCIAMENTO}

O Decreto Estadual $n^{\circ} 8.468$, de 8 de setembro de 1976, que aprovou o regulamento da Lei n 997 , de 31 de maio de 1976, que dispõe sobre a prevenção e o controle da poluição do meio ambiente sofreu alteração em 2 de março de 2004 em vários de seus artigos pelo Decreto Estadual n 48.523 , Decreto Estadual n 50.753 em 28 de abril de 2006 e Decreto Estadual n52.469 em 12 de dezembro de 2007.

Para fins de comparação entre as normas chamou-se aqui de redação anterior ao texto referente ao Decreto Estadual n8.468/76 e suas alterações anteriores à publicação dos Decretos Estaduais n48.523/04 e 50.753/06 (nova redação) e de novíssima redação o texto aprovado em 2007 (Decreto Estadual n52.469/07).

A forma de redação do Decreto Estadual nº8.468/76 impunha restrições ao desenvolvimento econômico de várias atividades, principalmente as indústrias de geração de energia e pólos industriais quando da aplicação da lei, que não era suficientemente clara.

A revisão do Decreto $n^{\circ} 8.468 / 76$ (base da prevenção e controle da poluição no Estado de São Paulo) também se justificou tendo-se como base a evolução do conhecimento técnico por parte das instituições do Estado, e mesmo fora dele, a evolução da tecnologia e as alterações da percepção social sobre os problemas de poluição que vinham exigindo a revisão de alguns dos tópicos do citado decreto, confirmada inclusive por alterações recentes realizadas pelos Decretos Estaduais n 47.397 e 47.400, ambos de dezembro de 2002, que introduziram o conceito de melhoria contínua através da necessidade da renovação da Licença de Operação, trazendo automaticamente a indústria para ser partícipe da solução.

Decreto Estadual $n^{\circ} 8.468 / 76$ caracterizava como sendo área saturada toda região em que foi constatada uma concentração de poluentes acima do padrão de qualidade, que acaba por impedir que se instalem novos empreendimentos potencialmente poluidores nessa região.

Os Decretos n48.523/04, n50.753/06 e n52.469/07 alteram critérios de determinação de área saturada e seu gerenciamento, alterando a forma de licenciamento de fontes de poluição tendo como referência o conceito de gestão de bacias aéreas (licenciamento em 
área saturada) e o de desenvolvimento sustentável com comércio de emissões no âmbito do Estado de São Paulo.

Assim as principais alterações são apresentadas em três aspectos principais, de forma a facilitar a comparação das normas: (3.1) Área de abrangência; (3.2) Tipo de poluente e; (3.3) Gerenciamento das áreas saturadas.

\section{1- Abrangência da área}

Cite-se o exemplo de Cubatão que, por ter concentrações excessivas de alguns poluentes, acabaria por impedir, em tese, a instalação de novas fontes potencialmente poluidoras em outros municípios da Baixada. Sob a luz do melhor conhecimento técnico pode-se afirmar que este rigor não é razoável, pois traz conseqüências econômicas claras e sem qualquer benefício ao meio ambiente, uma vez que a poluição gerada em Cubatão não atingirá, ou atingirá de forma incipiente, a região de Peruíbe, por exemplo. A nova proposição restringe a área saturada aos contornos do município ou a algo muito próximo a isso, permitindo o desenvolvimento em áreas próximas.

Pela revisão de 2007 incluiu-se a possibilidade de alteração do limite territorial da bacia de acordo com a evolução do conhecimento climatológico e das fontes de emissão de uma dada região.

\section{Redação anterior (8.468/76 e alterações):}

Art. 20 - Para efeito de utilização e preservação do ar, o território do Estado de São Paulo fica dividido em 11 (onze) Regiões, denominadas Regiões de Controle de Qualidade do Ar - RCQA.

$\S 1^{\circ}$ - As regiões a que se refere este artigo deverão coincidir com as 11 (onze) Regiões Administrativas do Estado, estabelecidas no Decreto estadual $n^{0} 52.576$, de 12 de dezembro de 1970, a saber:

1 - Região da Grande São Paulo - RCQA 1;

2 - Região do Litoral - RCQA 2;

3 - Região do Vale do Paraíba - RCQA 3;

4 - Região de Sorocaba - RCQA 4;

5 - Região de Campinas - RCQA 5;

6 - Região de Ribeirão Preto - RCQA 6;

7 - Região de Bauru - RCQA 7;

8 - Região de São José do Rio Preto - RCQA 8;

9 - Região de Araçatuba - RCQA 9;

10 - Região de Presidente Prudente - RCQA 10;

11 - Região de Marília - RCQA 11. 
$\S 2^{\circ}$ - Para a execução de programas de controle da poluição do ar, qualquer Região de Controle de Qualidade do $\mathrm{Ar}$ poderá ser dividida em sub-regiões, constituídas de um, de dois ou mais Municípios, ou, ainda, de parte de um ou de partes de vários Municípios.

\section{Nova redação (48.523/04 e 50.753/06):}

Artigo $2^{\circ}$ - Ficam acrescentados os parágrafos $3^{\circ}, 4^{\circ}, 5^{\circ}$ e $6^{\circ}$ ao artigo 20 do Regulamento da Lei $n^{\circ} 997$, de 31 de maio de 1976, aprovado pelo Decreto $n^{\circ} 8.468$, de 8 de setembro de 1976 e posteriores alterações, com a seguinte redação:

$\S 3^{\circ} \mathrm{A}$ sub-região de gerenciamento da qualidade do ar para os poluentes primários é o território do município, exceto no caso de conurbação em que a sub-região compreenderá todos os municípios conurbados.

$\S 4^{\circ}$ Considera-se como sub-região de gerenciamento da qualidade do ar para os poluentes secundários, toda a área que diste até $30 \mathrm{Km}$ de qualquer estação que gere dados validados pela CETESB, podendo esta alterar o contorno da área mediante decisão motivada.

$\S 5^{\circ}$ No caso de estação não operada pela CETESB, sua validação implicará a verificação da adequabilidade do local em que ela estiver instalada, dos procedimentos operacionais e da manutenção dos equipamentos utilizados.

$\S 6^{\circ}$ Para os efeitos deste Regulamento, consideram-se:

1. poluentes primários aqueles diretamente emitidos pelas fontes de poluição, tais como, partículas em suspensão, monóxido de carbono, dióxido de enxofre e dióxido de nitrogênio;

2. poluentes secundários, aqueles formados a partir de reações entre outros poluentes".

\section{Novíssima redação (52.469/07):}

I - O artigo 20:

"Artigo 20 - Para efeito de utilização e preservação do ar, o território do Estado de São Paulo fica dividido em Regiões, denominadas Regiões de Controle de Qualidade do Ar - RCQA.

$\S 1^{\circ}$ - As regiões a que se refere este artigo deverão coincidir com as Regiões Administrativas do Estado, estabelecidas no Decreto $n^{\circ} 52.576$, de 12 de dezembro de 1970, com suas alterações posteriores.

$\S 2^{\circ}$ - Para a execução de programas de controle da poluição do ar, qualquer Região de Controle de Qualidade do $\mathrm{Ar}$ poderá ser dividida em sub-regiões, constituídas de um, de dois ou mais Municípios, ou, ainda, de parte de um ou de partes de vários Municípios.

$\S 3^{\circ}$ - A abrangência da sub-região de gerenciamento da qualidade do ar onde houver estação de medição da qualidade do ar será:

1. para o ozônio, o território compreendido pelos municípios que, no todo ou em parte, estejam situados a uma distância de até $30 \mathrm{~km}$ da estação de monitoramento da qualidade do ar;

2. para os demais poluentes, o território do município onde está localizada a estação de monitoramento da qualidade do ar;

3. nos casos de conurbação, a CETESB poderá, mediante decisão tecnicamente justificada, ampliar a área compreendida pela sub-região, de modo a incluir municípios vizinhos.

$\S 4^{\circ}$ - No caso de estação de medição da qualidade do ar não operada pela CETESB, a validação dos dados implicará na verificação da adequabilidade do local em que ela estiver instalada, dos procedimentos operacionais e da manutenção dos equipamentos utilizados, conforme diretrizes e procedimentos estabelecido pela CETESB."; (NR)

Essas alterações procuram introduzir, nas análises de processos de licenciamento ambiental no Estado o conceito de qualidade do meio, de acordo com as características regionais (vocação de cada porção do Estado). Vale ressaltar que trata-se de uma mudança cultural no órgão ambiental e demanda de esforço dos vários setores, no sentido de vencer as resistências internas e externas, além da mudança de mentalidade na prática do licenciamento. 


\section{2- Ao tipo de poluente}

Pelo decreto anterior, o desrespeito a um dos padrões ambientais implicaria na restrição de instalação de qualquer tipo de fonte na área saturada. Assim, uma região que possuía desconformidades em relação ao poluente material particulado impedia a instalação de uma indústria que emite basicamente dióxido de enxofre. Novamente, não havia sustentação técnica e científica para que esse rigor seja adotado. A proposta ora apresentada caracteriza uma área saturada em relação apenas ao poluente que não atende aos padrões de qualidade, permitindo a instalação de fontes que emitam outros poluentes que o meio tem capacidade de suportar.

\section{Redação anterior (8.468/76 e alterações):}

Artigo 23 - Considera-se saturada, em termos de poluição do ar, uma Região ou Sub-Região, quando qualquer valor máximo dos padrões de qualidade do ar nelas estiver ultrapassado.

\section{Nova redação (48.523/04 e 50.753/06):}

Artigo 23 - Determina-se o grau de saturação da qualidade do ar de uma sub-região quanto a um poluente específico, cotejando-se as concentrações verificadas nos últimos 3 (três) anos com os Padrões de Qualidade do Ar (PQAR) estabelecidos no artigo 29 deste Regulamento e na Resolução CONAMA n $3 / 90$ ou regulamentação correlata superveniente.

$\S 1^{0}$ - As sub-regiões a que se refere este artigo, serão classificadas de acordo com os seguintes critérios:

1. para exposição de longo prazo:

a) sub-regiões com 3 (três) anos representativos:

1. saturada (SAT): média aritmética das médias anuais dos últimos 3 (três) anos maior que o PQAR;

2. em Vias de Saturação (EVS): média aritmética das médias anuais dos últimos 3 (três) anos maior que $90 \%$ (noventa por cento) do PQAR;

3. não Saturada (NS): média aritmética das médias anuais dos últimos 3 (três) anos menor ou igual a 90\% do PQAR;

b) sub-regiões com 2 (dois) anos representativos:

1. SAT: média aritmética das médias anuais dos 2 (dois) anos maior que 90\% (noventa por cento) do PQAR;

2. EVS: média aritmética das médias anuais dos 2 (dois) anos maior que $80 \%$ (oitenta por cento) do PQAR;

3. NS: média aritmética das médias anuais dos 2 (dois) anos menor ou igual a 80\% (oitenta por cento) do PQAR;

c) sub-regiões com 1 (um) ano representativo:

1. SAT: média anual maior que $90 \%$ (noventa por cento) do PQAR;

2. EVS: média anual maior que $80 \%$ (oitenta por cento) do PQAR;

3. NS: média anual menor ou igual a $80 \%$ (oitenta por cento) do PQAR;

2. para exposição de curto prazo:

a) sub-regiões com 3 (três) anos representativos:

1. SAT: $4^{\circ}$ maior valor diário dos últimos 3 (três) anos maior que o PQAR;

2. EVS: $3^{\circ}$ maior valor diário dos últimos 3 (três) anos maior que $90 \%$ (noventa por cento) do PQAR;

3. NS: $3^{\circ}$ maior valor diário dos últimos 3 (três) anos menor ou igual a 90\% (noventa por cento) do PQAR;

b) sub-regiões com 2 (dois) anos representativos:

1. SAT: $3^{\circ}$ maior valor diário dos últimos 3 (três) anos maior que o PQAR;

2. EVS: $2^{\circ}$ maior valor diário dos últimos 3 (três) anos maior que $90 \%$ (noventa por cento) do PQAR;

3. NS: $2^{\circ}$ maior valor diário dos últimos 3 (três) anos menor ou igual a 90\% (noventa por cento) do PQAR;

c) sub-regiões com 1 (um) ano representativo: 
1. SAT: $2^{\circ}$ maior valor diário dos últimos 3 (três) anos maior que o PQAR;

2. EVS: $1^{\circ}$ maior valor diário dos últimos 3 (três) anos maior que $90 \%$ (noventa por cento) do PQAR;

3. NS: $1^{\circ}$ maior valor diário dos últimos 3 (três) anos menor ou igual a 90\% (noventa por cento) do PQAR;

d) sub-regiões com nenhum ano representativo:

1. SAT: $2^{\circ}$ maior valor diário dos últimos 3 (três) anos maior que o PQAR;

2. EVS: $1^{\circ}$ maior valor diário dos últimos 3 (três) anos maior que $90 \%$ (noventa por cento) do PQAR;

3. onde não se aplicarem as disposições anteriores por ausência de dados de monitoramento, a CETESB poderá classificar as sub-regiões quanto ao grau de saturação com base nos dados disponíveis sobre as fontes já instaladas, nas características da região e, se necessário, no uso de modelos de dispersão.

$\S 2^{\circ}$ - Para efeito de aplicação deste artigo, considera-se o seguinte:

1. ano representativo: aquele cujo número de valores diários válidos de amostragem da qualidade do ar em cada quadrimestre seja maior que 50\% (cinqüenta por cento) do total amostrado, respeitadas as metodologias de freqüência de amostragem;

2. média anual válida de amostragem da qualidade do ar: somente aquela obtida em ano representativo;

3. valor diário válido de amostragem da qualidade do ar: valor obtido em dia em que 2/3 (dois terços) dos dados horários são válidos;

4. dado horário válido: aquele que foi submetido a análise técnica e validado, pela CETESB;

5. médias anuais de valores de amostragem da qualidade do ar: médias calculadas nos termos do artigo 29 deste Regulamento e na Resolução CONAMA n 3/90, ou regulamentação correlata superveniente;

6. valor diário de cada poluente: concentração máxima verificada no dia, observados os tempos de exposição dos padrões de curto prazo estabelecidos no artigo 29 deste Regulamento e na Resolução CONAMA ${ }^{\circ} 3 / 90$, ou regulamentação correlata superveniente." (NR)

\section{Novíssima redação (52.469/07):}

"Artigo 23 - Determina-se o grau de saturação da qualidade do ar de uma sub-região quanto a um poluente específico, cotejando-se as concentrações verificadas nos últimos 3 (três) anos com os Padrões de Qualidade do Ar (PQAR) estabelecidos no artigo 29 deste Regulamento e na Resolução CONAMA n $3 / 90$ ou regulamentação correlata superveniente.

$\S 1^{\circ}$ - As sub-regiões a que se refere este artigo serão classificadas de acordo com os seguintes critérios:

$(\ldots)^{3}$

$\S 4^{\circ}$ - As sub-regiões a que se refere este artigo serão classificadas anualmente, mediante Resolução do Secretário do Meio Ambiente, por proposta da CETESB aprovada pelo CONSEMA."; (NR)

Nas alterações realizadas em 2007 incluiram-se o conceito de grau de severidade para concentração de poluentes na bacia e a maior participação da sociedade através da discussão das regiões saturadas e em vias de saturação que passam a ser discutidas no âmbito do CONSEMA - Conselho Estadual de Meio Ambiente do Estado de São Paulo, garantindo maior legitimidade na aplicação dos Decretos, uma vez de um conselho paritário, composto de trinta e seis (36) membros, sendo metade de seus representantes oriunda de órgãos do Estado e metade, da sociedade civil.

\footnotetext{
${ }^{3}$ A redação completa do artigo 23 do Decreto Estadual nº52.469/07 encontra-se no anexo 3 da página 123 deste trabalho.
} 
Offe (1984) afirma que o Estado não é instrumento e nem está à serviço das classes dominantes e de interesses específicos, mas sim interesses comuns de todos os membros de uma sociedade capitalista de classes. O tema não é atual, o que não justifica o temor de que apenas grandes corporações integrarem o planejamento de ações do Estado e, neste caso, não é evidente a teoria das influências.

Assim, espera-se maior transparência e publicidade no processo de licenciamento de forma a compatibilizar a qualidade do meio com o desenvolvimento econômico no Estado, embora as análises no CONSEMA não garantam o rigor no seu cumprimento.

\section{3- Gerenciamento das áreas saturadas}

A redação anterior do decreto não permitia a instalação de novos empreendimentos em áreas consideradas saturadas, bloqueando qualquer nova instalação potencialmente poluidora. Novas formas de gerenciamento tem sido aplicadas em vários países, notadamente nos Estados Unidos, se permitindo a instalação de novas fontes de poluição e, ao mesmo tempo, alcançando uma redução da poluição do ar, através de mecanismos chamados de "compensação". Na proposta ora apresentada, criam-se mecanismos gerenciais de forma que uma empresa possa se instalar numa região saturada desde que subtraia -ou compense de outras fontes- cerca de $10 \%$ a mais do que as novas emissões que serão liberadas pelo novo empreendimento. Aliás, tal mecanismo já é adotado para a Região Metropolitana de São Paulo com base na lei no 11.243 de 10 de outubro de 2002, artigo 15 parágrafo $3^{\circ}$. Esse zoneamento ambiental também é previsto no artigo $9^{\circ}$ da Lei Federal n6.938 de 31 de agosto de 1981 que institui a Política Nacional do Meio Ambiente, seus fins e mecanismos de formulação e aplicação estabelecidos os critérios para o Zoneamento Ecológico-Econômico no Brasil - ZEE pela Decreto Federal n4.297, em 10 de julho de 2002.

Os Decretos n48.523/04 e n50.753/06 apenas ampliam para todo o Estado de São Paulo esse moderno mecanismo de gerenciamento da qualidade do ar, expressa na revisão colocada pelo Decreto Estadual n52.469/07. Este último alterou também as redações dos Decretos anteriores, diminuindo a discricionariedade quanto ao mercado de redução de emissões atmosféricas para os poluentes regulamentados (geração, divulgação, cessão e extinção de créditos para fontes fixas e móveis) e flexibilização nos limites temporais (fases 
de aplicação do decreto), tornando legal o procedimento previsto para operacionalização do Decreto $n^{\circ} 50.753 / 06$, aumentando a legalidade e publicidade da legislação proposta.

Parte destas alterações justificaram-se pela falta de um inventário consolidado para fontes de poluição do ar e também pela pressão dos órgãos de planejamento e desenvolvimento do Estado no sentido de substituir o mecanismo de compensação proposto por um fundo com reversão do montante obtido em melhorias na própria bacia aérea, a exemplo do que é feito pelos Comitês de Bacias em Recursos Hídricos.

\section{Redacão anterior (8.468/76 e alteracões):}

Artigo 24 - Nas Regiões ou Sub-Regiões consideradas saturadas, a CETESB poderia estabelecer exigências especiais para atividades que lancem poluente.

Artigo 42 - Fontes novas de poluição do ar, que pretendam instalar-se ou funcionar, quanto a localização, serão:

I - obrigadas a comprovar que as emissões provenientes da instalação ou funcionamento não acarretarão, para a Região ou Sub-Região tida como saturada, aumento nos níveis dos poluentes que as caracterizem como tal;

II - proibidas de instalar-se ou de funcionar quando, a critério da CETESB, houver o risco potencial a que alude o inciso $\mathrm{V}$ do artigo $3^{\circ}$ deste Regulamento, ainda que as emissões provenientes de seu processamento estejam enquadradas nos incisos I, II, III e IV do mesmo artigo.

$\S 1^{\circ}$ - Para configuração do risco mencionado no inciso II, levar-se-á em conta a natureza da fonte, bem como das construções, edificações ou propriedades, passíveis de sofrer os efeitos previstos no inciso $\vee$ do artigo 39.

$\S 2^{\circ}$ - Ficará a cargo do proprietário da nova fonte comprovar, sempre que a CETESB o exigir, o cumprimento do requisito previsto no inciso $\mathrm{I}$.

\section{Nova redacão (48.523/04 e 50.753/06):}

Artigo 24 - Nas sub-regiões em vias de saturação e nas já saturadas, a Companhia de Tecnologia de Saneamento Ambiental - CETESB estabelecerá um Programa de Redução de Emissões Atmosféricas - PREA para os empreendimentos que se encontrem em operação.

$\S 1^{\circ}$ - Serão integrantes do PREA os empreendimentos que se enquadrem nos critérios estabelecidos no Anexo 11 deste Regulamento.

$\S 2^{\circ}$ - A renovação da Licença de Operação dos empreendimentos integrantes do PREA condiciona-se às seguintes exigências técnicas especiais:

1. a utilização de sistemas de controle de poluição do ar baseados na melhor tecnologia prática disponível;

2. a implementação de Plano de Monitoramento das Emissões Atmosféricas, segundo Termos de Referência estabelecidos pela CETESB;

3. o cumprimento de metas de redução de emissões, em termos de prazo e quantidade, estabelecidas pela CETESB para empreendimentos localizados em sub-regiões SAT:

a) as metas de redução de emissão serão estabelecidas tomando por base a contribuição relativa do empreendimento no inventário das fontes de poluição da respectiva sub-região;

b) a cada renovação da Licença de Operação a meta de redução poderá ser revista tendo por base o atingimento da meta anterior;

c) para o cumprimento das metas de reduções de emissões poderá ser utilizado o mecanismo de compensação de emissões por poluente, estabelecido no artigo 42-A, acrescentado por este decreto.". (NR)

IV - a alínea b do inciso I do artigo 29:

"b) 240 (duzentos e quarenta) microgramas por metro cúbico de partículas em suspensão, ou valor inferior concentração média de 24 horas consecutivas, não podendo ser ultrapassada mais de uma vez por ano." (NR) 
Artigo 42 - Fontes novas de poluição ou no caso da ampliação das já existentes que pretendam instalar-se ou operar, quanto à localização, serão:

$\mathrm{I}$ - proibidas de instalar-se ou de operar quando, a critério da CETESB, houver o risco potencial a que alude o inciso $\mathrm{V}$ do artigo $3^{\circ}$ deste Regulamento, ainda que as emissões provenientes de seu processamento estejam enquadradas nos incisos I, II, III e IV do mesmo artigo;

II - quando localizarem-se em regiões SAT e EVS e aludidas no anexo 11, obrigadas a compensar, conforme estabelecido no artigo 42-A acrescentado por este decreto, em 110\% (cento e dez por cento) e 100\% (cem por cento) das emissões atmosféricas a serem adicionadas dos poluentes que causaram os estados, respectivamente, de SAT ou EVS.

Parágrafo único - Para os fins de que trata o inciso II deste artigo, para empreendimentos localizados em municípios pertencentes a mais de uma sub-região, a compensação de emissões poderá ser efetuada entre os empreendimentos situados em qualquer dessas sub-regiões, considerando as exigências previstas para a sub-região." (NR)

\section{Novíssima redação (52.469/07):}

"Artigo 24 - Nas sub-regiões em vias de saturação e nas já saturadas, a Companhia de Tecnologia de Saneamento Ambiental - CETESB estabelecerá um Programa de Redução de Emissões Atmosféricas - PREA para os empreendimentos que se encontrem em operação.

$\S 1^{\circ}$ - Serão integrantes do PREA, além das fontes móveis, o conjunto de empreendimentos que integrem a classe A da curva $A B C$, que será definida por subregião e calculada com base no inventário do(s) poluente(s) que gerou(ram) a saturação.

$(\ldots)^{4}$

Artigo $5^{\circ}$ - Este decreto entra em vigor na data de sua publicação, ficando revogadas as disposições em contrário, em especial os incisos II, III e V do artigo $1^{\circ}$ e o artigo $2^{\circ}$ do Decreto $\mathrm{n}^{\circ} 50.753$, de 28 de abril de 2006.

Ainda como alteração do Decreto Estadual nº.468/76:

\section{Redação anterior (8.468/76 e alterações):}

Artigo $6^{\circ}$ - No exercício da competência prevista no artigo anterior, incluem-se entre as atribuições da CETESB, para controle e preservação do Meio-Ambiente:

II - efetuar levantamentos, organizar e manter o cadastramento de fontes de poluição;

\section{Nova redação (48.523/04 e 50.753/06):}

Artigo $6^{\circ}$, inciso II - Efetuar levantamento organizado e manter o cadastro das fontes de poluição e inventariar as fontes prioritárias - fixas e móveis - de poluição, segundo metodologias reconhecidas internacionalmente, a serem adotadas a critério da CETESB."(NR)

\section{Novíssima redação (52.469/07):}

VI - O artigo 42-B, acrescentado ao Regulamento da Lei no 997, de 31 de maio de 1976, pelo Decreto n 50.753, de 28 de abril de 2006:

"Artigo 42-B - A Companhia de Tecnologia de Saneamento Ambiental - CETESB publicará anualmente as seguintes informações:

I - a partir da classificação do grau de saturação das sub-regiões, metas de redução das emissões;

II - o inventário das emissões atmosféricas de fontes fixas e móveis, por sub-região e para o Estado de São Paulo, identificando os principais empreendimentos emissores, por poluente;

III - valor e titularidade dos créditos disponíveis nas sub-regiões, com os respectivos prazos de validade."; (NR)

\footnotetext{
${ }^{4}$ A redação completa do artigo 24 do Decreto Estadual n52.469/07 encontra-se no anexo 3 da página 123 deste trabalho.
} 
O Decreto Estadual n50.753/06 estipula valores para análises de pareceres, publicidade das informações e formas e valoração de infrações e que não serão foco de análise neste trabalho (Artigo 42-B). Entretanto a inclusão do Artigo 42-A pelo Decreto Estadual n48.523/04 e revisado no Decreto Estadual n50.753/06 estabelece ainda os critérios para geração de créditos obtidos através do licenciamento de novas fontes e ampliação de existentes (fixas) e também em fontes móveis, compensação entre fontes e extinção dos créditos que subsidia a discussão sobre o gerenciamento das áreas saturadas.

As alterações promovidas pelo Decreto $\mathrm{n}^{\circ 52.469 / 07}$ diminuindo a discricionariedade estipulando e legalizando a forma de aplicação das regulamentações anteriores no texto da lei.

Adicionalmente vale mencionar o anexo 11 do Decreto Estadual n50.753/06 (anexo 2 desta dissertação), referido no artigo $7^{\circ}$ que estipula as linhas de corte para obrigatoriedade de compensação de emissões adicionadas e assim integrantes do PREA (Programa de Redução de Emissões Atmosféricas).

\section{Nova redacão (48.523/04 e 50.753/06):}

ANEXO 11- 1. Serão integrantes do Programa de Redução de Emissões Atmosféricas (PREA) e obrigados a compensar as emissões adicionadas:

1.1. os empreendimentos cujo total de emissões é igual ou superior a:

a) Material Particulado (MP): 100 t/ano

b) Óxidos de Nitrogênio $\left(\mathrm{NO}_{\mathrm{x}}\right)$ : 40 t/ano

c) Compostos Orgânicos Voláteis, exceto metano (COVs, não- $\mathrm{CH}_{4}$ ): 40 t/ano

d) Óxidos de Enxofre ( $\left.\mathrm{SO}_{\mathrm{x}}\right): 250$ t/ano

e) Monóxido de Carbono (CO): 100 t/ano

1.2. os seguintes empreendimentos e atividades:

a) empresas automobilísticas e/ou aeronáuticas.

b) terminais e/ou bases de armazenamento, carga e descarga de combustíveis ou substâncias voláteis.

2. Definições

a) emissões: liberação de substâncias para a atmosfera a partir de fontes pontuais ou difusas;

b) óxidos de Enxofre: óxidos de enxofre, expressos em dióxido de enxofre $\left(\mathrm{SO}_{2}\right)$;

c) óxidos de Nitrogênio: óxido de nitrogênio e dióxido de nitrogênio, expresso em dióxido de nitrogênio $\left(\mathrm{NO}_{2}\right)$;

d) Composto Orgânico Volátil (COV) Não- Metano: todo composto orgânico, exceto o metano $\left(\mathrm{CH}_{4}\right)$, medido por um método de referência ou determinado por procedimentos estabelecidos pela CETESB.

\section{Novíssima redação (52.469/07):}

Artigo $2^{\circ}$ - O Anexo 11, acrescido ao Regulamento da Lei no. 997, de 31 de maio de 1976, pelo artigo $7^{\circ}$ do Decreto no. 50.753 , de 28 de abril de 2006, passa a vigorar conforme o Anexo que integra o presente decreto.

ANEXO 11- 1. Estão sujeitos ao critério de compensação, os novos empreendimentos e ampliações, cujo total de emissões adicionadas é igual ou superior a:

a) Material Particulado (MP): 100 t/ano 
b) Óxidos de Nitrogênio (NOx): 40 t/ano

c) Compostos Orgânicos Voláteis, exceto metano (COVs, não-CH4): 40 t/ano

d) Óxidos de Enxofre (SOx): 250 t/ano

e) Monóxido de Carbono (CO): 100 t/ano

2. Definições

a) emissões: liberação de substâncias para a atmosfera a partir de fontes pontuais ou difusas;

b) óxidos de Enxofre: óxidos de enxofre, expressos em dióxido de enxofre (SO2);

c) óxidos de Nitrogênio: óxido de nitrogênio e dióxido de nitrogênio, expresso em dióxido de nitrogênio (NO2);

d) Composto Orgânico Volátil (COV) Não- Metano: todo composto orgânico, exceto o metano ( $\mathrm{CH} 4)$, medido por um método de referência ou determinado por procedimentos estabelecidos pela CETESB. PROC. SMA-339-07

A exclusão dos empreendimentos e atividades automobilísticas e aeronáuticas, terminais e bases de armazenamento, carga e descarga de combustíveis e substâncias voláteis possibilita a isonomia no tratamento dos emissores uma vez que, com a adoção de lista positiva corre-se o risco de haverem atividades ou empreendimentos que não sejam contemplados, passando agora a ser os empreendimentos pertencentes à classe A da curva $\mathrm{ABC}$ definidas por subregião, quando da elaboração do inventário de fontes.

Espera-se assim, com essas alterações, que as análises de processos de licenciamento ambiental no Estado contemplem as características regionais, considerando o conjunto de fontes instaladas na região e que, por conseguinte afetam a qualidade do meio e não análises isoladas, visando a melhoria da qualidade do ar como um todo, sem prejuízo ao desenvolvimento econômico do Estado, como pressupõem os artigos $2^{\circ}$ e $3^{\circ}$ do Decreto Federal nº4.297/02:

Art. $2^{\circ}$ - O ZEE, instrumento de organização do território a ser obrigatoriamente seguido na implantação de planos, obras e atividades públicas e privadas, estabelece medidas e padrões de proteção ambiental destinados a assegurar a qualidade ambiental, dos recursos hídricos e do solo e a conservação da biodiversidade, garantindo o desenvolvimento sustentável e a melhoria das condições de vida da população.

Art. $3^{\circ}$ - O ZEE tem por objetivo geral organizar, de forma vinculada, as decisões dos agentes públicos e privados quanto a planos, programas, projetos e atividades que, direta ou indiretamente, utilizem recursos naturais, assegurando a plena manutenção do capital e dos serviços ambientais dos ecossistemas.

Parágrafo único- O ZEE, na distribuição espacial das atividades econômicas, levará em conta a importância ecológica, as limitações e as fragilidades dos ecossistemas, estabelecendo vedações, restrições e alternativas de exploração do território e determinando, quando for o caso, inclusive a relocalização de atividades incompatíveis com suas diretrizes gerais. 


\section{4- APLICAÇÃO DOS DECRETOS}

Neste capítulo os Decretos Estaduais $\mathrm{n}^{\circ} 48.523 / 04, \mathrm{n}^{\circ 50.753 / 06}$ e $\mathrm{n}^{\circ} 52.469 / 07$ são apresentados de forma aplicada e prática. Serão abordadas as questões referentes à implantação e aplicação da norma, bem como seus reflexos nos diferentes segmentos: institucional, empresarial, sociedade e com a apresentação do universo de empresas geradoras de energia abrangidas pelo decreto. O estudo de caso em geradores de energia elétrica, para uma Usina Termelétrica a Gás e uma Usina de Açúcar e Álcool com Cogeração será objeto de análise no capítulo cinco.

À partir de então, com as alterações realizadas no Decreto Estadual n ${ }^{\circ} 8.468 / 76$ promovidas

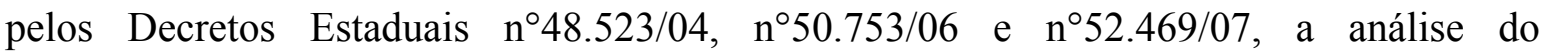
licenciamento ambiental no Estado de São Paulo prevê limite territorial no licenciamento de fontes fixas e móveis, na(s) área(s) saturada(s) ou em via de saturação sendo estes definidos pelos limites político administrativo dos municípios onde a fonte irá se instalar.

As áreas saturadas ou em vias de saturação são definidas através das concentrações dos poluentes específicos amostrados e as ultrapassagens dos PQAr (Padrões de Qualidade do Ar), através da análise de dados das séries históricas disponíveis no órgão de meio ambiente.

Entretanto, conforme visto no capítulo segundo, a formação de espécies, suas fontes e sua remoção da atmosfera (troposfera) são processo mais dinâmicos que, no entanto, para efeito de aplicação em licenciamento ambiental não apresentam significância temporal numa escala inferior ao ano, período de revisão da classificação das áreas saturadas, conforme é previsto atualmente pela legislação.

Os poluentes que promovem o desenquadramento da qualidade do ar de um município ou região, conferindo a condição de bacia saturada ou de bacia em via de saturação, tornandose elegíveis à geração de créditos são dos poluentes regulamentados, conforme exemplificado na figura 4.1 e que são: $\mathrm{CO}, \mathrm{NO}_{\mathrm{x}}, \mathrm{SO}_{\mathrm{x}}, \mathrm{MP}$ e $\mathrm{COV}$ exceto metano. Para o 
ozônio, a condição de saturação é dada para todos os municípios que, total ou parcialmente se encontrem a menos de $30 \mathrm{Km}$ de uma estação de monitoramento que gere dados válidos ao órgão de meio ambiente.

Estes poluentes são os mesmos que definem as linhas de corte para as empresa efetuarem a compensação compulsória de poluentes adicionados nas bacias saturadas e que fazem parte do PREA (Programa de Redução de Emissões Atmosféricas).

\section{Regiöes Saturadas}

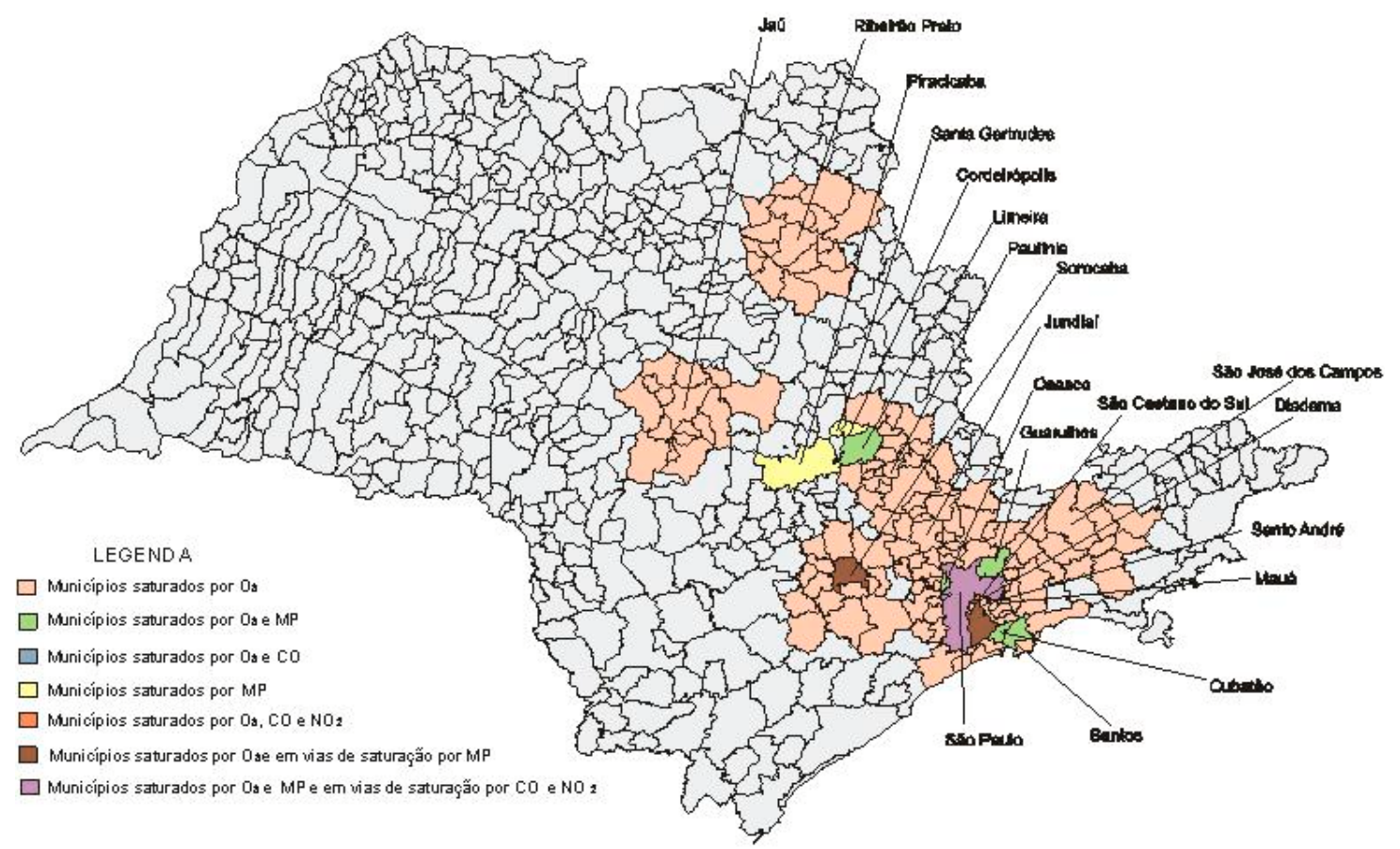

Figura 4.1- Situação de saturação dos municípios do Estado de São Paulo Fonte: CETESB (2007a)

CETESB (2007a) apresenta a divulgação das áreas saturadas e em vias de saturação no Estado de São Paulo para o ano de 2007, conforme a Figura 4.1. Salienta-se que um determinado município poderá estar saturado ou em vias de saturação para um ou mais poluentes, como no caso do município de São Paulo, que atualmente encontra-se saturada por $\mathrm{O}_{3}$ e $\mathrm{MP}$ e em vias de saturação para $\mathrm{CO}$ e $\mathrm{NO}_{2}$.

A quantidade e qualidade das estações de monitoramento instaladas e que geram dados válidos, os métodos de amostragem e localização destas para a definição das sub-bacias e poluentes em saturação e em vias de saturação são fatores de relevância no contexto do 
licenciamento. É importante mencionar que as atuais estações de monitoramento, automáticas e manuais seguem os preceitos de determinação de localização de estações de monitoramento estabelecidos internacionalmente, bem como os métodos utilizados pela CETESB para a qualificação e quantificação dos poluentes amostrados.

SMA (2007) prevê no projeto Respira São Paulo, como parte dos 21 Projetos Ambientais Estratégicos, a ampliação da quantidade das estações de monitoramento da qualidade do ar de 43 para 53 e o aperfeiçoamento das redes de monitoramento da qualidade do ar da CETESB, além da publicação do Inventário de Emissão de Poluentes, até dezembro de 2010, visando cobrir quase todo o território paulista e contemplando as principais regiões de interesse.

Para o gerenciamento destas áreas é importante o conhecimento do inventário de fontes de emissão da região (Relatório de Qualidade do Ar), dos padrões e taxas de emissão das fontes e dos mecanismos de compensação de emissão dos poluentes que tornam a sub-bacia Saturada (SAT) ou Em Via de Saturação (EVS) (Manual de operacionalização do Decreto Estadual $n^{\circ} 50.753 / 06$ ), principalmente para empreendimentos já licenciados (existentes) e integrantes do PREA - Programa de Redução de Emissões Atmosféricas.

O Inventário Estadual de Fontes de Poluição a ser implantado e anualmente atualizado, exigência feita pelo setor industrial paulista quando da revisão e aprovação do Decreto Estadual n52.469/07 deverá ser uma lista abrangente, por fonte de emissões de poluentes e de uma determinada área num tempo definido.

Segundo USEPA (1999), minimamente um Inventário de emissões deverá apresentar:

- Estimativa de emissões por categorias de fontes;

- Delimitação geográfica do inventário;

- Intervalo de tempo que represente as emissões;

- Dados operacionais, industriais e econômicos para estimar e alocar emissões; 
- Descrição das fontes (procedimentos de aquisição de dados, métodos de manipulação e cálculos dos dados, cópia dos questionários e resultados, citação de todos os fatores de emissão, documentação completa e hipóteses consideradas, identificação de fontes de emissão, lista de referências).

Os critérios, aproximações, métodos e considerações utilizados na sua elaboração deverão ser claramente identificáveis e também as forma de atualização e divulgação simplificadas e práticas, de forma a atender a regulamentação em vigor e que definirá a curva $\mathrm{ABC}$, bem como a condição de saturação dos municípios paulistas, bases para o PREA.

A figura 4.2 apresenta a esquemática de implantação do Decreto Estadual n $48.523 / 04$ com a configuração do licenciamento no Estado de São Paulo no que se refere a empreendimentos localizados em zonas saturadas e em vias de saturação e contribuintes com emissões passíveis de compensação (Decreto Estadual n50.753/06 e n52.469/07).

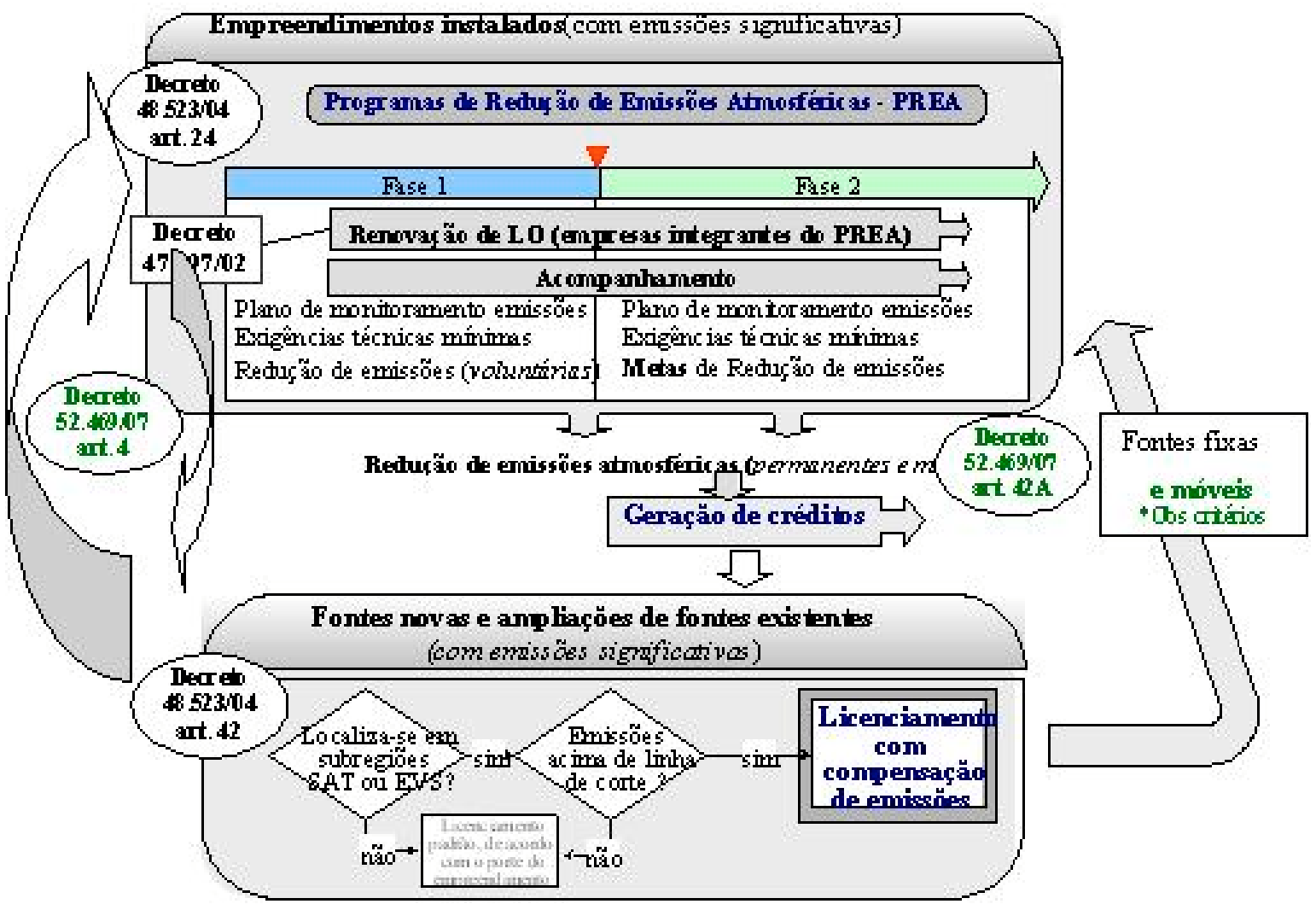

Figura 4.2- Esquema de operacionalização do Decreto Estadual $\mathbf{n}^{0} 50.753 / 06$ e suas alterações

Fonte: Elaboração própria 
Os geradores de energia elétrica, incluindo-se usinas de açúcar e álcool, termoelétricas, fábricas de biodiesel, refinarias de petróleo e outros empreendimentos que tenham emissões significativas em seus processos industriais, além de fontes móveis (frotas cativas) passam a ser licenciadas segundo a norma vigente (fontes novas e ampliação de fontes existentes). Já os empreendimentos existentes anteriormente à publicação dos Decretos e que tenham emissões significativas, isto é, acima da linha de corte estabelecida pela CETESB com base nas informações prestadas quando do cumprimento do Decreto Estadual n²7.397/02 passarão a integrar o rol de empresas pertencentes ao PREA e, compulsoriamente, deverão atingir as metas de redução de emissões estipuladas para a bacia aérea.

Entretanto, há um período de transição em que até o final de 2012 as empresas que promoverem tais reduções (ditas voluntárias) receberão créditos para os respectivos poluentes específicos abatidos e poderão comercializá-los na mesma bacia ou em bacia adjacente. Após o período de transição os critérios para concessão de créditos e utilização dos mesmos são diferenciados (outros fatores defletores e condições de utilização), conforme o texto legal alterado pelo Decreto Estadual n52.469/07.

Segundo CETESB (2006) as linhas de corte para emissão anual de poluentes regulamentados foram estabelecidas com base no New Source Review Prevention of Significant Deterioration and Nonattainment Area Permitting - (NSR/PSD/NAP/Workshop Manual), draft de Outubro de 1990 da EPA (Environmental Protection Agency) e nos inventários de emissões disponíveis na CETESB, definindo que as emissões anuais de fontes por poluentes regulamentados em toneladas são: 100 para MP; 40 para $\mathrm{NO}_{\mathrm{x}}, 40$ para COV exceto metano, 250 para $\mathrm{SO}_{\mathrm{x}}$ e 100 para CO.

Para as fontes fixas, considerando-se dois cenários: (A) para capacidade máxima de produção de uma indústria (Regime de operação de 365 dias/ano e 24 h/dia) e outros (B) para operação em dias úteis (Regime de operação de 240 dias/ano e 8 h/dia) têm-se os seguintes limites de emissão (tabela 4.1). 
Tabela 4.1- Limites de emissão segundo o regime de operação da fonte

\begin{tabular}{lccc}
\hline \multirow{2}{*}{ Poluente } & $\begin{array}{c}\text { Taxa emissão } \\
\text { (tiano) }\end{array}$ & \multicolumn{2}{c}{ Regime de operaçã̃o } \\
\cline { 3 - 4 } & 100 & 52 & normal $^{\mathrm{A}}$ \\
\hline MP & 40 & 20,8 & 11,4 \\
NOx & 40 & 20,8 & 4,56 \\
COVS (nẫoCH4) & 250 & 130 & 4,56 \\
SOx & 100 & 52 & 28,5 \\
CO & &
\end{tabular}

^- Regime de operaçẫo de 365diasiano e 24hidia

- Regime de operaçẫo de 240diasiano e 8hidia

Fonte: Elaboração própria

\section{1- Estimativa de emissões}

No levantamento das emissões veiculares, quer por motores ciclo otto ou ciclo diesel, há que se considerar primordialmente os seguinte parâmetros mínimos:

- Emissões evaporativas dos respiros, juntas e conexões do sistema de alimentação de combustível (para COV), dado em g/Km;

- Emissões geradas pelo processo de combustão, desgaste de pneus e pastilhas de freio ou lonas (para MP), dado em $\mathrm{g} / \mathrm{Km}$;

- Emissões de operação de transferência, por ocasião do abastecimento e uso do veículo (para COV), dado em \% em massa de combustível consumido.

O tipo/categoria de veículo (leve ou pesado), a deterioração da frota (ano de fabricação), a estimativa da quilometragem média percorrida anualmente são parâmetros a serem levantados.

Já para outros veículos leves, a CETESB utiliza-se dos valores de $60.000 \mathrm{Km} /$ ano para taxis de todas as idades, de $20.000 \mathrm{Km} /$ ano para cálculos de motocicletas de todas as idades, $80.000 \mathrm{Km} /$ ano para vans e ônibus e $42.000 \mathrm{~km} /$ ano para veículos de carga. 
O cálculo aproximado da emissão $(\mathrm{E})$, de um dado veículo é dado pelo fator de emissão característico da categoria do veículo (FE) e quilometragem média percorrida no período considerado (d):

$$
\mathbf{E}=\mathbf{F E} \times \mathbf{K m}
$$

onde: E: emissão $(\mathrm{g})$

FE: fator de emissão $(\mathrm{g} / \mathrm{km})$

d: distância $(\mathrm{Km})$

Para maior rigor neste cálculo é necessário considerar também o fator de deterioração da frota considerada $(\mathrm{Fd})$, que aumenta com o desgaste natural das peças do motor e da degradação dos componentes de controle de emissão, via de regra (ALVES Jr, 2006).

$$
\mathbf{E}=\mathbf{F E}(0 \mathrm{k}) \times \mathbf{F d} \times \mathbf{d}
$$

onde: $\mathrm{FE}(0 \mathrm{k})$ : Fator de emissão do veículo novo

Fd: Fator de deterioração da frota (adimensional).

Para o cálculo das emissões de frotas cativas é necessário considerar escalonadamente os veículos que a compõem, o ano-modelo (j) de cada um registrada no DETRAN (N).

$$
E=\Sigma[F E(0 k) \times F d \times N(j) \times d] \text { para cada ano }
$$

onde: N: número de veículos da frota

A prática recomenda a regulagem dos motores e a instalação de catalizadores e retrofites para redução das emissões veiculares. É claro que medidas não tecnológicas também respondem pela redução das emissões, como uso de bicicletas, transporte solidário e transporte de massa, por exemplo.

O Estado ainda carece de um programa específico que contemple a redução das emissões veiculares já em uso, uma vez que o PROCONVE e do PROMOT são programas notadamente para veículos novos.

Para as fontes fixas, empreendimentos integrantes do PREA (anexo 3) as emissões terão de ser reduzidas utilizando sistemas de controle da poluição do ar baseados na melhor tecnologia prática disponível (MTPD ou BAT: Best Available Technology) e 
implementando Plano de Monitoramento das Emissões Atmosféricas, segundo Termo de Referência estabelecido pela CETESB.

Assim como nas emissões veiculares, as emissões oriundas de fontes fixas também fazem uso de fatores de emissão de acordo com o tipo de combustível utilizado, as características de redução de emissões do equipamento de controle e proteção (ECP) e a intensidade do uso (T), conforme observado na equação 8 para cada poluente (EPA, 2008):

$$
E=(F E x T) \times[1-E C P / 100]
$$

onde: FE: Fator de emissão do veículo novo $(\mathrm{g} / \mathrm{h})$

ECP: Equipamento de Controle e Proteção (\%)

T: intensidade de uso (h).

O cálculo das emissões totais da planta utiliza-se a soma de todas as emissões pontuais (equação 8), além das emissões provenientes de fonte fugitivas, evaporativas e de processos de transferência de combustíveis que possam existir para um dado poluente.

Alteração de matérias-primas, de combustível, de processo industrial também constituem medidas que promovem redução de emissões de poluentes atmosféricos em fontes fixas pois baseiam-se no princípio da não-geração do poluente.

\section{2- Técnicas de redução de emissões atmosféricas}

As técnicas de redução das emissões variam de acordo com o tipo de poluente, características fisico-químicas e estado físico, utilizando-se de processos físico-químicos ou mesmo biológicos para a promoção da redução de seus remanescentes.

Assim, as alternativas de equipamentos de controle de poluição do ar a serem adotados por fontes fixas para redução das emissões de poluentes são, conforme CETESB (2003): 


\section{a- Para Material Particulado:}

a.1- Sistemas secos: coletores gravitacionais, coletores mecânicos inerciais, coletores centrífugos, precipitadores eletrostáticos e filtros de tecido;

a.2- Sistemas úmidos: lavadores pré-atomizados, lavadores com atomização pelo gás, lavadores com enchimento e precipitadores eletrostáticos úmidos.

\section{b- Para Gases e Vapores:}

Condensadores, absorvedores, incineradores térmicos e catalíticos, biofiltros e processos especiais.

Para o caso específico do poluente $\mathrm{NO}_{\mathrm{x}}$, o uso de combustíveis com baixos teores de nitrogênio, projetos de caldeiras e motores de combustão interna prevendo diminuição das câmaras de combustão, queima em estágios, uso de queimadores Low- $\mathrm{NO}_{\mathrm{x}}$, são os mais indicados.

A tabela 4.2 apresenta as principais técnicas de controle e redução do $\mathrm{NO}_{\mathrm{x}}$ de fontes fixas disponíveis conforme métodos baseados na sua não-formação ou remoção, bem como a eficiência aproximada destes, que variam caso a caso em virtude de características fisicoquímicas e particularidades dos processos industriais.

\section{Tabela 4.2- Principais técnicas de controle e redução do $\mathrm{NO}_{\mathrm{x}}$}

\begin{tabular}{|c|c|c|}
\hline METODO & EQUIPA MENTO /TECNICA & EFICIENNCIA \% \\
\hline $\begin{array}{l}\text { Redução d temperatura de pico } \\
\text { - Evitar a razâo estequiométrica } \\
\text { - Muistura combustivel } 02 \text { apropriada } \\
\text { - hjeçẫo de gás fio como combustivel } \\
\text { - hjeção de água ou vapor }\end{array}$ & $\begin{array}{l}\text { Recirculaçấo de Gases } \\
\text { Requeima com Gás Natural } \\
\text { Queimadores Low-Nox } \\
\text { Otimizaçâo da Combustão } \\
\text { Menos Excesso de Ar } \\
\text { Injeçẫo de Agua Ou Vapor } \\
\text { Ar de Pré-Aquecimento Reduzido } \\
\text { Combustâo Catalítica }\end{array}$ & 50 a 70 \\
\hline $\begin{array}{l}\text { Redução do tempo de residencia na temperatura de pico } \\
\text { - Controle de queima em motores de combustão intema } \\
\text { - Reduçẫo da câmara de combustấo (dimensionamento) }\end{array}$ & $\begin{array}{l}\text { Injetar Ar em Etágios } \\
\text { Injetar Combustível em Estágios } \\
\text { Injetar Vapor }\end{array}$ & 50 a 70 \\
\hline $\begin{array}{l}\text { Redução química do } \mathrm{NOx} \\
\text { - Remoção de } 02 \text { dos óxidos de nitrogênio } \\
\text { - hjeçấo de agentes redutores } \\
\text { - Maçaricos apropriados }\end{array}$ & $\begin{array}{l}\text { Requeima de Combustivel } \\
\text { Maçaricos Low-NOx } \\
\text { Reduçẫo Catalítica Seletiva } \\
\text { Reduça Catalítica Nấo Seletiva }\end{array}$ & 35 a 90 \\
\hline $\begin{array}{l}\text { 0xidação com subsequente absorção } \\
\text { - Catalizador oxidante de } \mathrm{N03}\end{array}$ & $\begin{array}{l}\text { Reator a Plasma } \\
\text { Injeção de 0xidante }\end{array}$ & 60 a 80 \\
\hline Uso de abscrvertes & $\begin{array}{l}\text { Injeç̃̃o na Câmara de Combustâo } \\
\text { Injeçẫo nos Dutos }\end{array}$ & 60 a 90 \\
\hline $\begin{array}{l}\text { Remos ão do ritrogênio } \\
\text { - Re dizir a forma çقo de NOx }\end{array}$ & $\begin{array}{l}\text { Oxigênio ao h vés de Ar } \\
\text { Combustivel com Teor de Nitrogênio Ultra Baixo }\end{array}$ & variá vel \\
\hline Combiração de métodos & & variáa vel \\
\hline
\end{tabular}

Fonte: CETESB (2007b), Dias (2007) e elaboração própria 
O princípio básico das técnicas de não formação de $\mathrm{NO}_{\mathrm{x}}$ está na obtenção da proporção mais próxima da proporção estequiométrica na queima do combustível na câmara de combustão, isto é, na zona de queima dos maçaricos.

O controle dos parâmetros da combustão, tais como temperatura, tempo de residência, geometria da câmara de combustão, quantidade de nitrogênio do combustível e do ar utilizado são fatores que influenciam na formação do $\mathrm{NO}_{\mathrm{x}}$ e as técnicas para redução destes baseiam-se nesses conceitos.

A injeção de água ou vapor na câmara de combustão minimiza a formação de NOx térmico em turbinas, devido a alta temperatura da chama. Entretanto seu posicionamento incorreto acarreta formação de $\mathrm{NH}_{3}$ em excesso.

Outra técnica é a combustão com combustores tipo Low- $\mathrm{NO}_{\mathrm{x}}$ e Dry Low- $\mathrm{NO}_{\mathrm{x}}$ que privilegiam a distribuição aerodinâmica e correta mistura ar-combustível, de forma a diminuir a formação de $\mathrm{NO}_{\mathrm{x}}$ térmico através da redução da temperatura de chama reduzida e tempo de residência reduzido à temperatura de pico, além da diminuição do $\mathrm{NO}_{\mathrm{x}}$ combustível (devido a injeção reduzida de $\mathrm{O}_{2}$ na zona de combustão primária).

A injeção de ar comprimido com gás faz a pré-mistura extinguir as zonas quentes mas que necessitam de um projeto específico de câmara de mistura e da zona de entrada, para evitar o retorno da chama (flashback).

Para os processos de pós-combustão, destacam-se a Redução Catalítica Seletiva com a utilização de amônia na presença de catalizador para redução dos óxidos de nitrogênio em $\mathrm{N}_{2}$ e água e a Redução Não Catalítica Seletiva que utiliza-se uréia $\left[\mathrm{CO}\left(\mathrm{NH}_{2}\right)_{2}\right]$ de forma não seletiva para a redução e formação de $\mathrm{N}_{2}$ e água. 
Os processos de recirculação de gases, requeima, injeção de ar e de combustível em estágios, utilização de combustível com baixos teores de $\mathrm{N}_{2}$ e utilização de $\mathrm{O}_{2}$ ao invés de ar são outras medidas adotadas para a minimização da formação de $\mathrm{NO}_{\mathrm{x}}$.

A figura 4.3 que se segue mostra um queimador tipo ultra $\mathrm{Low}-\mathrm{NO}_{\mathrm{x}}$ de um determinado fabricante, onde o desenho do queimador, aliado à correta injeção de ar (próximo da razão estequiométrica) privilegiando locais onde não há zonas de formação de $\mathrm{NO}_{\mathrm{x}}$ Ativo nas zonas internas e externas de recirculação e zona rápida de mistura.

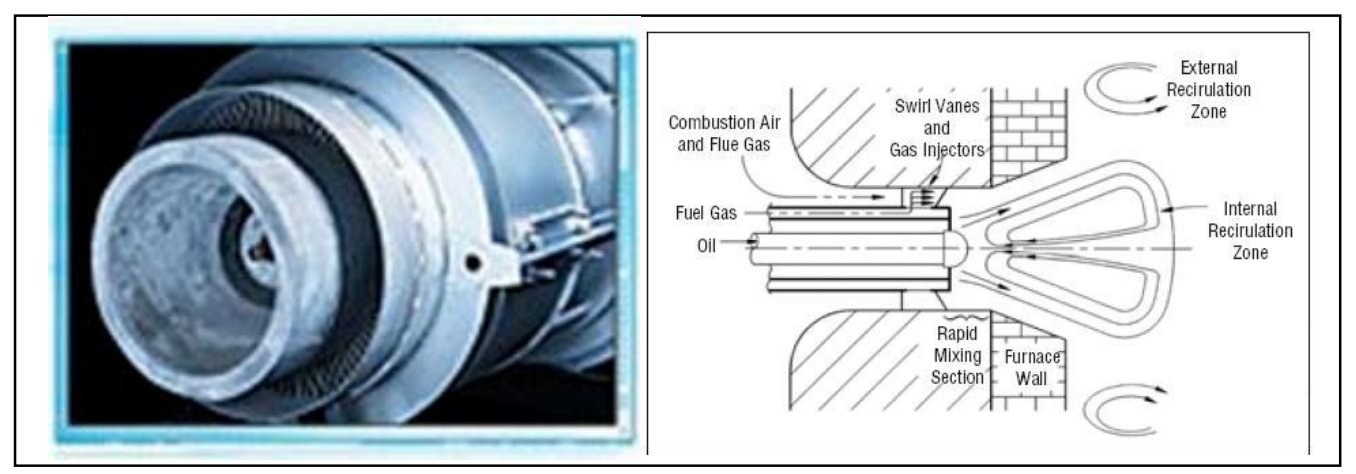

Figura 4.3- RMB queimador ultra Low-NOx

Fonte: ZOHN ZINK (2008)

Assim, notadamente para emissões de $\mathrm{NO}_{\mathrm{x}}$ de processos de queima em caldeiras recomenda-se o uso de queimadores Low-NO $\mathrm{N}_{\mathrm{x}}$. Segundo a ARB (2007), a redução significativa de $\mathrm{NO}_{\mathrm{x}}$ nas bacias aéreas saturadas na Califórnia para esses poluentes se deu pela utilização de ultra-Low $\mathrm{NO}_{\mathrm{x}}$ burners, possibillitando diminuição da contribuição deste poluente na atmosfera.

A redução dos COV se dá primordialmente pelo confinamento de forma a se evitar sua volatilização à atmosfera. A prática recomenda a utilização de catalizadores em veículos automotores e a adequação de tanques de estocagem de combustíveis em tanques com teto apropriados e pintura que diminua os efeitos da insolação (evaporação). Já nos processos de transferência de combustíveis há uma série de recovers e para postos de gasolina os sistemas de recuperação de vapores orgânicos.

Segundo o próprio manual de aplicação do Decreto Estadual $n^{\circ} 50.753 / 06$, se for implantado um sistema de recuperação de vapores orgânicos, para cada litro de gasolina 
comercializado, deixará de ser emitido para a atmosfera cerca de 1,3 grama de compostos orgânicos voláteis (COVs), precursores da formação de ozônio troposférico na atmosfera. Considerando que todos os COVs emitidos na transferência dos combustíveis são hidrocarbonetos não-metano $\left(\mathrm{HCs}\right.$ não- $\left.\mathrm{CH}_{4}\right)$, num posto com 8 bombas e quatro tanques subterrâneos, com movimento anual de 2 milhões de litros, poderão ser obtidos créditos de emissões de 2,6 toneladas de COVs por ano (CETESB, 2006).

\section{3- Reflexos da Implementação dos Decretos}

\subsection{1- Institucional}

Externa e internamente ao sistema de meio ambiente surgiram demandas em resposta às aprovações ocorridas na legislação ambiental no Estado de São Paulo.

O mercado, entendido aqui como sendo as indústrias, os fabricantes de equipamentos, as empresas prestadoras de serviços (de engenharia e de consultoria especializada) e assessorias jurídicas, excetuando-se os órgãos governamentais e sociedade civil demandaram de informações sobre o tema, tanto questões técnicas quanto administrativas (procedimentos para licenciamento) e posicionamento jurídico.

A procura por capacitação específica sobre as questões trazidas pelos Decretos também constituíram-se como outra demanda e que, foi percebido nos órgãos de meio ambiente um aumento nos pedidos de análises de pareceres técnicos e de licenciamento, acerca da viabilidade da instalação de fontes de poluição em áreas saturadas e possibilidade de geração de créditos de poluentes específicos através da possível redução de emissão destes.

Em resposta às novas solicitações deste mercado em formação, onde as demandas dos atores (players) concentravam-se inicialmente no acesso a informação, os órgãos de meio ambiente da Secretaria de Estado do Meio Ambiente realizaram ações no sentido de tornálo mais confiável e público. Disponibilização da legislação completa e do manual de operacionalização do Decreto $\mathrm{n}^{\circ} 50.753 / 06$ no site, revisão de procedimentos para licenciamento e exigências técnicas para análise dos documentos instrutórios nos pedidos de licenciamento, além da criação de cursos de capacitação ao público externo, 
notadamente pessoas não pertencentes ao sistema de Meio Ambiente do Estado de São Paulo.

Isso posto, a necessidade de maior capacitação do corpo técnico ambiental foi um primeiro reflexo das alterações promovidas na legislação e sentidas pelo nos órgãos licenciadores do Sistema de Meio Ambiente.

O posicionamento dos órgãos ambientais sobre os "casos especiais" que requerem revisão da norma ou a adoção de instrução técnica específica. Casos de menor importância quando analisados à luz do montante de emissões globais que o empreendimento possa emitir e também casos de atividades não previstas no licenciamento convencional e que, por serem emissoras de poluentes em áreas restritas necessitam de pareceres ou mesmo de licenciamento. Como exemplo tem-se as atividades de geração de energia elétrica através de geradores estacionários operando em horário de pico o ano todo (geração não emergencial) em shoppings centers ou geração de energia através de duas fontes de combustível distintas em um mesmo empreendimento (gás natural e óleo combustível), como questionado por uma Usina Termoelétrica na região metropolitana de São Paulo.

A elaboração e do inventário estadual de fonte de poluição também constitui-se em uma demanda avinda da alteração da legislação ocorrida em 2007 (Decreto Estadual $\mathrm{n}^{\circ}$ 52.469/07) que prevê a elaboração da curva $\mathrm{ABC}$ e, por conseguinte definição das empresas que participarão do PREA.

Adicionalmente a necessidade de estabelecimento de um operador econômico externo, uma bolsa de ações e certificados que possa disciplinar esse futuro mercado de créditos de poluentes específicos.

\subsection{2- Empresarial}

Para levantamentos das informações do setor empresarial foram consultados os registros de atendimento da CETESB por e-mail e através de contato telefônico recebidos pelo setor de 
licenciamento da Diretoria de Controle, além de entrevistas a empresários e consultores do segmento.

Notou-se que, aos empreendimentos de baixo potencial dificilmente o tema era de conhecimento prévio (declaração expontânea e induzida). Já os de grande potencial de poluição notou-se que alguns casos as empresas já haviam tomado conhecimento das alterações, ou por terem sido exigidas complementações das informações pela CETESB/SMA, ou por terem alguns de seu funcionários fazendo parte dos treinamentos já realizados pelo setor de capacitação e de emissões da casa.

Já para as consultorias mais afeitas ao tema buscaram se inteirar do tema, sobre a forma de interpretação do texto legal e sistemática de sua aplicação.

Também fabricantes de equipamentos fizeram consultas ao órgão ambiental no sentido de obter informações sobre emissões para aplicá-los na eficiência de seu produtos - quando aplicado a instalação de caldeira e dimensionamento de equipamentos.

Escritórios de advocacia também perceberam, assim como algumas consultorias que tratase de uma excelente oportunidade de negócio, atribuindo às reduções o título de Créditos de Emissões Atmosféricas Reduzidas (CEAR's) e a este mercado de créditos o nome de Mercado Paulista de Emissões Atmosféricas (MPEA). Para SOLER (2006) “Os CEAR's são instrumentos de mercado que visam garantir eficiência econômica ambiental no controle da poluição do ar, estimulando novas fontes de emissão a pagar pelo "direito de poluir" pela via reflexa da distribuição de encargos às fontes existentes, as quais passarão a investir em tecnologias modernas e limpas para gerarem créditos e posteriormente colocálos no mercado".

Vale mencionar que, durante a pesquisa fizeram-se marcantes e dignos de registro alguns fatos que, parecem refletir o que ocorre neste segmento e em qualquer outro segmento da área ambiental. A postura empresarial ainda é de desconfiança com relação às consultorias 
que o representam e submetem estudos ao órgão de meio ambiente, provocando enormes atrasos na análise dos processos de licenciamentos devido à falta de informações nos estudos de emissão.

Outro fato recorrente foi a qualidade dos estudos apresentados que se mostraram extremamente pobres e sem conteúdo técnico mínimo, com erros crassos de adição e de transformação de unidades de medida. Falta de confiança do setor empresarial quanto à disponibilização de informações ao órgão de meio ambiente também é fato que provoca atrasos e morosidade nos processos de licenciamento ambiental.

Em suma, a legislação trouxe aos empreendimentos a necessidade de estudos mais especializados para obtenção de suas licenças ambientais no Estado de São Paulo. A reboque um mercado extremamente promissor para empresas, prestadores de serviços e fabricantes de equipamentos, sem falar é claro na possibilidade de ganhos efetivos na redução da poluição sem a utilização do instrumento punitivo de comando e controle. Cabe o amadurecimento da conscientização dos atores deste novo mercado no sentido de utilizarse desta ferramenta desburocratizada e de baixo custo.

\subsection{3- Sociedade}

As consultas à Internet geraram como cenário poucos artigos publicados, sendo que não haviam informes à população do órgão ambiental (à exceção do Manual de Operacionalização do Decreto Estadual nº50.753/06).

Assim, o tema é de conhecimento restrito dos mais interessados. Consultores e agentes públicos de meio ambiente de outros Estados têm buscado capacitação e maneiras de aplicá-los em seus Estados.

A melhora do site da CETESB e da SMA podem ser um alavancador na difusão das informações das bacia aéreas e sua condição de saturação ou não. Tal medida possibilitaria o atingimento de uma gama muito maior de cidadãos que, via de regra não estão em contato 
direto com o tema. Vale lembrar que o direito à informação é garantido pela Constituição Federal, Artigo $5^{\circ}$, inciso XXXIII e também pela Resolução SMA n66/96, no que tange às consultas a processos de licenciamento ambiental.

Já a consolidação do Mercado de Créditos pela redução das emissões deverá ser atribuído a um por órgão ou instituição que confira credibilidade e transparência ao processo de transferência de direitos sobre os créditos, em consonância com a legislação de proteção do meio ambiente federal e estadual e o Código Civil Brasileiro, cabendo ao órgão ambiental a desburocratização no mecanismo de Compensação de Emissões.

Segundo Seara Filho $(2008)^{5}$ a classificação das sub-regiões será aprovada pelo CONSEMA, criado em 1983 garante a participação dos órgãos do Governo e da sociedade civil (ONGs, SBPC - Sociedade Brasileira para o Progresso da Ciência, Organizações de Classe, Procuradoria Geral do Estado, Federação das Indústrias e Universidade) através de seus 36 membros em plenárias acaloradas promovendo o amplo debate das questões analisadas. (informação verbal)

As discussões atingem elevado grau técnico uma vez que os membros do conselho estão atentos às alterações na qualidade ambiental no Estado, principalmente no que se refere à questão do ozônio (SEARA FILHO, 2008).

A população espera primordialmente que, seja pela adoção de créditos, seja pela inclusão obrigatória no PREA a melhora efetiva da qualidade do ar em seus municípios e a garantia de que, sejam minimamente atingidos os padrões de qualidade do ar adotados.

Seja no nível institucional, empresarial ou mesmo na sociedade há uma evidência de falta de conhecimento amplo das condicionantes e benefícios destas novas legislações paulista.

\footnotetext{
${ }^{5}$ SEARA FILHO, G.: Secretário Executivo do CONSEMA.
} 
Interna e externamente ao órgão ambiental uma maior capacitação dos atores diretamente ligados ao tema é salutar para a melhoria global do mercado.

A maior divulgação das informações sobre o licenciamento ambiental em áreas saturadas é condição sine-qua-non para o impulso da aplicação da legislação. Consultas à qualidade do ar das bacias aéreas dos municípios através de mapas, informes de créditos gerados e disponíveis por região, poluente e validade dos mesmos, atendendo o Decreto Estadual n52.469/07 e legitimando a transparência com reação ao acesso à publicidade das informações do sistema de meio ambiente. Trata-se de uma medida fácil e de implantação quase que imediata que promove enormemente a implantação e consolidação da legislação no licenciamento ambiental paulista, nos vários níveis mencionados.

\section{4- Reflexos nos geradores de energia}

O decreto aplica-se a todos os empreendimentos geradores de poluentes regulamentados, em áreas saturadas e em áreas em via de saturação. São potenciais emissores de poluentes atmosféricos regulamentados e empreendimentos geradores de energia no Estado de São Paulo, entendendo-se como potenciais os empreendimentos cujas emissões de ozônio troposférico possam superar os limites estabelecidos pelo decreto e que são: indústrias petroquímicas, usinas de açúcar e álcool (UAA), termoelétricas (UTE), cogeradores de energia, usinas de biocombustíveis (UBC) e bases de armazenamento e transferência de combustíveis.

Quer pela emissão de poluentes à atmosfera devido principalmente ao processo de queima de combustíveis sólidos, líquidos ou gasosos, quer pela estocagem de combustíveis líquidos (hidrocarbonetos principalmente) que podem se volatilizar e, encontrando condições favoráveis, conforme mencionado na seção 3.3.1, formando o ozônio troposférico, um dos principais problemas de poluição do ar no Estado de São Paulo.

Os principais critérios para a seleção dos empreendimentos com maior potencial poluidor, quando a análise se der para ozônio troposférico são: 
- Combustível Utilizado;

- Fontes emissoras principais;

- Atividade poluidora (atividade da empresa).

A tabela 4.3 reflete as informações recebidas pelo sistema de meio ambiente quando do atendimento do Decreto Estadual n47.397/04 e mostra a relação de empreendimentos no Estado segundo seu porte, tipo e quantidade de combustível que se utilizam para suas atividades industriais.

\begin{tabular}{|c|c|c|c|c|}
\hline Empresas & $M E-E P P^{*}$ & Combustível Utilizado & Toneladasisno & Densidade adotada \\
\hline 20 & 5 & álcool & 270.578 .538 & $0,93 \mathrm{~g} k \mathrm{~m} 3\left(\mathrm{a}_{20}^{\circ} \mathrm{C}\right)$ \\
\hline 299 & 35 & bagaço de cana & 4.760 .854 .276 & $150 \mathrm{~kg} / \mathrm{m} 3$ (umidade 20 a 30 \% peso) \\
\hline 30 & 10 & carvấo ooque & 157.066 .029 & $700 \mathrm{Kgkm} 3\left(\mathrm{a} 20^{\circ} \mathrm{C}\right)$ \\
\hline 89 & 49 & carvẫo vegetal & 925.076 & $500 \mathrm{Kghm} 3$ (umidade 10 \%peso) \\
\hline 8 & 0 & cascas de arroz & 614.890 & $140 \mathrm{Kghm} 3$ (umidade $15 \%$ peso) \\
\hline 844 & 431 & cavacos de madeira & 7.579 .977 .367 & $250 \mathrm{~kg} k 33$ (umidade 20 a 30 \%peso) \\
\hline 5603 & 2114 & gás liquefeito de petróleo & 4.882 .926 .974 & $2,1 \mathrm{~kg} \ln 3\left(\mathrm{a}_{20} \mathrm{C}\right)$ \\
\hline 1263 & 124 & gás natural & 64.398 .128 .026 & $0,6 \mathrm{Kg} \operatorname{m} 3\left(\mathrm{a}_{20} \mathrm{C}\right)$ \\
\hline 79 & 23 & gás de refinaria & 1.102 .198 .900 & $0,82 \mathrm{Kg} / \mathrm{m} 3\left(\mathrm{a} 20^{\circ} \mathrm{C}\right)$ \\
\hline 4628 & 704 & óleo: diesele combustível & 2.798 .204 .807 & $0,70 \mathrm{Kg} /\left(\mathrm{a} 4^{\circ} \mathrm{C}\right)$ \\
\hline 17 & 4 & querozene & 6.313 & $080 \mathrm{Kg} /\left(\mathrm{a} 4^{\circ} \mathrm{C}\right)$ \\
\hline 115 & 60 & serragem & 15.694 .267 & $1100 \mathrm{~kg} / \mathrm{m} 3$ (umidade 10 qpeso) \\
\hline
\end{tabular}

*ME - Micro Empresa; EPP - Empresa de P equeno P orte

Fonte: CETESB (2008)

Em um primeiro estudo destes empreendimentos, não seriam objeto de análise aqueles considerados Micro Empresas ou Empresas de Pequeno Porte (ME ou EPP), embora tal critério é dado segundo as características de faturamento destes junto à Secretaria da Fazenda.

Além do tipo de combustível utilizado, a fonte poluidora (máquina ou equipamento) utilizado no processo de combustão também é de suma importância para o cálculo das emissões de poluentes (principalmente de $\mathrm{NO}_{\mathrm{x}}$,) visto que cada equipamento apresenta taxas de emissão diferenciadas. Um dos principais equipamentos utilizados pelo geradores de energia no Estado são caldeiras: à óleo, á gás, à lenha e etc. Há licenciadas 1.558 caldeiras no Estado atualmente CETESB (2008). Já para o caso de emissores de COVs, os tanques de armazenamento (teto fixo, flutuante, etc) são os principais emissores destes poluentes. 
Além do tipo de combustível utilizado/estocado e dos equipamentos utilizados nas plantas, a atividade poluidora é outro critério de seleção e que, no caso particular dos geradores de energia no Estado de São Paulo constituem-se principalmente de Usinas de Açúcar e Álcool (UAA), Usinas Termoelétricas (UTE) e Usinas de Biocombustíveis (UBC).

Tabela 4.4- Principais geradores de energia no Estado de São Paulo e emissão de precursores de ozônio troposférico

\begin{tabular}{cccccc} 
Empreendimento & Quantichade & Producão & Combustivel Utilizado & Emissão Principal & Poluente \\
\hline UAA & 134 & açúcar e áloool & bagaço de cana & caldeiras \\
UTE & $3^{*}$ & energia elétrica & gás natural & caldeiras e turbinas & NOx \\
UBC & 12 & biodiesel & óleo combustível & parque de tancagem & CoV \\
\hline
\end{tabular}

Fonte: CETESB (2008) e DAIA (2008)

No capítulo quinto, como objeto de estudo de caso foram escolhidas a Usina Santo Antônio de Açúcar e Álcool com cogeração de energia elétrica em Sertãozinho e a Capuava Energy Usina Termelétrica à gás natural e de Processo em Santo André, devido características de processo, regionais e da matriz energética do país, além das condição de saturação das bacias aéreas locais por ozônio. 


\section{5- ESTUDO DE CASO}

Para a escolha dos estudos de caso deste trabalho utilizaram-se como critérios: a condição de bacia saturada ou em vias de saturação para ozônio troposférico e a presença de geradores de energia que tenham processo de queima em seu processo produtivo, promovendo assim a emissão de poluentes que os decretos fazem menção e restrição.

Considerou-se também a aplicação do decreto no âmbito de 2 bacias aéreas diferentes, quer por características geográficas, quer por vocação industrial. Assim foram escolhidas a Usina Termoelétrica Capuava, localizada no município de Santo André, com o gás natural como combustível e a Usina Santo Antônio de Açúcar e Álcool, localizada no município de Sertãozinho, com a utilização do bagaço de cana-de-açúcar como combustível, em regime de cogeração.

\section{1- Usinas Termoelétricas a Gás Natural}

Termoelétricas são unidades térmicas e hidrelétricas que, utilizando-se de uma fonte combustível geram energia elétrica e que, utilizam a água como meio de transferência de calor. A energia elétrica é obtida a partir de uma série de conversões de energia que iniciase com a transformação da energia química do combustível (gás natural) em energia térmica que é transferida a um fluido de trabalho. Este, mediante sua expansão em uma turbina (a gás) transforma-se em energia mecânica de rotação e, conseqüentemente em energia elétrica por meio da ação eletromagnética em um gerador elétrico acoplado à turbina, constituindo-se o ciclo Bryton.

Os componentes principais de uma UTE a Gás Natural são: Compressor, responsável pela captação de ar atmosférico; Sistema de combustão, que o comprime à pressão de cerca de 13 bar e temperatura de $375^{\circ} \mathrm{C}$, que se eleva a $1.250^{\circ} \mathrm{C}$ com a queima do gás; A turbina onde a expansão com a queima do gás que aciona a turbina, reduzindo-se a pressão à atmosférica e temperatura a cerca de $550^{\circ} \mathrm{C}$ nos gases de exaustão. 
$\mathrm{O}$ ar atmosférico é continuamente succionado pelo compressor, onde é comprimido para uma alta pressão. $\mathrm{O}$ ar comprimido entra na câmara de combustão (ou combustor), é misturado ao combustível (gás natural) e ocorre a combustão, resultando em gases com alta temperatura. Os gases provenientes da combustão se expandem através da turbina e descarregam na atmosfera (gases de exaustão).

Parte do trabalho desenvolvido pela turbina é usado para o acionamento do compressor, sendo o restante utilizado para acionar o gerador elétrico, conferindo rendimento térmico entre 35 a $40 \%$ ao sistema.

A figura 5.1 apresenta um diagrama esquemático do funcionamento de uma central termoelétrica a gás natural com os equipamentos principais para geração de energia em ciclo simples e aberto:

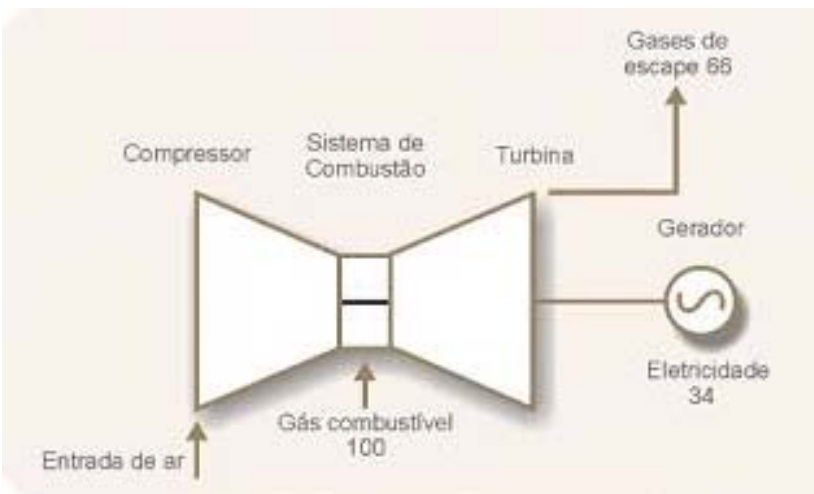

Figura 5.1- Diagrama esquemático de uma central termoelétrica a gás natural Fonte: REIS (1998)

\subsection{1- Usina Capuava Cogeração}

O empreendimento está localizado na Região Metropolitana de São Paulo, região administrativa com a maior densidade demográfica do Estado $\left(2.278,6 \mathrm{hab} / \mathrm{km}^{2}\right)$, e será instalado na Região do Grande $\mathrm{ABC}$, no município de Santo André. Tem como características principais: a alta densidade populacional, alta diversidade no parque industrial, bom sistema de transporte, um cenário acentuado de degradação dos recursos hídricos, do uso e ocupação do solo e da qualidade do ar. 
Com grande diversidade e articulação, o setor financeiro, a indústria, o comércio e os serviços, a Região Metropolitana de São Paulo contribuem sobremaneira para a economia do Estado.

Região de Proteção de Mananciais, Santo André apresenta 54,1\% do seu território protegido por APP, segundo legislação específica da década de 70, mas com eficácia discutível nos dias atuais uma vez que, muito embora o zoneamento industrial tenha evitado o adensamento do parque industrial na região, a ocupação do solo se deu de forma descontrolada.

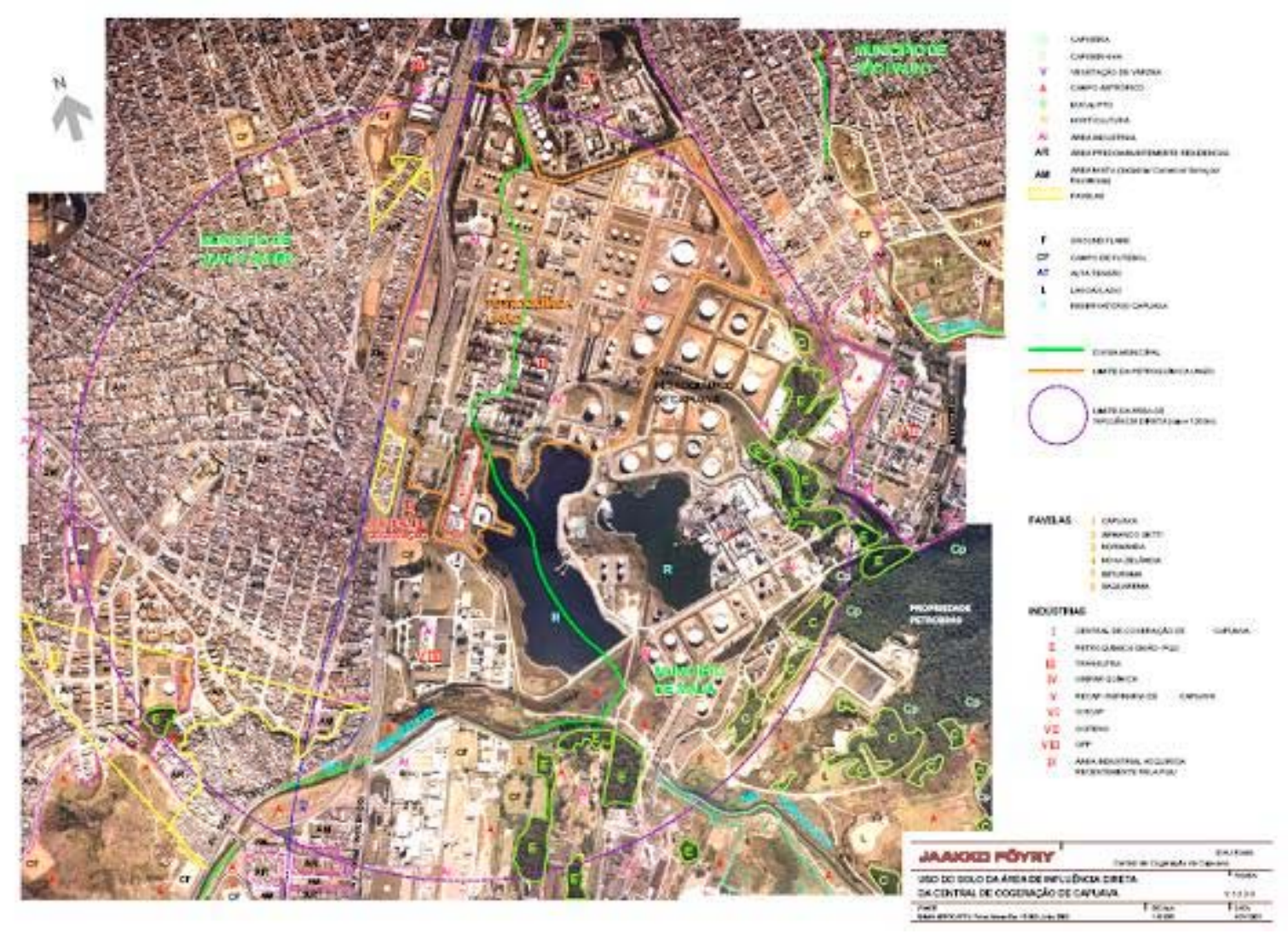

\section{Figura 5.2- Entorno da UTE Capuava Cogeração}

Fonte: JAAKKO PÖYRY ENGENHARIA LTDA - Relatório de Impacto Ambiental-Capuava Cogeração (2000)

A figura 5.2 apresenta a enorme pressão antrópica nas proximidades do pólo petroquímico de Capuava, sendo que na região há licenciados cerca de 147 empreendimentos das mais variadas atividades, sendo 115 deles de médio e grande porte, caracterizando-se por ser uma região de vocação regional industrial concentrando um grande parque industrial. 
Em CETESB (2007), a evolução das médias máximas de 1 hora de ozônio é mostrada na figura 5.3, apresentando o comportamento da poluição por ozônio troposférico na região metropolitana.

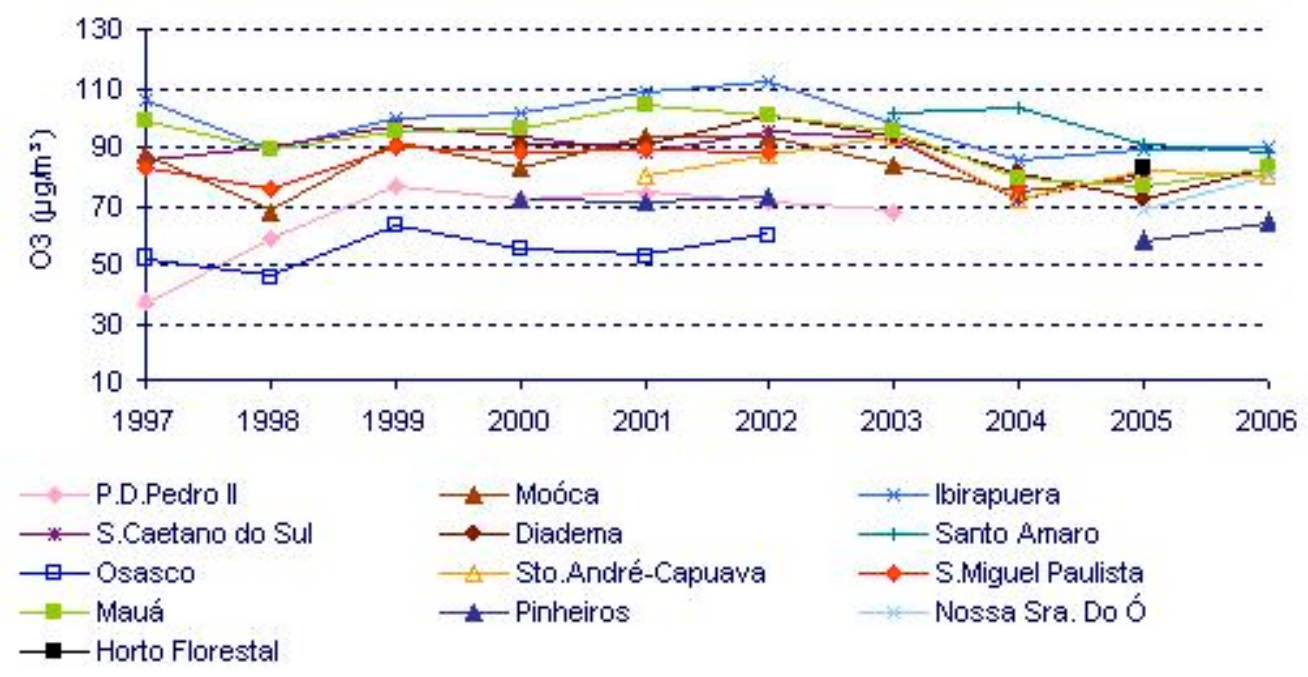

Figura 5.3- Evolução das concentrações médias anuais das máximas diárias - RMSP (médias de 1 hora)

Fonte: CETESB 2007

Segundo os critérios atualmente vigentes para classificação das sub-regiões, a região do ABC encontra-se classificada como Saturada com grau de severidade sério $\left(212,67 \mu \mathrm{g} / \mathrm{m}^{3}\right.$ -

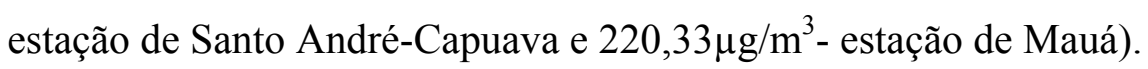

A figura 5.4 apresenta a comparação do padrão de qualidade do ar obtido em 2006 em comparação com o recomendado pela legislação. 


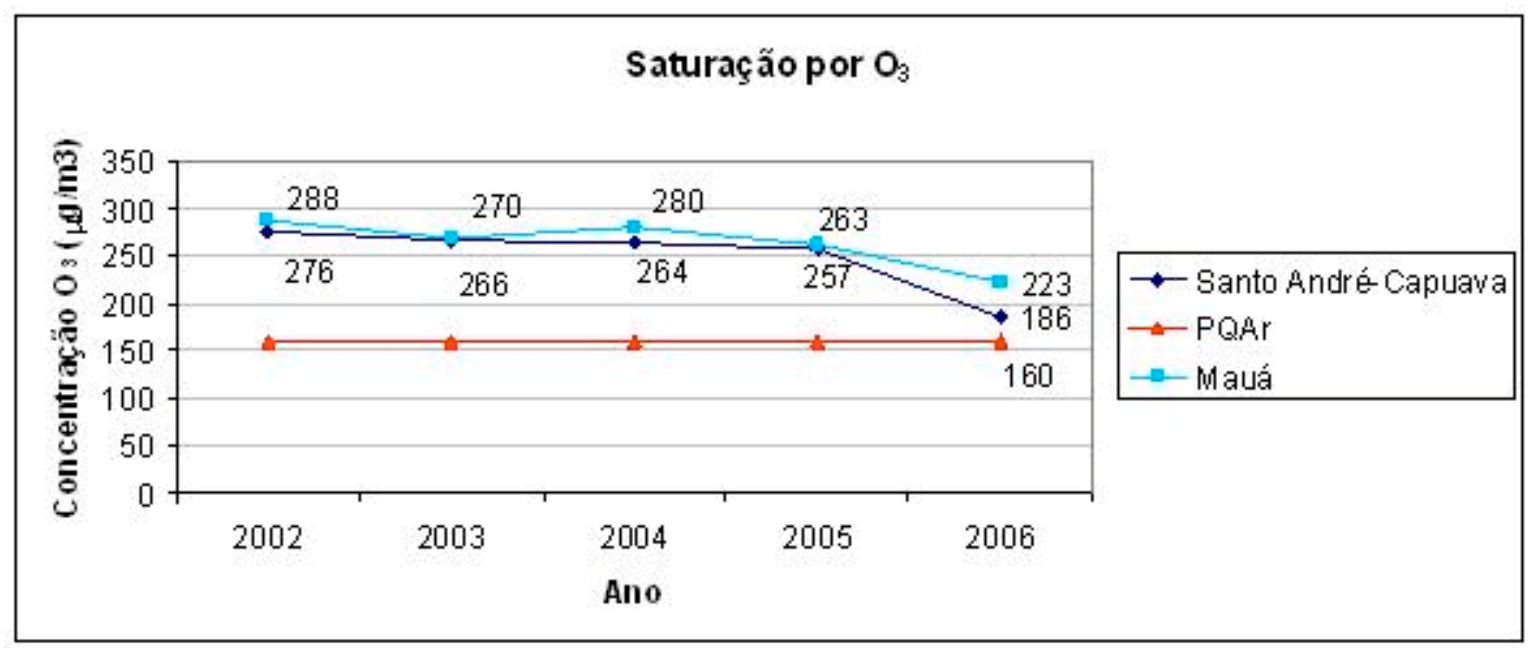

Figura 5.4- Evolução da condição das bacias aéreas do ABC para ozônio troposférico Fonte: CETESB 2007 e elaboração própria

\section{a) Caracterização do Empreendimento}

A unidade de cogeração de energia elétrica a gás natural, prevista para ser implantada no interior da unidade industrial da PQU- Petroquímica União, no distrito industrial dos Municípios de Santo André e Mauá, Pólo Petroquímico de Capuava, região metropolitana de São Paulo, para geração de 240MW de energia elétrica e até 500t/h de vapor teve seu pedido de licenciamento ambiental solicitado e analisado em 2000, para a razão social Capuava Energy Ltda, sendo emitida a licença prévia para a empresa

O Estudo e Impacto Ambiental (EIA) e Relatório de Impacto Ambiental (RIMA) foram submetidos em dezembro de 2000, tendo sido realizadas complementações em 2001 (Resposta Ofício CPRN/DAIA).

A empresa teve sua licença de instalação emitida em 14 de fevereiro de 2003 e solicitou alteração de razão social de Capuava Energy para Capuava Cogeração, solicitando, em 2007 a prorrogação da licença de instalação em virtude da do empreendimento ainda não ter se instalado no pólo petroquímico de Capuava em Santo André.

No caso particular da Capuava Cogeração (Antiga Capuava Energy), as características descritas no EIA e aprovadas pelo o Sistema de Meio Ambiente consideram a cogeração na 
PQU- Petroquímica União, aproveitando as altas temperaturas dos gases de exaustão da turbina a gás em caldeira de recuperação para geração de vapor de processo.

O combustível a ser utilizado será o gás natural e gás de processo produzido pela PQU, sendo que para o sistema de cogeração, os equipamentos e dados técnicos são: 2 (duas) turbinas a gás com capacidade ISO $\left(15^{\circ} \mathrm{C}\right.$ e nível do mar) de $120 \mathrm{MW}$ cada; 2 (duas) caldeiras de recuperação de vapor com queima suplementar, de capacidade total de $250 \mathrm{t} / \mathrm{h}$ cada; 1 (uma) turbina de vapor de contrapressão com capacidade nominal de 10MW.

Como combustível utilizado no projeto, o estudo informa que será utilizado um mix de gás natural (800.000 a $1.300 .00 \mathrm{Nm}^{3} /$ dia) e Gás de Processo (9t/h). Não foi previsto inicialmente um cenário de falta de gás e os impactos da utilização de óleo combustível como alternativa, motivo pelo qual o estudo necessitou de complementações.

Ainda segundo dados do estudo seriam desligadas 5 das 6 caldeiras em operação da Petroquímica, mas uma delas permanecerá no local para garantir uma reserva de segurança, em carga mínima de $30 \mathrm{t} / \mathrm{h}$ de vapor (60t/h em operação a carga máxima) em caso de paralisação repentina da central de cogeração, evitando parada de emergência da PQU por falta de vapor.

O EIA da usina termelétrica Capuava Cogeração indica duas formas para redução das emissões de óxidos de nitrogênio $\left(\mathrm{NO}_{\mathrm{x}}\right)$ :

A) Técnicas de tratamento de gases: considerando três sistemas para alcançar redução de emissões:

- Redução Catalítica Seletiva (SCR) - considerado um sistema oneroso e que apresenta riscos no manuseio e armazenamento da amônia anidra (gasosa), substância utilizada no sistema SCR.

- Redução Não Catalítica Seletiva (SNCR) - utilizando como substâncias a amônia ou a uréia, considerado um sistema que atualmente ainda não apresenta condições de ser implantado por ser uma técnica que se encontra em estágio de desenvolvimento.

- Adsorção: técnica cuja eficiência só pode ser comprovada em plantas de pequena capacidade.

B) Controle do processo de combustão, considerando combustores do tipo seco de baixo teor de $\mathrm{NO}_{\mathrm{x}}$, também denominado DLN (Dry Low-NO $\mathrm{N}_{\mathrm{x}}$ ), e a injeção de água ou vapor: 
- Combustores tipo DLN: sua utilização foi descartada devido à utilização de um gás combustível que é obtido através de um mix Gás Natural/Gás de processo (PQU), o que pode determinar variações do número de Wobbe acima de $5 \%$, considerada excessiva para a sensibilidade dos sistemas DLN. É mencionada também a presença de concentrações de hidrogênio que poderiam prejudicar o desempenho do sistema DLN.

- Injeção de vapor, sistema adotado pela usina termelétrica Capuava Cogeração para a redução das emissões dos óxidos de nitrogênio. Este sistema é apresentado como capaz de atingir emissões tão baixas quanto a utilização do sistema DLN.

Devido a dificuldade de estabilização na utilização de Gás de Processo no sistema de cogeração, as tecnologias de DLN em queimadores não foi contemplada, utilizando-se assim a injeção de vapor como método de redução da formação de $\mathrm{NO}_{\mathrm{x}}$. Hoje a prática de utilização de vapor como técnica de redução de emissão de $\mathrm{NO}_{\mathrm{x}}$ não é mais recomendada, visto que as tecnologias de redução catalítica e não catalítica seletivas apresentam maior eficiência, sem a geração de amônia como subproduto.

Utilizando o gás natural como combustível, a alternativa Dry Low-NO $\mathrm{N}_{\mathrm{x}}$ proporciona uma potência líquida de 118,39 MW, com um consumo do gás natural da ordem de 25,461t/h. Por sua vez, a alternativa de injeção de água para redução de $\mathrm{NO}_{\mathrm{x}}$ possibilita uma potência líquida de 129,91 MW, com consumo do gás natural de 28,677 t/h. Por fim, a alternativa de Injeção de vapor permite alcançar uma potência líquida de $135 \mathrm{MW}$, com um consumo do gás natural da ordem de 27,647 t/h.

Verifica-se, portanto, que a adoção da alternativa de Injeção de vapor representa também um significativo aumento na potência líquida. Este aumento traz evidentes vantagens comerciais para o gerador, que pode produzir e comercializar mais $\mathrm{kWh}$. Por outro lado, este aumento também acarreta o consumo de um volume maior de gás, de 25,4 t/h para $27,6 \mathrm{t} / \mathrm{h}$ para cada turbina.

Em termos quantitativos, o projeto da usina termelétrica Capuava Cogeração prevê a Injeção de 90 t/h de vapor nas turbinas à gás para controle das emissões de NOx. Esta quantidade de vapor representa um acréscimo no consumo de água. 


\section{b) Características das emissões}

De acordo com as informações disponíveis e apresentadas quando do licenciamento, as emissões são mostradas considerando as características de operação das caldeiras da PQU antes e depois da conversão para gás e as alterações propostas pela implantação da central de cogeração.

Contemplados por tipo de combustível (BF 9001, BF 9002, BF 9003, BF 9005, BF 1900) e características dos equipamentos, as emissões globais conferidas pelo sistema de cogeração proposto são mostrados na tabela 5.1, e refletem as condições de emissão antes e depois das alterações propostas no estudo.

Tabela 5.1- Características das fontes emissoras de poluentes atmosféricos

\begin{tabular}{|c|c|c|c|c|c|}
\hline & \multicolumn{4}{|c|}{ taxas cle emissão (kg h) } \\
\hline & & S02 & $110 x$ & $\operatorname{cov}$ & MP10 \\
\hline PQU & antes du corrver: & 703,49 & 226,57 & 2,14 & 31,01 \\
\hline PQU & após conter?o (GH) & 0,49 & 144,35 & 0,74 & 4,72 \\
\hline Grpurv Cogeracīo & Central de coqeração & 1.03 & 115,2 & 1.85 & 3,96 \\
\hline (em issốes esperadas) & Caldeira existente (60th) & 0,07 & 20,87 & 0,11 & 0,68 \\
\hline & Totrl & 1,1 & 136,07 & 1,96 & 4,64 \\
\hline Gopurv Cogerafio & Central de coqeraçẫo & 1,03 & 118,8 & 2,33 & 12,24 \\
\hline (em issôes garantidas) & Caldeira existente (60th) & 0,07 & 20,87 & 0,11 & 0,68 \\
\hline & Totrl & 1,1 & 139,67 & $\mathbf{2 , 4 4}$ & 12,92 \\
\hline
\end{tabular}

Com bustivel das caldeiras antes da conversầo: Óleo Combustivel

Emissôes Esperadas: Átualmente obtidas

Emissốes Garantidas: Dados fornecidos pelo fabricante (turbinas e caldeira de recuperaçẫo)

Fonte: EIA Capuava Cogeração (Capuava Eenergy), 2000

\section{c) Cálculos para geração de créditos}

Do processo da Capuava Energy, as emissões de precursores de ozônio estão concentradas primordialmente no processo da própria petroquímica e do sistema de cogeração da cogeradora, sendo a caldeira de geração de vapor as emissões de óxidos de nitrogênio e orgânico voláteis (fonte fixa).

Para o cálculo das emissões, conforme preconiza a legislação, são assumidos os dados do EIA e:

- Operação do sistema: 24h/dia, 365dia/ano;

- Fatores de emissão para combustão de gás em turbina estacionária -AP42 com injeção de vapor.

*Taxa de Emissão de poluentes: t/ano 
Tabela 5.2- Geração de créditos de reduções de poluentes atmosféricos na UTE

\begin{tabular}{|c|c|c|c|c|}
\hline & & $\mathrm{NOx}$ & $\mathrm{COV}$ & \multirow{9}{*}{ 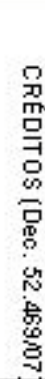 } \\
\hline PQU (1999) & antes da conversẫo (GN) & 1984,75 & 18,75 & \\
\hline PQU & após conversāo (GN) & 1264,51 & 6,48 & \\
\hline \multirow{3}{*}{$\begin{array}{l}\text { Capu ava Coger açāo } \\
\text { (emissổes esperadas) }\end{array}$} & \multirow{3}{*}{$\begin{array}{l}\text { Central de cogeração } \\
\text { Caldeira existente }(60 / t / h) \\
\text { Total }\end{array}$} & 1009,15 & 16,21 & \\
\hline & & 182,82 & 0,96 & \\
\hline & & 1191,97 & 17,17 & \\
\hline \multirow{3}{*}{$\begin{array}{l}\text { Capuava Coger açāo } \\
\text { (emissốes garantidas) }\end{array}$} & \multirow{3}{*}{$\begin{array}{l}\text { Central de cogeração } \\
\text { Caldeira existente }(60 / t / h) \\
\text { Total }\end{array}$} & 1040,69 & 20,41 & \\
\hline & & 182.82 & 096 & \\
\hline & & 1223,51 & 21,37 & \\
\hline \multirow{2}{*}{$\begin{array}{l}\text { CREDITOS } \\
\text { (Decreto } 50.753 / 06) \\
\end{array}$} & emissỗes esperadas & 72,53 & $-10,69$ & - \\
\hline & emissões garantidas & 41,00 & $-14,89$ & - \\
\hline
\end{tabular}

Fonte: Elaboração própria

Assim, para o cálculo das reduções de emissões dos precursores de ozônio não foram consideradas reduções de emissões ocorridas em 1999 quando da alteração do tipo de combustível. Também considerou-se a redução das emissões provenientes da troca dos equipamentos (esperadas) e contemplando as margens de segurança fornecidas pelo fabricante (garantidas), para injeção de vapor na câmara de combustão do equipamento como medida de redução de $\mathrm{NO}_{\mathrm{x}}$.

Da aplicação do Decreto Estadual n $50.753 / 06$ as alterações sugeridas no EIA gerariam créditos de pelo menos 41t/ano de $\mathrm{NO}_{\mathrm{x}}$ e necessidade de redução de 14,89t/ano de COVs, que poderia se dar pela adoção de outras tecnologias, na combustão do gás natural ou na adoção de equipamentos de controle pós queima de forma a não prejudicar a combustão do combustível e formação de voláteis.

Segundo a Novíssima redação conferida pelo Decreto Estadual n52.469/07, a implantação da atividade deverá buscar as reduções ou créditos no momento em que a bacia aérea se tornar severamente saturada, não sendo necessária a compensação das emissões nem geração dos créditos mencionados acima. Entretanto, o licenciamento se dará pela adoção da melhor tecnologia prática disponível, conforme apresentada no Estudo de Impacto Ambiental para análise e emissão das Licenças Prévias e de Instalação. 
Cabe agora ao empreendimento, quando de sua instalação solicitar créditos referentes às reduções que obterá com a mudança da tecnologia de injeção de vapor para DLN sendo esta alteração interessante sob o ponto de vista econômico-financeiro.

\section{2- Usina de Açúcar e Álcool}

Usinas de Açúcar e Álcool são unidades industriais que, através do processamento de cana de açúcar produzem açúcar através do processo de cristalização e álcool através da destilação.

O fluxo de processo a seguir procura dar uma idéia das principais etapas na fabricação do álcool, contemplando os principais equipamentos para fermentação e elevação do teor de álcool até atingimento do grau necessário. (figura 5.4)

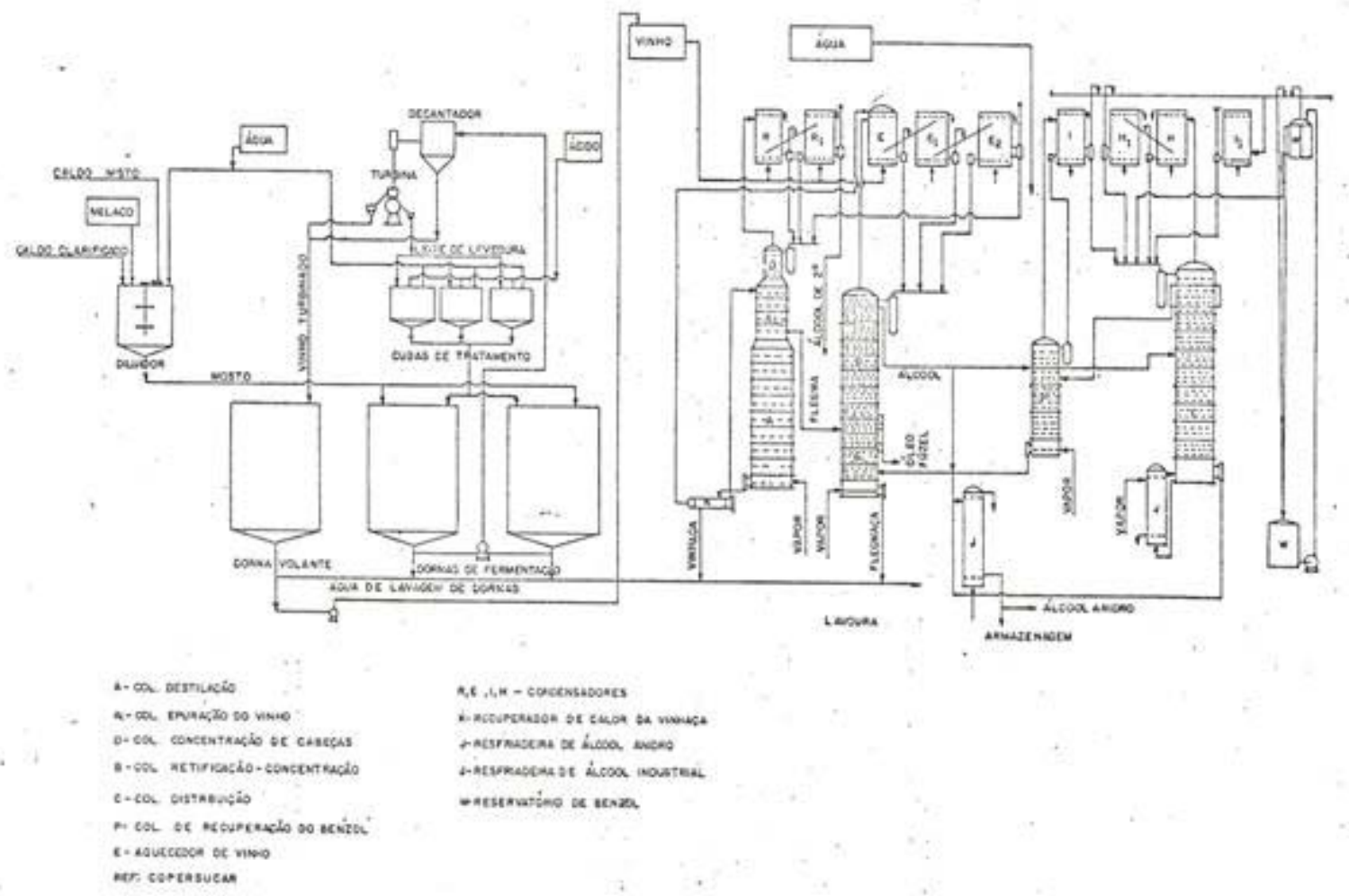

Figura 5.5- Fluxograma simplificado de uma usina de açúcar e álcool Fonte: CETESB apud COPERSUCAR (1985)

A cogeração de energia em usinas de açúcar e álcool, geração simultânea de mais de uma forma de energia, geralmente mecânica e elétrica, através de um combustível (energia térmica) é uma prática que visa aumentar a eficiência global da instalação e também a 
redução do consumo de energia elétrica da planta, com possível venda de excedente à rede, segundo a Agência Reguladora de Energia Elétrica pela Resoluções Normativas ANEEL $\mathrm{n}^{\circ} 112$ de 18 de maio de 1999 e $\mathrm{n}^{\circ} 235$ de 14 de novembro de 2006.

Além do ganho para a indústria, o sistema interligado ganha maior alívio uma vez que tratase de geração descentralizada e complementar à geração hidroelétrica, primordial na nossa matriz de geração elétrica, na medida em que o período de safra da cana-de-açúcar corresponde ao período de restrição hídrica (estiagem).

Para a utilização do excedente de bagaço de cana na própria usina com finalidade de cogeração de energia elétrica, a caldeira é o equipamento principal a ser estudado pois deve garantir o suprimento de vapor levemente superaquecido, à pressão de 1,5 a $2,5 \mathrm{kgf} / \mathrm{cm}^{2}$, numa temperatura de 140 a $160^{\circ} \mathrm{C}$ gerando de 350 a $600 \mathrm{~kg}$ de vapor por tonelada de cana processada. A disponibilidade hídrica, assim como no caso das termoelétricas, é fator de viabilidade nesta expansão.

\subsection{1- Usina Santo Antônio}

O empreendimento está localizado no noroeste do Estado de São Paulo, na Região Administrativa de Ribeirão Preto que ocupa 3,7\% do território estadual e apresenta uma das maiores densidades demográficas do Estado (117 hab/ $\left.\mathrm{Km}^{2}\right)$, sendo que o município de Ribeirão Preto a densidade é superior a $800 \mathrm{hab} / \mathrm{km}^{2}$.

A economia da região apóia-se no setor agropecuário, com destaque para a plantação de soja, café, amendoim, milho e laranja e na agroindústria sucroalcooleira que representa mais de $70 \%$ do valor total da produção agrícola da região. 


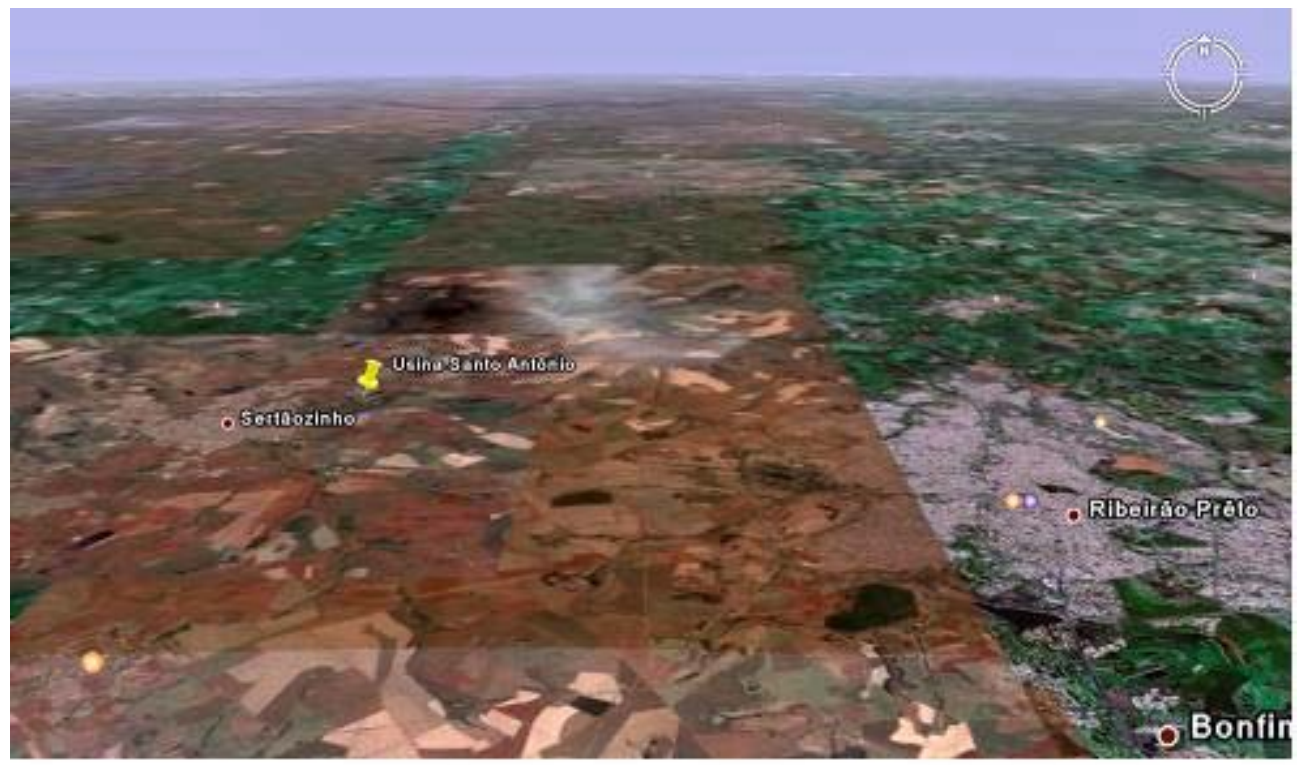

Figura 5.6- Reprodução de imagem animada da região de Sertãozinho e Ribeirão Preto

Fonte: GOOGLE (2007)

Pela figura 5.5 nota-se que a densidade demográfica de Ribeirão Preto é comparativamente mais alta que no município de Sertãozinho. Por seu turno, nas proximidades da usina de açúcar e álcool Santo Antônio é quase inexistente a pressão antrópica, sendo que na região de Ribeirão Preto há licenciadas cerca de 100 empreendimentos das mais variadas atividades, sendo 44 de pequeno porte ou microempresas licenciados, caracterizando-se por seu uma região de vocação rural e agroindustrial.

Segundo os critérios atualmente vigentes para classificação das sub-regiões, a região de Ribeirão Preto encontra-se classificada como Em Vias de Saturação, não havendo grau de severidade para estes casos $\left(152 \mu \mathrm{g} / \mathrm{m}^{3}\right)$. A figura 5.6 apresenta a comparação do padrão de qualidade do ar obtido em 2006 em comparação com o recomendado pela legislação. 


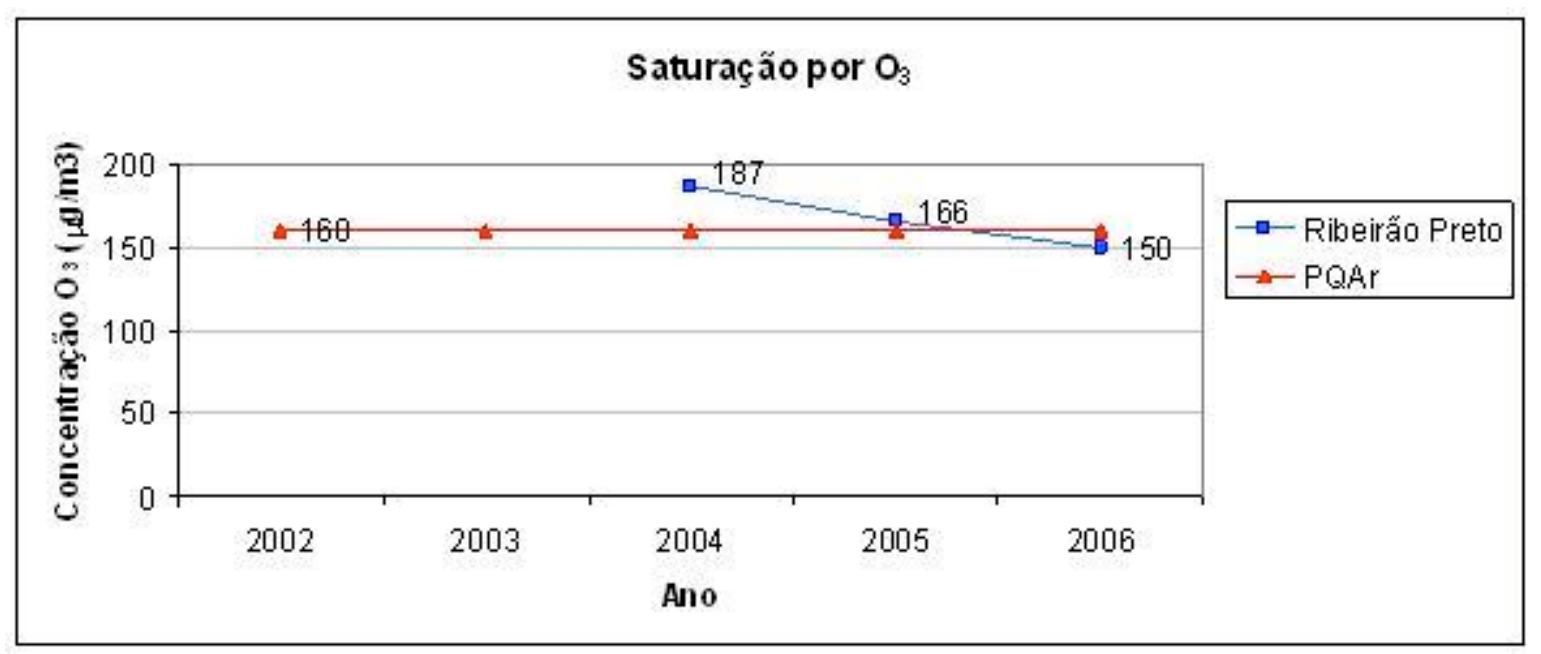

Figura 5.7- Evolução da condição das bacias aéreas de Ribeirão Preto para ozônio troposférico

Fonte: CETESB 2007 e elaboração própria

\section{a) Caracterização do Empreendimento}

A unidade de cogeração de energia elétrica através da queima do bagaço de cana-de-açúcar na Usina Santo Antônio, no município de Sertãozinho, região de Ribeirão Preto, para geração média anual de $83.600 \mathrm{MW}$ de energia elétrica, $405.000 \mathrm{tv} / \mathrm{h}$ a $21 \mathrm{Kgf} / \mathrm{cm}^{2}$ e $536.000 \mathrm{tv} / \mathrm{h}$ a $62 \mathrm{Kgf} / \mathrm{cm}$ teve seu pedido de licenciamento ambiental solicitado e analisado através da dispensa de licenciamento ambiental para os equipamentos já licenciados na Usina (caldeira) em 2001, para a razão social Bioenergia Cogeradora Ltda, sendo emitida a licença prévia para a empresa.

Cumprida as exigências técnicas para instalação de turbina e demais equipamentos, em 2002 foi emitida a licença de Instalação e em 2004 e 2005 as licenças de Operação a Título Precário, devida a necessidade de comprovações de eficiência dos equipamentos de controle de poluentes atmosféricos.

Assim, em 03/05/2006 o empreendimento recebeu Licença de Operação para produção média anual de $83.600 \mathrm{MW}$ de energia elétrica, $405.000 \mathrm{tv} / \mathrm{h}$ a $21 \mathrm{Kgf} / \mathrm{cm}^{2}$ e $536.000 \mathrm{tv} / \mathrm{h} \mathrm{a}$ $62 \mathrm{Kgf} / \mathrm{cm}^{2}$. 


\section{b) Características das emissões}

Da fabricação do álcool, as emissões de precursores de ozônio estão concentradas primordialmente após o processo de fabricação e também no parque de tancagem da usina, para compostos orgânicos voláteis e na caldeira de geração de vapor para óxidos de nitrogênio. A cogeração de energia, usuária de vapor da usina não contribui substancialmente com a emissão de poluentes atmosféricos no âmbito de análise deste estudo.

As emissões de COVs e de NOx serão analisadas em separado sendo que, para efeito da aplicação da metodologia aplicada pelo órgão de meio ambiente, podem ser divididas em:

- Emissões fugitivas: dos equipamentos (válvulas, torres de resfriamento, bombas e compressores).

- Emissões de fonte área ou aberta: Sistema de separação água-óleo oriundo do parque de tancagem.

- Emissões evaporativas: parque de tancagem.

- Emissões de fontes fixas: caldeira.

As principais características do processo industrial e dos equipamentos da Usina Santo Antônio, para emissões mais significativas de COVs, segundo visita ocorrida em dezembro de 2007 são as seguintes, considerando fatores de emissão do AP-42, metodologia adotada pela CETESB e assumindo-se alguns valores padrões de processo são:

\section{i) Emissões Fugitivas}

Considerou-se álcool anidro e hidratado como Líquido Leve, operação da planta de $4320 \mathrm{~h} /$ ano e o fator de conversão de $0,0004536 \mathrm{t} / \mathrm{lb}$.

Tabela 5.3- Emissões por fontes fugitivas da UAA Santo Antônio

\begin{tabular}{|c|c|c|c|c|c|}
\hline Dispositivos & $\begin{array}{l}\text { Qde. } \\
\text { n }^{\circ}\end{array}$ & $\begin{array}{l}\text { Fator de Emissão } \\
\text { (COV) kgh fonte }\end{array}$ & $\begin{array}{c}\text { Operação } \\
\text { h/ano }\end{array}$ & $\begin{array}{c}\text { Emissão COV } \\
\text { kglano }\end{array}$ & $\begin{array}{c}\text { Emissảo CoV } \\
\text { t/ano }\end{array}$ \\
\hline válvulas & 75 & 0,0109 & 8760 & 7161,30 & 7,16 \\
\hline bombas & 8 & 0,114 & 8760 & 7989,12 & 7,99 \\
\hline válvulas de alívio & 16 & 0,16 & 8760 & 22425,60 & 22,43 \\
\hline conexốes & 40 & 0,00025 & 8760 & 87,60 & 0,09 \\
\hline drenos & 55 & 0,0023 & 8760 & 1108,14 & 1,11 \\
\hline & \multicolumn{3}{|r|}{ Totnl } & 38771,76 & 38,77 \\
\hline
\end{tabular}

Fonte: Elaboração própria 


\section{ii) Emissões Evaporativas}

Consideraram-se no parque de tancagem as seguintes características dos tanques, operação de estocagem e movimentação, para simulação das emissões através do programa TANKs 4.09d:

- Características dos tanques:

- Número de tanques: 4

- Tipo de teto: teto interno flutuante

- Dimensões / volume:

- $\quad$ - tq 1: 75ft, 2.700,00gal.

- $\quad$ - tq 2: $75 \mathrm{ft}, 2.700,00 \mathrm{gal}$.

- $\quad$ - tq 3: 75ft, 2.700,00gal.

- $\quad$ - tq 4: $75 \mathrm{ft}, 2.700,00 \mathrm{gal}$.

- Número de giros por ano: 10 com teto auto-suportado

- Características da pintura dos tanques:

- Condições do costado interno: levemente oxidado

- Cor/tonalidade do costado: branco

- Condições do costado: boa

- Cor/tonalidade do teto: branco

- Condições do teto: boa

- Sistema de selagem:

- Tipo de selo primário: sapata mecânica

- Tipo de selo secundário: nenhum

- Características da cobertura:

- Categoria dos acessórios: típica

- Tipo da cobertura: soldada

- Características dos produtos estocados:

- Componentes: Álcool etílico (etanol)

- Classificação: líquido orgânico

- Tipo de estocagem: cativo

- Características da movimentação:

- Distribuição: similar em todos os meses do ano

- fator de conversão de $0,0004536 \mathrm{t} / \mathrm{lb}$

Tabela 5.4- Emissões por fontes evaporativas da UAA Santo Antônio

\begin{tabular}{|c|c|c|c|c|c|}
\hline Dispositivos & $\begin{array}{l}\text { Qde. } \\
n^{\circ}\end{array}$ & Tipo de tancpue & $\begin{array}{c}\text { Prochito } \\
\text { Estocado }\end{array}$ & $\begin{array}{l}\text { Emissão COV } \\
\text { (indiv) t/ano }\end{array}$ & $\begin{array}{l}\text { Emissão COV } \\
\text { (todlos) t/ano }\end{array}$ \\
\hline Tanques (1 a 8) & 8 & aéreo chacia de conteç̂̃o & etanol & 1,2592 & 10,0736 \\
\hline \multicolumn{4}{|c|}{ GÉDITOS (Dexreto n'50.753106) } & totrl & 10,0736 \\
\hline
\end{tabular}

Fonte: Elaboração própria

\section{iii) Emissões por fonte fixa}

Consideraram-se as características das caldeiras atualmente utilizadas na UAA e o consumo de bagaço de cana, antes e depois da expansão da produção de vapor da usina. 
- Caldeira 1 - $63 \mathrm{Kgf} / \mathrm{cm}^{2}$ - Consumo de Bagaço - 80 ton/h

- Caldeira 2 - $21 \mathrm{Kgf} / \mathrm{cm}^{2}$ - Consumo de Bagaço - 40 ton $/ \mathrm{h}$

- Caldeiras 4 e 5 - $21 \mathrm{Kgf} / \mathrm{cm}^{2}$ - Consumo de Bagaço - 40 ton $/ \mathrm{h}$

- Consumo Total de Bagaço - 120 ton/h

- - fator de conversão de $0,0004536 \mathrm{t} / \mathrm{lb}$

- - taxa de emissão $\mathrm{NO}_{\mathrm{x}}=1,2 \mathrm{lb} /$ ton bagaço ( $50 \%$ umidade)

- - taxa de emissão $\mathrm{COV}=0,001 \mathrm{lb} /$ ton (em termos de compostos orgânicos policíclicos)

- Considerou-se Operação do Sistema: 24h dia 365dia.

Quando da instalação da caldeira 1 houve a desativação da caldeira 2 para geração de vapor de processo a uma pressão mais elevada.

Tabela 5.5- Emissões de NOx e COV por fontes fixas da UAA Santo Antônio

\begin{tabular}{|c|c|c|c|c|c|c|c|c|}
\hline Di:positivo: & $\begin{array}{l}\text { Qde. } \\
n^{\circ}\end{array}$ & $\begin{array}{c}\text { Cons umo bagaço } \\
\text { th }\end{array}$ & $\begin{array}{l}\text { Fator de En lisaso } \\
\text { (110:) lbititonte }\end{array}$ & $\begin{array}{l}\text { Fa tor de EnI : : so } \\
\text { (Oov) lb ittonte }\end{array}$ & $\begin{array}{c}\text { Fator de converiaso } \\
\text { tib }\end{array}$ & $\begin{array}{l}\text { Operaça } \\
\text { hatano }\end{array}$ & $\begin{array}{c}\text { Enl: tå o } 110 \mathrm{x} \\
\text { tano }\end{array}$ & $\begin{array}{c}\text { En lis } 3000 \mathrm{OV} \\
\text { tano }\end{array}$ \\
\hline 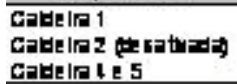 & $\begin{array}{l}1 \\
1 \\
2\end{array}$ & $\begin{array}{l}\text { 晶 } \\
\text { 吅 }\end{array}$ & $\begin{array}{l}12 \\
12 \\
12\end{array}$ & 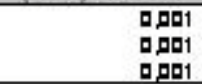 & 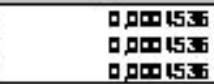 & $\begin{array}{l}8160 \\
8160 \\
8160\end{array}$ & $\begin{array}{l}381,5 \\
190,1 \\
3815\end{array}$ & $\begin{array}{l}0,3 \\
0,2 \\
0,3\end{array}$ \\
\hline & & & & & & Tatal & 9조5 & 0,8 \\
\hline
\end{tabular}

Fonte: Elaboração própria

\section{c) Cálculos para geração de créditos}

Para o cálculo das reduções de emissões dos precursores de ozônio foram consideradas reduções de emissões ocorridas com a instalação da caldeira 1 em 2000.

Considerando-se que as emissões das caldeiras 4 e 5 se mantiveram, o aporte de poluentes atmosféricos é dado pela diferença entre o emitido pela caldeira 1 e a caldeira 2 (desativada).

Como as alterações propostas não refletiram em aumento da produção de açúcar e álcool, as contribuições de emissão de COV pelas fontes fugitivas e evaporativas podem ser consideradas constantes.

Tabela 5.6- Geração de créditos de reduções de poluentes atmosféricos na UAA Santo Antônio

\begin{tabular}{lccrrr}
\hline \multicolumn{1}{c}{ Dispositivos } & $\begin{array}{c}\text { Qde. } \\
\mathbf{n}^{\circ}\end{array}$ & $\begin{array}{c}\text { Consumo bagaço } \\
\text { th }\end{array}$ & $\begin{array}{c}\text { Emissäo NOx } \\
\text { t/ano }\end{array}$ & $\begin{array}{c}\text { Emissäo COV } \\
\text { t/ano }\end{array}$ \\
\hline Caldeira 1 & 1 & 80 & 381,5 & 0,32 \\
Caldeira 2 (desativada) & 1 & 40 & 190,7 & 0,16 \\
\hline CRÉDTOS (Decreto n"50.753/06) & & $-190,7$ & $-0,16$ \\
\hline
\end{tabular}

Fonte: Elaboração própria 
Da aplicação do Decreto Estadual n ${ }^{\circ} 50.753 / 06$ as alterações promovidas na planta gerariam demanda por créditos de pelo menos 190,7t/ano de $\mathrm{NO}_{\mathrm{x}}$ e de 0,16t/ano de COV, que poderia se dar pelo aprimoramento das tecnologias de controle de emissão de poluentes. Vale mencionar que as alterações se deram em 2000, período em que não vigorava este decreto.

Segundo a novíssima redação conferida pelo Decreto Estadual n $52.469 / 07$, a retroatividade da geração dos créditos é prevista para pedidos de licenciamento ou alterações solicitadas após 28 de abril de 2003, não se aplicando novamente ao caso.

Entretanto, a nova redação prevê geração de créditos por medidas que, comprovadamente, resultem na redução de emissão de poluentes para a atmosfera, podendo a empresa buscar tais medidas na mecanização da fase agrícola do processamento da cana de açúcar, com redução de $\mathrm{MP}, \mathrm{NO}_{\mathrm{x}}$ e $\mathrm{COV}$, gerando créditos que podem ser comercializado dentro da bacia, inclusive com municípios vizinhos, como no caso de Ribeirão Preto.

As flexibilizações conferidas pela novíssima redação possibilitam maiores oportunidades de negócios entre atividades diferentes, o que, para a qualidade geral da bacia é indistinda, desde que ocorram reduções de emissões de remanescentes de poluentes emitidos à atmosfera. 


\section{6- CONCLUSÕES}

As recentes alterações na legislação mostram que o tema está em constante discussão pelos vários atores e contemplam, cada vez mais os anseio destes. A legislação trás reflexos nas várias esferas: Estado, Setor produtivo e Sociedade. A busca do consenso no sentido da proposição de soluções vantajosas a todas as partes motiva a revisão periódica dos procedimentos de licenciamento que, procuram ser inovadores e arrojados neste sentido, dando ao Estado o caráter vanguardista de propor mecanismos complexos mas que visam o atendimento de sua missão: proteger o meio ambiente sem impedir o crescimento econômico.

É inevitável que ações de proteção da qualidade do ar sejam tomadas no sentido de se evitar a saturação das bacias e o atingimento de um grau severo nas mesmas, o que trás graves conseqüencias à saude da população, aos materiais, entre outros.

O processo de aprovação e revisão da legislação é natural e deverá ter curso por mais tempo. Como referência de processos de utilização de gestão ambiental através de comércio de emissões há o Estado da Califórnia que, desde 1940 vem adotando medidas no sentido de reduzir seus níveis críticos de poluição do ar. Medidas de comando e controle, incentivos a adoção de melhores tecnologias, uso de modelos de dispersão, inventário e comércio de emissões foram os caminhos percorridos que se seguiram na Califórnia.

A diferença principal entre o programa RECLAIM - Regional Clean Air Incentives Market, adotado na Califórnia e o modelo de São Paulo está na concepção de linha de base adotada com base nas máximas emissões das indústrias, ocorrida entre 1989-1992 e metas de reduções constantes anuais entre 1994 e 2003 naquele Estado.

No caso Paulista, por não haver um inventário consolidado optou-se pela adoção de linha de corte de emissão e metas de redução sem prazo definido. Na última alteração ocorrida em 2007 a legislação se aproximou do modelo adotado pela Califórnia, com prazo para elaboração do inventário de emissões.

A legislação baseada em comércio de emissões, o chamado "cap and trade emission market" também inspirou iniciativas de implantação pela EPA em âmbito federal, com a 
elaboração do $\mathrm{SO}_{2}$ Allowance Trading, $\mathrm{NO}_{\mathrm{x}}$ Budget Program de New Jersey e o $\mathrm{NO}_{\mathrm{x}} \mathrm{SIP}$ Call na Pennsylvania, todos com formato similar ao adotado na Califórnia. Há também a Ley de Bonos de Descontaminación, adotada na bacia aérea de Santiago pelo Governo do Chile que ainda não entrou em vigor já tendo passada por 2 revisões do CONSEMA local nos últimos 8 anos.

Assim como ocorrido na Califórnia, onde as bases para adoção do RECLAIM foram discutidas por 3 anos, São Paulo também segue o mesmo caminho.

As emissões apuradas nos licenciamentos ambientais no Estado de São Paulo poderão ser utilizadas no Mercado Paulistas de Emissões Atmosféricas mas primeiro dever-se-ia haver incentivos maciço à geração do créditos para os poluente específicos, como forma de promover o embrião deste mercado.

$\mathrm{O}$ instrumento de compensação ambiental, com a adoção de fundos à semelhança dos Superfound americanos, prevendo recursos a serem usados na remediação de áreas contaminadas têm mostrado não ser uma alternativa eficaz na melhoria da qualidade do meio.

Essa proposição de adoção de um fundo que receberia recursos oriundos do processo de licenciamento de empresas com processo que contribuíssem com a deterioração da qualidade do ar em bacias aéreas saturadas e em vias de saturação, proposto pela Secretaria de Desenvolvimento do Estado motivou novamente a flexibilização dos prazos e maior publicidade do programa de redução de emissões atmosféricas e do mecanismo de compensação através da geração, utilização de créditos pelo abatimento de poluentes regulamentados (art. 42A do Decreto Estadual $\mathrm{n}^{\mathrm{0}} 52.469 / 07$ ) e procedimentos para o licenciamento, uma vez que entende-se ser um mecanismo mais efetivo no enfrentamento da questão da saturação das bacias aéreas no Estado de São Paulo.

O governo do Estado de São Paulo mostra que, embora a construção do consenso seja cara e demorada, está procurando evoluir nas questões ambientais de modelos repressores de comando-controle para formas de gestão do meio, através de iniciativas novas e arrojadas e que, neste caso favorece não só ao meio ambiente, quanto ao desenvolvimento de novos 
mercados, conforme colocado anteriormente, por exemplo, incentivo à novas tecnologias menos poluentes e equipamentos de controle mais eficientes que, possibilitem a geração de créditos e posterior comércio pelo setor industrial ou organismos que possam atuar nesta área.

Exemplos de possibilidade de alteração da trajetória da curva de degradação do meio está na substituição de equipamentos, como no caso da Capuava Cogeração, podendo gerar menos 41t/ano de $\mathrm{NO}_{\mathrm{x}}$ e necessidade de redução de 14,89t/ano de COVs ou mesmo no caso da Usina São Francisco que geraria demanda de 190,7t/ano de $\mathrm{NO}_{\mathrm{x}}$ e de 0,16t/ano de COV, investindo em outras plantas, alterando sua fase agrícola ou recorrendo ao mercado paulista de emissões atmosféricas.

A melhoria constante da qualidade dos combustíveis e adoção do Programa de Inspeção Veicular (PIV) é uma medida consagrada internacionalmente e que trás benefícios para a melhoria da qualidade do ar nas regiões metropolitanas. Este programa poderia ser incluído como fomento à geração de créditos e abatimento de tarifas e impostos dentro do próprio Estado, como por exemplo, abatimento no IPVA (Imposto sobre Propriedade de Veículos Automotores).

Cabe agora, por parte do Estado, a consolidação do inventário de fontes para elaboração da curva $\mathrm{ABC}$ utilizada como linha de corte para os empreendimentos existentes e, divulgação das novas bacias aéreas para definição de empreendimentos novos que necessitarão obter créditos para viabilizar seu licenciamento em áreas saturadas ou em vias de saturação.

Uma bolsa de comercialização de créditos também deverá ser instituída e o amadurecimento da conscientização dos atores deste novo mercado, no sentido de utilizarse desta ferramenta desburocratizada e de baixo custo condições de sucesso para o desenvolvimento de mais esta atividade econômica.

A Bolsa Mercantil e de Futuros (BMF) já se antecipou e publicou em seu balanço este projeto, antevendo tratar-se de um mercado de potencial para atrair investidores. 
No futuro a definição de índices que efetivamente representem condições ambientais e de saúde pública, que sejam claros e possíveis de utilização em planejamento urbano e em ações na saúde pública são importantes para orientação e conhecimento dos órgãos responsáveis, garantia do bem-estar público e manutenção da qualidade do meio. 


\section{7- REFERÊNCIAS BIBLIOGRÁFICAS}

ALVARES Jr, O. M., OSSES, M., NIKKILA, N., LENTS, J., Davis, N.: Vehicle activity and on-road emissions data collection for the application of the International Vehicle Emissions Model (IVE) in the Sao Paulo Metropolitan Region, São Paulo. 2006. Disponível em:<http://www.issrc.org/ive>. Acessado em 28 abr. 2007.

ALVARES Jr, O. M.: Veículos à álcool e o meio ambiente. Mensagem recebida por fabiof@cetesbnet.sp.gov.br em 10 set 2007 (informação pessoal).

ARB (California Air Resourses Board) Disponível em: <http://www.arb.ca.gov/homepage.htm>. Acessado em 22 dez. 2007.

ASSUNÇÃO, J. V.; PESQUERO, C. R: Qualidade do Ar. São Paulo, 2006. 29p Curso de Saúde Ambiental da Faculdade de Saúde Pública da USP (apostila).

BRASSEUR, G. P., ORLANDO, J. J., TYNDALL, G. S.: Atmospheric chemistry and global change - a textbook prepared by scientists at the National Center for Atmospheric Research, Boulder, Colorado, and other colleagues. Oxford University Press, 1999. 654p. (ISBN 0-19-510521-4).

CEPAL (Comisión Ecomómica para América Latina y el Caribe) e PNUMA (Programa das Nações Unidas para Meio Ambiente): Aspectos Econômicos de la Politica de control y fiscalizacion de fuentes fijas - Elementos para la discussión. In: Seminário Politicas para el control y fiscalización de la contaminación de los sectores productivos y energético, realizado em Santiago, entre 5 e 7 de dezembro de 1990. Chile: CEPAL/PNUMA 34p. Ref. LC/R. 982 (Sem. 61/4), 1991.

CETESB (Companhia de Tecnologia e Saneamento Ambiental): Nota sobre Tecnologia de controle de Fabricação de Açúcar e Álcool - Dezembro 1985. NT10 DCON 32p.

CETESB (Companhia de Tecnologia e Saneamento Ambiental): Tecnologia de controle da poluição do ar para material particulado, gases, vapores e odores e 
verificação de sistemas. São Paulo, 2003. 84p (Apostila Cursos e Treinamentos Práticos Especializados da CETESB).

CETESBNET - Intranet da Companhia de Tecnologia de Saneamento Ambiental (CETESB). Notícia exibida em 16 abr 2005 (informação pessoal).

CETESB (Companhia de Tecnologia e Saneamento Ambiental): Manual para aplicação do Decreto $\mathbf{n}^{\circ}$ 50.753/06, São Paulo, 2006. Versão 21.11.06, 36p. Disponível em: < http://www.cetesb.sp.gov.br/licenciamentoo/index2.asp >. Acessado em: 03 jan. 2008.

CETESB (Companhia de Tecnologia e Saneamento Ambiental): Relatório de Qualidade do Ar no Estado de São Paulo 2006, São Paulo, 2007a. 167p (Série Relatórios / Secretaria de Estado do Meio Ambiente, ISSN 0103-4103).

CETESB (Companhia de Tecnologia e Saneamento Ambiental): Estimativa de emissões de poluentes atmosféricos. São Paulo, 2007b. 274p. (Cursos e Treinamentos)

DIAS, A. D. M.: Avaliação de Tecnologias para redução de emissões de Óxidos de Nitrogênio em Usinas Termelétricas a Gás Natural, Trabalho de Conclusão de Curso apresentado à Escola Politécnica da Universidade de São Paulo para obtenção do grau de Bacharel em Engenharia, área de concentração Ambiental, São Paulo, 2007. 79p.

EPA (Environmental Protection Agency - EUA). Emissions Factors \& AP42. Fifth Edition, Volume I Chapter 1: External Combustion Sources. Disponível em <http://www.epa.gov/ttn/chief/ap42/>. Acessado em: 08 jan 2008.

EIA - Estudo de Impacto Ambiental da empresa Capuava Cogeração (Capuava Energy), apresentado ao Sistema de Meio Ambiente por ocasião da análise do seu licenciamento ambiental. São Paulo, 2000.

GOOGLE EARTH - Software free disponibilizado pela Google Corp. Servidor: <kh.google.com> Versão 4.2.0198.2451 (beta). Data da compilação: Sep 122007. Renderizador: DirectX 8. Sistema operacional: Microsoft Windows XP (Service Pack 
2). Driver de vídeo: 000010DE (00006.00014.00010.05673). Acessado em 21 dez 2007.

GOLDEMBERG, J.; SIRKIS, A.; TRIGUEIRO, A.; CAMARGO, A.; MINC, C.; VIOLA, E.; FELDMANN, F.; ALMEIDA, F.; GABEIRA, F.; CAPRA, F.; GIL, G.; CÂMARA, I.G.; CARVALHO, J.C.; VEIGA, J.E.; BOFF, L.; DUARTE, M.; NALINI, R.; BORN, R.H.; CRESPO, S.; BESSERMAN, S.; NOVAES, W. Meio Ambiente na Idade Mídia. In: Meio Ambiente no Século 21: 21 Especialistas falam da Questão Ambiental nas suas Áreas de Conhecimento. Coordenação de André Trigueiro. Rio de Janeiro: Sextante, p. 74-89, 2003.

GOUVEIA, N., FLETCHER, T.: Time series analysis of air pollution and mortality: effects by cause, age and socioeconomic status. J Epidemiol Community Health 2000. Disponível em: < http://jech.bmj.com/cgi/reprint/54/10/750?ck=nck>.Acessado em: 23 nov. 2007.

HOBBS, P. V.: Introduction to Atmosferic Chemistry. Cambridge University Press, 2000. 262 (ISBN 0-521-77143-9).

IPEA (Instituto de Pesquisas Econômicas Aplicadas), ANTP (Agência Nacional de Transportes Públicos): IPEA e ANTP Avaliam o Impacto dos Congestionamentos. Disponível em: <http://72.14.209.104/search?q=cache:ckdNrrsuip0J:www.ntu.org.br>. Acessado em 13 out. 2007.

JACOB, D. J.: Introduction to Atmospheric Chemistry. Harvard University. Princeton University Press. Princeton, New Jersey. January 1999. 267p.

JAAKKO PÖYRY ENGENHARIA LTDA - Relatório de Impacto Ambiental -Capuava Cogeração (2000).

JOHN ZINK Co.: John Zink Company LLC. Disponível em: <http://www.johnzink.com/products/burners/html_todd/burn_todd_pr_rmb.htm>. Acessado em: 13 mar. 2008 
LANDAU, J. L.: Chevron USA v. NRDC: The Supreme Court declines to burst EPA`s Bubble Concept. Copyright (c) 1985 Environmental Law Northwestern School of Law Lewis \& Clarck College, vol.15, 285p.

MAGE, D., OZOlinS, G., PETERSON, P., WEBSAR, A., ORTHOFER, R., VANDERWEERD, V., GWYNNE, M.: Urban Air Pollution in Megacities of the World, WHO-World Health Organization, 1995.

MAYER, H.: Air Pollution in cities. Meteorological Institute. University of Freiburbg. Germany. 1999.

ODUM, E. P.: Ecologia. $3^{a}$ edição. Rio de Janeiro (RJ). Guanabara Koogan S.A., 1988.

ODUM, H. T., ODUM, E.C., BROWN, M.T., LAHART, D., BERSOK, C., SENDZIMIR, J., SCOTT, G. B., et al.: Environmental Systems and Public Policy. Ecological. Economics Program. University of Florida. USA. 1988.

Disponível em <http://www.unicamp.br/fea/ortega/eco/index.htm>. Acessado em: 10 set. 2007

OFFE, Claus.: Tese sobre a fundanmentação do conceito de "Estado Capitalista" e sobre a pesquisa política de orientação materialista, 1984

PERKINS, H.C.: Air Pollution. New York. Mv Graw-Hill, 1974.

PHILIPPI Jr., A.; ROMERO, M.A.; BRUNA, G.C.: Curso de Gestão Ambiental. Coleção Ambiental. Universidade de São Paulo. Faculdade de Saúde Pública, Faculdade de Arquitetura e Urbanismo, Núcleo de Informações em Saúde Ambiental. Barueri, São Paulo 2004.

T

REIS, L. B. Geração de Energia Elétrica. São Paulo: Ed. Tec-Art, 1998.

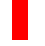
RICKLETS, R.E.: A economia da natureza. $3^{a}$ edição. Rio de Janeiro (RJ). Guanabara Koogan S.A. 1996. 
RUSSO, P. R.: Poluição atmosférica: Refletindo sobre a qualidade ambiental em áreas urbanas. Disponível em:

<http://www.educacaopublica.rj.gov.br/biblioteca/biologia>. Acessado em: 28 abr.2007

SALDIVA, P. H., BRAGA, A. L. F., PEREIRA L. A., MENEZES J. J., CONCEIÇÃO G. M., LIN C. A., et al.: Health effects of air pollution exposure on children and adolescentes in São Paulo, Brazil. Pediatr Pulmonol 2001a.

SALDIVA, P. H., BRAGA, A. L. F., MARTINS, L. C., LATORRE, M. R. D. O: Relação entre poluição atmosférica e atendimentos por infecção de vias aéreas superiores no município de São Paulo: avaliação do rodízio de veículos. Revista Brasileira de Epidemiologia. Print ISSN 1415-790X. vol.4, n.3, São Paulo. Nov. 2001

Disponível em: <http://www.scielo.br/scielo.php?pid=S1415790X2001000300008\&script=sci_arttext\&tlng=en>. Acessado em: 05 dez.2007b.

SANTOS, E. L., SALVADOR, N. N. B.: Avaliação do "Conceito Bolha" como Critério de Compensação Ambiental em Atividades Poluidoras do Ar Atmosférico - Estudo de Caso no Estado de São Paulo. Revista Ceciliana, ISSN $1517-6363$, NN$^{\circ} .22,2004$, pags. $55-80$

SEARA FILHO, G. Informação recebida do Secretário Executivo do CONSEMA, 08 jan. 2008 (informação pessoal)

SIENFELD, J. H.; SPYROS N. P.: Atmospheric Chemistry And Physics: form air pollution to climate change. Second Edition, New Jersey (USA), 2006. 1203p. (ISBN 978-0-471-72017-1 e ISBN 0-471-72017-8)

SIQUEIRA, L.: Noções Básicas sobre Poluição do Ar e Usinas Termelétricas à Gás. São Paulo, Apostila CETESB, 2002.

SMA, Secretaria de Estado do Meio Ambiente: 21 Projetos Ambientais Estratégicos. In: Projeto Respira São Paulo. Disponível em <http://www.ambiente.sp.gov.br/21projetos/default.asp\#19> acessado em: 12 dez.2007 
SOLER, F.D.: Os Créditos de Emissões Atmosféricas Reduzidas (CEAR's) e o Mercado Paulista de Emissões Atmosféricas (MPEA). REVISTA DIGITAL DO ESCRITÓRIO PINHEIRO PEDRO ADVOGADOS, edição 10 - dezembro 2006. Disponível em: <http://www.dazibao.com.br/boletim/0010/jur_fabricio.htm> Acessado em 04 dez. 2008

STILING, P.D.: Ecology: theories and applications. 4th edition. New Jersey, USA: Prentice Hall; 2002.

USEPA (United States Environmental Protection Agency). Handbook for Criteria Pollutant Inventory Development: A Beginner's Guide for Point and Area Sources. September 1999. 285p. Disponível em <http://www.epa.gov/ttn/chief >. Acessado em: 08 jan. 2008

WAKAMATSU, S.: Photochemical Air Pollution. Course of Air Quality Management Policy II (13/02/2006), Japan International Cooperation Agency -JICA, Tóquio 2006

\section{Documentos Jurídicos}

BRASIL. Resolução CONAMA $\mathbf{n}^{\circ}$ 003, de 28 de junho de 1990. Dispõe sobre padrões de qualidade do ar, previstos no PRONAR. Data da legislação: 28/06/1990 Publicação DOU: 22/08/1990. Disponível em: <http://www.mma.gov.br/port/conama/legiano.cfm?codlegitipo=3>. Acessado em: 02 jan. 2008

BRASIL. Resolução CONAMA n 357, de 18 de março de 2005. Dispõe sobre a classificação dos corpos de água e diretrizes ambientais para o seu enquadramento, bem como estabelece as condições e padrões de lançamento de efluentes, e dá outras providências. Data da legislação: 17/03/2005 - Publicação DOU: 18/03/2005 Disponível em: <http://www.mma.gov.br/port/conama/legiano.cfm?codlegitipo=3> . Acessado em: 02 jan. 2008

BRASIL. Resolução CONAMA n 382, de 02 de janeiro de 2006. Estabelece os limites máximos de emissão de poluentes atmosféricos para fontes fixas. Data da legislação: 26/12/2006 - Publicação DOU: 02/01/2007. Disponível em: 
<http://www.mma.gov.br/port/conama/legiano.cfm?codlegitipo=3>. Acessado em: 02 jan. 2008

BRASIL. Lei $\mathbf{n}^{\circ}$ 6.938, de 31 de outubro de 1981. Define a Política Nacional do Meio Ambiente - SISNAMA - CONAMA - licenciamento - penalidades.

BRASIL. Decreto $n^{\circ}$ 4.297, de 10 de julho de 2002. Regulamenta o art. $9^{\circ}$, inciso II, da Lei $n^{\circ} 6.938$, de 31 de agosto de 1981, estabelecendo critérios para o Zoneamento Ecológico-Econômico do Brasil - ZEE.

SÃO PAULO (Estado). Decreto $\mathbf{n}^{\circ} \mathbf{8 . 4 6 8}$, de 08 de setembro de 1976. Aprova o regulamento da Lei n997/76 - controle da poluição das águas, ar, resíduos, padrões, exigências, licenciamento, penalidades. Alterado pelos Decretos $n^{\circ} 12.045 / 78$; $15.425 / 80 ; 17.299 / 81 ; 18.386 / 82 ; 22.032 / 84 ; 23.128 / 84 ; 28.313 / 88 ; 28.429 / 88$; 29.027/88; 39.551/94; 43.594/98; 47.397/02, 48.523/04, 50.753/06 e 52.469/07.

SÃO PAULO (Estado). Decreto $n^{\circ}$ 47.397, de 04 de dezembro de 2002. Dá nova redação ao Título $\vee$ e ao Anexo 5 do Decreto $n^{\circ} 8.468$, de 08.09.76.

SÃO PAULO (Estado). Decreto $\mathbf{n}^{\circ}$ 47.400, de 04 de dezembro de 2002. Regulamenta dispositivos da Lei Estadual $n^{\circ} 9.509$, de 20 de março de 1997, referentes ao licenciamento ambiental, estabelece prazos de validade para cada modalidade de licenciamento ambiental e condições para sua renovação, estabelece prazo de análise dos requerimentos e licenciamento ambiental, institui procedimento obrigatório de notificação de suspensão ou encerramento de atividade, e o recolhimento de valor referente ao preço de análise.

SÃO PAULO (Estado). Decreto $\mathrm{n}^{\circ}$ 48.523, de 02 de março de 2004. Introduz alterações no Regulamento da Lei n997, de 31.0576, aprovado pelo Decreto n8.468, de 08.09.76 e suas alterações posteriores, que dispõe sobre a prevenção e o controle da poluição do meio ambiente.

SÃO PAULO (Estado). Decreto $\mathbf{n}^{\circ} \mathbf{5 0 . 7 5 3}$, de 28 de abril de 2006. Altera a redação e inclui dispositivos no Regulamento aprovado pelo Decreto n. 8.468, de 08.09.76, disciplinando a execução da Lei n997, de 31.05.76, que dispõe sobre controle da 
poluição do meio ambiente. (Alterados: Inciso II do art. 60; art. 23; art. 24; art. 42. Incluídos: art. 42-A; art. 42-B; incisos VI a IX no art. 74; § $2^{\circ}$ no art. 85 e, Anexo 11).

SÃO PAULO (Estado). Decreto $\mathbf{n}^{\circ}$ 52.469, de 12 de dezembro de 2007. Altera a redação de dispositivos do Regulamento aprovado pelo Decreto $\mathrm{n}^{0} 8.468$, de 8 de setembro de 1976, que dispõe sobre o controle da poluição do meio ambiente, confere nova redação ao artigo $6^{\circ}$ do Decreto n50.753, de 28 de abril de 2006, e dá providências correlatas.

SÃO PAULO (Estado). Lei $\mathbf{n}^{\circ}$ 997, de 31 de maio de 1976. Dispõe sobre o controle da poluição do meio ambiente no Estado de são Paulo. (Alteradas pelas Leis n ${ }^{\circ}$ 8.943/94 e $9.477 / 96$

SÃO PAULO (Estado). Lei $\mathbf{n}^{\circ} \mathbf{1 . 8 1 7}$, de 27 de outubro de 1978. RMSP - zoneamento industrial metropolitano - localização, classificação, licenciamento.

SÃO PAULO (Estado). Lei $\mathbf{n}^{\circ} \mathbf{1 1 . 2 4 3}$, de 10 de outubro de 2002. Altera os artigos 15 e 19 e revoga o art. 16 da Lei $n^{\circ} 1.817$, de 27.10.78, que estabelece os objetivos e as diretrizes para o desenvolvimento industrial metropolitano e disciplina o zoneamento industrial, a localização, a classificação e o licenciamento de estabelecimentos industriais na Região Metropolitana da Grande São Paulo. Também revoga a Lei $\mathrm{n}^{\circ} 11.217$, de 24.07.02.

SÃO PAULO (Estado). Resolução SMA n 66, de 17 de dezembro de 1996. Garante o acesso público aos processos administrativos que tratem de matéria ambiental e o direito à informações dessa natureza. 


\title{
ANEXO 1 - DECRETO N. 48.523, DE 02 DE MARÇO DE 2004
}

\author{
Introduz alterações no Regulamento da Lei no 997, de 31 de maio de 1976, aprovado pelo Decreto $n^{\circ} 8.468$, \\ de 8 de setembro de 1976 e suas alterações posteriores, que dispõe sobre a prevenção e o controle da \\ poluição do meio ambiente e dá providências correlatas
}

GERALDO ALCKMIN, Governador do Estado de São Paulo, no uso de suas atribuições legais,

Decreta:

Artigo $1^{\circ}$ - Os dispositivos a seguir relacionados do Regulamento da Lei $n^{\circ} 997$, de 31 de maio de 1976, aprovado pelo Decreto $n^{\circ}$ 8.468, de 8 de setembro de 1976 e suas alterações posteriores, passam a vigorar com a seguinte redação:

I - o inciso II do artigo 60:

"Il - efetuar levantamento organizado e manter o cadastro das fontes de poluição e inventariar as fontes prioritárias de poluição a critério da CETESB;"; (NR)

II - 0 artigo 23:

"Artigo 23 - Determina-se o grau de saturação da qualidade do ar de uma sub-região quanto a um poluente específico, cotejando-se as concentrações nela verificadas com os padrões de qualidade do ar estabelecidos no artigo 29 deste Regulamento.

Parágrafo único - As sub-regiões a que se refere este artigo, serão classificadas de acordo com os seguintes critérios:

1. consideram-se como áreas em vias de saturação aquelas sub-regiões em que:

a) o valor da média das concentrações dos 3 (três) últimos anos, de um determinado poluente, exceder a 90\% (noventa por cento) dos correspondentes padrões anuais de qualidade do ar;

b) para os padrões de curto prazo, assim considerados aqueles expressos em horas, se 3 (três) ou mais valores de concentração excederem a 90\% (noventa por cento) do padrão correspondente segundo os valores obtidos nos últimos 3 (três) anos;

2. consideram-se como áreas saturadas as sub-regiões em que:

a) o valor da média das concentrações dos últimos 3 (três) anos de um determinado poluente, ultrapassar os padrões anuais de qualidade do ar;

b) no caso de padrões de curto prazo, assim considerados aqueles expressos em horas, se, em mais de 3 (três) dias, os valores de concentração excederem o padrão correspondente nos últimos 3 (três) anos;

3. nas sub-regiões em que não houver estações de medição de qualidade do ar, o órgão ambiental poderá, a seu critério, com base nos dados disponíveis sobre as fontes já instaladas e as características da região, classificá-las como áreas em vias de saturação ou áreas saturadas.";(NR)

III - o artigo 24:

"Artigo 24 - Nas sub-regiões em vias de saturação e nas já saturadas, a CETESB poderá fazer exigências especiais para as atividades que se encontram em operação, tendo por fundamento metas, planos e programas de prevenção e controle da poluição, quer na renovação da licença de operação, quer durante sua vigência.";(NR)

IV - o artigo 42:

"Artigo 42 - Para o licenciamento da instalação ou da operação de novas fontes de poluição ou no caso da ampliação das já existentes em sub-região com qualquer grau de saturação, deverão ser consideradas as exigências contidas nos programas de recuperação e melhoria da qualidade do ar.

$\S 1^{\circ}$ Os programas tratados neste artigo considerarão a compensação das emissões com ganho ambiental, para possibilitar a inclusão de novas fontes de poluição do ar em sub-regiões saturadas ou em vias de saturação, resguardados os padrões de qualidade do ar, cabendo à CETESB somente analisar e aprovar os projetos apresentados, desde que estejam em conformidade com os critérios legais pertinentes.

§ $2^{\circ}$ Para fins da compensação prevista no parágrafo anterior, serão elegíveis as fontes de poluição já instaladas na sub-região do novo empreendimento e, no caso de impossibilidade técnica, em sub-região contígua, a critério da CETESB.

$\S 3^{\circ}$ As fontes de poluição já instaladas, para os efeitos do disposto no parágrafo anterior, deverão adequar sua licença ambiental já emitida, documentando a forma de redução a ser efetuada de acordo com os procedimentos a serem estabelecidos pela CETESB e demais órgãos pertinentes do SEAQUA, quando for o caso.

$\S 4^{\circ}$ Para o efeito do disposto no "caput" deste artigo, além da utilização da melhor tecnologia prática disponível, ficam estabelecidos como exigências mínimas os seguintes critérios:

1. nas sub-regiões em vias de saturação, caso o total das novas emissões exceda a 30 (trinta) toneladas por ano e por poluente específico, o licenciamento ambiental dependerá de compensação de $100 \%$ (cem por cento) das emissões adicionadas desse poluente;

2. nas sub-regiões saturadas, o licenciamento ambiental dependerá de compensação de $110 \%$ (cento e dez por cento) das emissões adicionadas.

$\S 5^{\circ}$ No processo de licenciamento ambiental, o empreendedor deverá: 
1. quando se tratar de poluentes primários, demonstrar por meio de modelos matemáticos aceitos pela CETESB, que a concentração anual máxima estimada não será superior a 90\% (noventa por cento) do padrão de qualidade do ar, tomando-se como concentração de fundo, o valor médio das concentrações do poluente obtidas em todas as estações da sub-região, nos últimos 3 (três) anos;

2. para os poluentes secundários, comprovar que o balanço de massas de cada um dos precursores efetuados entre a estimativa de emissão das novas fontes e a da retirada da emissão de fontes já existentes, atende aos critérios de compensação previstos no $\S 3^{\circ}$ deste artigo.". (NR)

Artigo $2^{\circ}$ - Ficam acrescentados os parágrafos $3^{\circ}, 4^{\circ}, 5^{\circ}$ e $6^{\circ}$ ao artigo 20 do Regulamento da Lei $n^{\circ}$ 997, de 31 de maio de 1976, aprovado pelo Decreto $n^{\circ}$ 8.468, de 8 de setembro de 1976 e posteriores alterações, com a seguinte redação:

"§ $3^{\circ} \mathrm{A}$ sub-região de gerenciamento da qualidade do ar para os poluentes primários é o território do município, exceto no caso de conurbação em que a sub-região compreenderá todos os municípios conurbados.

$\S 4^{\circ}$ Considera-se como sub-região de gerenciamento da qualidade do ar para os poluentes secundários, toda a área que diste até $30 \mathrm{Km}$ de qualquer estação que gere dados validados pela CETESB, podendo esta alterar o contorno da área mediante decisão motivada.

$\S 5^{\circ}$ No caso de estação não operada pela CETESB, sua validação implicará a verificação da adequabilidade do local em que ela estiver instalada, dos procedimentos operacionais e da manutenção dos equipamentos utilizados.

$\S 6^{\circ}$ Para os efeitos deste Regulamento, consideram-se:

1. poluentes primários aqueles diretamente emitidos pelas fontes de poluição, tais como, partículas em suspensão, monóxido de carbono, dióxido de enxofre e dióxido de nitrogênio;

2. poluentes secundários, aqueles formados a partir de reações entre outros poluentes.".

Artigo $3^{\circ}$ - A CETESB adotará as providências necessárias com vista à perfeita execução do presente decreto.

Artigo $4^{\circ}$ Este decreto entra em vigor 180 (cento e oitenta dias) dias após sua publicação.

Palácio dos Bandeirantes, 2 de março de 2004

GERALDO ALCKMIN

(D.O.E Executivo, de 03.03.04)

\section{ANEXO 2 - DECRETO N. 50.753, DE 28 DE ABRIL DE 2006}

Altera a redação e inclui dispositivos no Regulamento aprovado pelo Decreto n. 8.468 , de 8 de setembro de 1976, disciplinando a execução da Lei $n^{\circ}$ 997, de 31 de maio de 1976, que dispõe sobre controle da poluição do meio ambiente e dá providências correlatas

CLÁUDIO LEMBO, Governador do Estado de São Paulo, no uso de suas atribuições legais,

Decreta:

Artigo $1^{\circ}$ - Os dispositivos a seguir relacionados do Regulamento da Lei $n^{\circ} 997$, de 31 de maio de 1976, aprovado pelo Decreto $\mathrm{n}^{\circ}$ 8.468, de 8 de setembro de 1976, e suas alterações posteriores, passam a vigorar com a seguinte redação:

I - o inciso II do artigo $6^{\circ}$ :

"II - efetuar levantamento organizado e manter o cadastro das fontes de poluição e inventariar as fontes prioritárias - fixas e móveis - de poluição, segundo metodologias reconhecidas internacionalmente, a serem adotadas a critério da CETESB." (NR)

II - o artigo 23:

"Artigo 23 - Determina-se o grau de saturação da qualidade do ar de uma sub-região quanto a um poluente específico, cotejando-se as concentrações verificadas nos últimos 3 (três) anos com os Padrões de Qualidade do $\operatorname{Ar}$ (PQAR) estabelecidos no artigo 29 deste Regulamento e na Resolução CONAMA n $3 / 90$ ou regulamentação correlata superveniente. critérios:

$\S 1^{0}$ - As sub-regiões a que se refere este artigo, serão classificadas de acordo com os seguintes

1. para exposição de longo prazo:

a) sub-regiões com 3 (três) anos representativos:

1. saturada (SAT): média aritmética das médias anuais dos últimos 3 (três) anos maior que o PQAR;

2. em Vias de Saturação (EVS): média aritmética das médias anuais dos últimos 3 (três) anos maior que $90 \%$ (noventa por cento) do PQAR; 90\% do PQAR

3. não Saturada (NS): média aritmética das médias anuais dos últimos 3 (três) anos menor ou igual a

b) sub-regiões com 2 (dois) anos representativos:

1. SAT: média aritmética das médias anuais dos 2 (dois) anos maior que $90 \%$ (noventa por cento) do PQAR:

PQAR;

2. EVS: média aritmética das médias anuais dos 2 (dois) anos maior que $80 \%$ (oitenta por cento) do 
3. NS: média aritmética das médias anuais dos 2 (dois) anos menor ou igual a 80\% (oitenta por cento) do PQAR;

c) sub-regiões com 1 (um) ano representativo:

1. SAT: média anual maior que $90 \%$ (noventa por cento) do PQAR;

2. EVS: média anual maior que $80 \%$ (oitenta por cento) do PQAR;

3. NS: média anual menor ou igual a $80 \%$ (oitenta por cento) do PQAR;

2. para exposição de curto prazo:

a) sub-regiões com 3 (três) anos representativos:

1. SAT: $4^{\circ}$ maior valor diário dos últimos 3 (três) anos maior que o PQAR;

2. EVS: $3^{\circ}$ maior valor diário dos últimos 3 (três) anos maior que $90 \%$ (noventa por cento) do PQAR;

3. NS: $3^{\circ}$ maior valor diário dos últimos 3 (três) anos menor ou igual a 90\% (noventa por cento) do PQAR;

b) sub-regiões com 2 (dois) anos representativos: 1. SAT: $3^{\circ}$ maior valor diário dos últimos 3 (três) anos maior que o PQAR;

2. EVS: $2^{\circ}$ maior valor diário dos últimos 3 (três) anos maior que $90 \%$ (noventa por cento) do PQAR;

3. NS: $2^{\circ}$ maior valor diário dos últimos 3 (três) anos menor ou igual a 90\% (noventa por cento) do PQAR;

c) sub-regiões com 1 (um) ano representativo: 1 . SAT: $2^{\circ}$ maior valor diário dos últimos 3 (três) anos maior que o PQAR;

2. EVS: $1^{\circ}$ maior valor diário dos últimos 3 (três) anos maior que $90 \%$ (noventa por cento) do PQAR; PQAR;

3. NS: $1^{\circ}$ maior valor diário dos últimos 3 (três) anos menor ou igual a $90 \%$ (noventa por cento) do

d) sub-regiões com nenhum ano representativo: 1 . SAT: $2^{\circ}$ maior valor diário dos últimos 3 (três) anos maior que o PQAR;

2. EVS: $1^{\circ}$ maior valor diário dos últimos 3 (três) anos maior que $90 \%$ (noventa por cento) do PQAR;

3. onde não se aplicarem as disposições anteriores por ausência de dados de monitoramento, a CETESB poderá classificar as sub-regiões quanto ao grau de saturação com base nos dados disponíveis sobre as fontes já instaladas, nas características da região e, se necessário, no uso de modelos de dispersão.

$\S 2^{\circ}$ - Para efeito de aplicação deste artigo, considera-se o seguinte:

1. ano representativo: aquele cujo número de valores diários válidos de amostragem da qualidade do ar em cada quadrimestre seja maior que 50\% (cinqüenta por cento) do total amostrado, respeitadas as metodologias de freqüência de amostragem;

2. média anual válida de amostragem da qualidade do ar: somente aquela obtida em ano representativo;

3. valor diário válido de amostragem da qualidade do ar: valor obtido em dia em que 2/3 (dois terços) dos dados horários são válidos;

4. dado horário válido: aquele que foi submetido a análise técnica e validado, pela CETESB;

5. médias anuais de valores de amostragem da qualidade do ar: médias calculadas nos termos do artigo 29 deste Regulamento e na Resolução CONAMA n 3/90, ou regulamentação correlata superveniente;

6. valor diário de cada poluente: concentração máxima verificada no dia, observados os tempos de exposição dos padrões de curto prazo estabelecidos no artigo 29 deste Regulamento e na Resolução CONAMA n $3 / 90$, ou regulamentação correlata superveniente." (NR)

III - 0 artigo 24:

"Artigo 24 - Nas sub-regiões em vias de saturação e nas já saturadas, a Companhia de Tecnologia de Saneamento Ambiental - CETESB estabelecerá um Programa de Redução de Emissões Atmosféricas PREA para os empreendimentos que se encontrem em operação.

$\S 1^{\circ}$ - Serão integrantes do PREA os empreendimentos que se enquadrem nos critérios estabelecidos no Anexo 11 deste Regulamento.

$\S 2^{\circ}$ - A renovação da Licença de Operação dos empreendimentos integrantes do PREA condicionase às seguintes exigências técnicas especiais: disponível;

1. a utilização de sistemas de controle de poluição do ar baseados na melhor tecnologia prática

2. a implementação de Plano de Monitoramento das Emissões Atmosféricas, segundo Termos de Referência estabelecidos pela CETESB;

3. o cumprimento de metas de redução de emissões, em termos de prazo e quantidade, estabelecidas pela CETESB para empreendimentos localizados em sub-regiões SAT:

a) as metas de redução de emissão serão estabelecidas tomando por base a contribuição relativa do empreendimento no inventário das fontes de poluição da respectiva sub-região;

b) a cada renovação da Licença de Operação a meta de redução poderá ser revista tendo por base o atingimento da meta anterior;

c) para o cumprimento das metas de reduções de emissões poderá ser utilizado o mecanismo de compensação de emissões por poluente, estabelecido no artigo 42-A, acrescentado por este decreto.". (NR)

IV - a alínea b do inciso I do artigo 29:

"b) 240 (duzentos e quarenta) microgramas por metro cúbico de partículas em suspensão, ou valor inferior - concentração média de 24 (vinte e quatro) horas consecutivas, não podendo ser ultrapassada mais de uma vez por ano." (NR) 
V - o artigo 42:

"Artigo 42 - Fontes novas de poluição ou no caso da ampliação das já existentes que pretendam instalar-se ou operar, quanto à localização, serão:

I - proibidas de instalar-se ou de operar quando, a critério da CETESB, houver o risco potencial a que alude $\mathrm{o}$ inciso $\mathrm{V}$ do artigo $3^{\circ}$ deste Regulamento, ainda que as emissões provenientes de seu processamento estejam enquadradas nos incisos I, II, III e IV do mesmo artigo;

II - quando localizarem-se em regiões SAT e EVS e aludidas no anexo 11, obrigadas a compensar, conforme estabelecido no artigo 42-A acrescentado por este decreto, em $110 \%$ (cento e dez por cento) e $100 \%$ (cem por cento) das emissões atmosféricas a serem adicionadas dos poluentes que causaram os estados, respectivamente, de SAT ou EVS.

Parágrafo único - Para os fins de que trata o inciso II deste artigo, para empreendimentos localizados em municípios pertencentes a mais de uma sub-região, a compensação de emissões poderá ser efetuada entre os empreendimentos situados em qualquer dessas sub-regiões, considerando as exigências previstas para a sub-região." (NR)

Artigo $2^{\circ}$ - Ficam acrescentados os $\S \S 3^{\circ}$ e $4^{\circ}$ ao artigo 20 do Regulamento da Lei $n^{\circ} 997$, de 31 de maio de 1976, aprovado pelo Decreto $\mathrm{n}^{\circ}$ 8.468, de 8 de setembro de 1976, e posteriores alterações, com a seguinte redação:

"§ $3^{\circ}$ - A abrangência da sub-região de gerenciamento da qualidade do ar onde houver estação de medição da qualidade do ar será:

1. para o ozônio, o território compreendido pelos municípios que, no todo ou em parte, estejam situados a uma distância de até $30 \mathrm{~km}$ da estação de monitoramento da qualidade do ar;

2. para os demais poluentes, o território do município onde está localizada a estação de monitoramento da qualidade do ar;

3. nos casos de conurbação, a CETESB poderá, mediante decisão tecnicamente justificada, ampliar a área compreendida pela sub-região, de modo a incluir municípios vizinhos.

$\S 4^{\circ}$ - No caso de estação de medição da qualidade do ar não operada pela CETESB, a validação dos dados implicará na verificação da adequabilidade do local em que ela estiver instalada, dos procedimentos operacionais e da manutenção dos equipamentos utilizados, conforme diretrizes e procedimentos estabelecido pela CETESB.".

Artigo $3^{\circ}$ - Ficam acrescentados os artigo 42-A e 42-B ao Regulamento da Lei $n^{\circ}$ 997, de 31 de maio de 1976, aprovado pelo Decreto $n^{\circ} 8.468$, de 8 de setembro de 1976, e posteriores alterações, com a seguinte redação:

"Artigo 42-A - A compensação prevista nos artigos 24 e 42 dar-se-á pela geração e utilização de crédito de emissões reduzidas.

$\S 1^{\circ}$ - A geração de crédito, em fontes fixas, dar-se-á mediante a redução de emissões dos poluentes que levaram à saturação, em qualquer grau, da sub-região:

1. em sub-regiões EVS e SAT, para o ozônio, a compensação de emissões dar-se-á por cada categoria de seus precursores, quais sejam, óxidos de nitrogênio (NOx) e compostos orgânicos voláteis (COVs), excluído o metano ( $\mathrm{CH} 4)$;

2. a redução de emissões em fontes fixas deverá ser comprovada por meio de medições efetuadas antes e, com exceção dos casos de desativação de fontes, depois das alterações realizadas;

3. a validação dos resultados de medições realizadas por empreendedores ou por terceiros, fica condicionada ao atendimento dos procedimentos estabelecidos pela CETESB;

4. excepcionalmente, na ausência de procedimentos para medições de emissões, as reduções poderão ser comprovadas mediante utilização de métodos ou fatores de emissões baseados na literatura internacional e reconhecidos pela CETESB.

$\S 2^{\circ}$ - As reduções permanentes de emissão em fontes fixas serão convertidas em créditos aplicando-se o fator de conversão 1,0 para sub-regiões EVS e 0,6 para sub-regiões SAT.

$\S 3^{\circ}$ - A geração do crédito em fontes fixas será efetivada no processo de renovação da Licença de Operação ou do licenciamento das alterações do processo produtivo, bem como por ocasião da desativação de fontes, atendidos os critérios de conversibilidade de reduções de emissões estabelecidos neste artigo:

1. A titularidade do crédito dar-se-á pelo registro, por parte da CETESB, na Licença de Operação, de acordo com o seguinte:

a) constarão da Licença de Operação a data de expiração do crédito, o poluente a que se refere e seu valor em toneladas por ano e em quilos por hora;

b) o crédito refere-se, inicialmente, ao empreendimento gerador da redução das emissões, podendo ser transferido total ou parcialmente entre empreendimentos localizados na mesma sub-região.

2. a geração de crédito deverá ser solicitada pelo interessado previamente à implantação das alterações redutoras de emissões.

3. o crédito gerado por fontes fixas terá validade de 10 (dez) anos, extinguindo-se em duas situações:

a) quando da expiração de sua validade;

b) no momento de sua utilização.

$\S 4^{\circ}$ - A compensação de emissões ocorrerá apenas entre fontes localizadas em uma mesma subregião, devendo ser comprovada pelo balanço de massas em toneladas/ano, entre a estimativa da emissão da(s) nova(s) fonte(s) e a emissão registrada no crédito a ser utilizado, sem prejuízo ao inciso I do artigo 42 deste decreto, respeitadas também as seguintes condições: 
1. para sub-regiões classificadas como EVS ou SAT em função dos padrões de curto prazo, a compensação entre fontes fixas também deverá ser comprovada pelo balanço de massas em quilogramas por hora;

2. a utilização de créditos por empreendimentos que não detenham sua titularidade depende da anuência do(s) detentor(es) de crédito(s), formalizada em documento que a autorize perante a CETESB;

3. a diferença de cotas (altitude) dos empreendimentos envolvidos na compensação deverá ser inferior a 400 metros.

$\S 5^{\circ}$ - Os créditos gerados por fontes móveis poderão ser efetivados mediante reduções de emissões de poluentes em frotas cativas, que comprovadamente circulem na sub-região onde o crédito será utilizado:

1. a geração de crédito será autorizada somente após a constatação pela CETESB da efetiva implantação das medidas de redução das emissões da frota, respeitada a legislação vigente relativa às emissões de gases, partículas e ruído externo e atendida a capacidade operacional da frota.

2. entende-se por frota cativa aquela composta por veículos licenciados no Estado de São Paulo e de propriedade de uma única empresa ou entidade de transporte coletivo de passageiros, carga ou outra atividade, caracterizada pela uniformidade da operação, do serviço e área de circulação.

3. a atribuição de fatores de emissão das frotas para fins de cálculo das respectivas reduções de emissão será feita com base nos valores publicados pela CETESB, consideradas também as características tecnológicas das frotas.

4. os créditos serão calculados com base na quilometragem total rodada na sub-região onde o crédito será utilizado.

5. as reduções a que se refere o $\$ 5^{\circ}$ serão convertidas em créditos mediante multiplicação pelos seguintes fatores:

a) 0,9 (nove décimos) para substituição da frota existente por veículos novos menos poluentes;

b) 07 (sete décimos) para substituição dos motores existentes por motores novos menos poluentes; existentes;

c) 0,5 (cinco décimos) para instalação de equipamentos novos de controle de emissões nos veículos

6. a geração de crédito em fontes móveis deverá ser solicitada pelo interessado previamente à implantação das medidas de redução de emissões;

7. o crédito gerado em fontes móveis perderá sua validade se não utilizado em no máximo:

a) 5 (cinco) anos para o caso de substituição da frota por veículos novos, ou de sua motorização por motores novos;

b) 2 (dois) anos para o caso de instalação de equipamentos novos de controle de emissões em veículos existentes;

8. os equipamentos de controle de emissões citados nos incisos anteriores deverão ser certificados por órgãos competentes nacionais ou estrangeiros quanto à sua durabilidade e eficiência na redução das emissões, mediante procedimentos reconhecidos internacionalmente, sendo os testes de certificação realizados com combustível de especificação similar ao comercializado no Brasil;

9. os veículos existentes a serem substituídos para fins de geração de crédito devem ter comprovada sua operação na frota cativa por pelo menos três anos anteriormente à solicitação de geração de crédito;

10. o proprietário ou responsável legal pela frota cativa deverá, após aprovação da proposta técnica pela CETESB, assinar Termo de Compromisso, visando a manter em plena operação os novos veículos, motores ou equipamentos de controle de sua frota por pelo menos 5 (cinco) anos de acordo com as exigências definidas pela CETESB nesse Termo, sujeitando-se pelo seu descumprimento às penalidades previstas neste Regulamento;

11. em caso de necessidade de modificações da frota e/ou de sua operação, durante o período de 5 (cinco) anos, estas devem ser previamente autorizadas pela CETESB, de modo que resultem em reduções de emissões equivalentes ou superiores às previstas no Termo de Compromisso;

12. o Termo de Compromisso deve incluir obrigatoriamente:

a) declaração da quantidade de crédito e o respectivo prazo de validade.

b) a identificação e as especificações técnicas e características tecnológicas de cada veículo pertencente à frota objeto dos créditos e responsabilidade de que essas serão mantidas pelo prazo de 5 anos;

c) a região de operação da frota objeto dos créditos e responsabilidade de manutenção desta pelo prazo de 5 (cinco) anos;

d) as características operacionais da frota objeto dos créditos e responsabilidade de que essas serão mantidas pelo prazo de 5 (cinco) anos;

e) a responsabilidade de que quaisquer modificações na operação da frota, nas características tecnológicas que afetem as emissões, bem como na sua região de operação, só serão realizadas mediante prévia autorização da CETESB;

13. as penalidades por descumprimento às exigências do Termo de Compromisso incidirão individualmente sobre cada veículo em desconformidade autuado pelos agentes credenciados da CETESB;

14. constatada a infração, o agente credenciado da CETESB lavrará o Auto de Infração e Imposição de Penalidade de Multa, contendo a identificação do veículo, o local, hora e data da infração, o ato, fato ou omissão que resultou na infração, a penalidade aplicada e o prazo de no máximo 60 (sessenta) dias para a regularização das desconformidades encontradas, dando ciência ao proprietário ou responsável legal pela frota cativa; 
15. o recolhimento das multas aplicadas em decorrência deste dispositivo deverá ser feito em qualquer estabelecimento bancário da Caixa Econômica do Estado de São Paulo - CEESP - através de guia específica a ser definida pela CETESB, consultada a Secretaria de Estado da Fazenda;

16. os veículos objeto da compensação não estão isentos das exigências relacionadas com a emissão de fumaça de que trata o artigo 32 desse decreto;

17. não será renovada a licença de trânsito de veículo em débito de multas impostas por infração às disposições deste decreto.

Artigo 42-B - A Companhia de Tecnologia de Saneamento Ambiental - CETESB atualizará e publicará até março de cada ano, com base nos dados referentes ao período de janeiro a dezembro do ano anterior, as seguintes informações: compõem;

I - as classificações quanto ao grau de saturação das sub-regiões, assim como os municípios que as

II - o inventário das emissões atmosféricas de fontes fixas e móveis, por sub-região e para o Estado de São Paulo, identificando os principais empreendimentos emissores, por poluente; validade."

III - valor e titularidade dos créditos disponíveis nas sub-regiões, com os respectivos prazos de

Artigo $4^{\circ}$ - Fica renumerado como $\S 1^{\circ}$ o parágrafo único do artigo 85 do Regulamento da Lei $n^{\circ} 997$, de 31 de maio de 1976, aprovado pelo Decreto $n^{\circ} 8.468$, de 8 de setembro de 1976, ficando acrescentado o $\S$ $2^{\circ}$ com a seguinte redação:

"§ $2^{\circ}$ - Para as infrações às exigências do Termo de Compromisso de que trata o $\S 5^{\circ}$ do artigo $42-A$ acrescentado por este decreto, aplicam-se as seguintes disposições:

1. serão punidas com a multa de 600 (seiscentas) vezes o valor da Unidade Fiscal do Estado de São Paulo - UFESP, dobrando o valor nas reincidências;

2. a penalidade de multa será imposta quando da constatação do não atendimento às exigências técnicas referidas no Termo de Compromisso ou, em caso de reincidência, após o decurso do prazo concedido para sua correção, caso não tenha sido sanada a desconformidade;

3. o prazo concedido poderá ser dilatado, desde que requerido fundamentadamente pelo infrator, antes de vencido o prazo anterior, sendo dada ciência ao infrator das decisões que concederem ou denegarem prorrogação;

4. caracteriza-se a reincidência quando ocorrer nova infração às exigências do Termo de Compromisso durante todo o período de vigência desse;

5. não se aplicam às infrações de que tratam os dispositivos anteriores as penalidades, procedimentos e demais requisitos constantes nos artigos 32, 80 a 84 e 86 a 96 deste Regulamento."

Artigo $5^{\circ}$ - Ficam acrescentados os incisos VI a IX ao artigo 74 do Regulamento da Lei $n^{\circ} 997$, de 31 de maio de 1976, aprovado pelo Decreto $n^{\circ} 8.468$, de 8 de setembro de 1976, e posteriores alterações, com a seguinte redação:

VI - análise de solicitação de crédito de compensação de emissões de poluentes atmosféricos por fontes fixas 250 (duzentas e cinqüenta) UFESP's;

VII - análise de solicitação de crédito de compensação de emissões de poluentes atmosféricos por fontes móveis 250 (duzentas e cinqüenta) UFESP's;

VIII - solicitação de registro de crédito de compensação de emissões de poluentes atmosféricos por fontes móveis 550 (quinhentas e cinqüenta) UFESP's;

IX - solicitação de transferência de créditos 35 (trinta e cinco) UFESP's."

Artigo $6^{\circ}$ - Excepcionalmente, para os períodos a seguir relacionados, vigorarão as seguintes regras:

I - para período compreendido entre a data de publicação deste decreto e 31 de dezembro de 2007:

a) será aplicado um fator multiplicador igual a 1,0 para converter reduções de emissões de fontes fixas em créditos em sub-regiões EVS e SAT;

b) as emissões de precursores de ozônio poderão ser compensadas com reduções em empreendimentos e frotas cativas localizados em qualquer município do Estado de São Paulo;

c) as emissões de poluentes primários poderão ser compensadas com reduções em empreendimentos e frotas cativas localizados na mesma sub-região ou em quaisquer municípios vizinhos;

d) as reduções comprovadas de emissões por fontes fixas, ocorridas no período de 3 (três) anos imediatamente anterior à data de publicação deste Decreto, poderão ser utilizadas pelo próprio empreendimento para compensar aumento de emissões, aplicando-se, no caso, o fator multiplicador de conversão 0,6 (seis décimos);

II - para o período entre janeiro de 2008 e dezembro de 2010:

a) será aplicado um fator multiplicador igual a 0,8 (oito décimos) para converter reduções de emissões por fontes fixas em créditos em sub-regiões SAT;

b) as emissões de precursores de ozônio poderão ser compensadas com reduções em empreendimentos e frotas cativas localizados em qualquer sub-região saturada em termos de ozônio;

c) as emissões de poluentes primários poderão ser compensadas com reduções em empreendimentos e frotas cativas localizados na mesma sub-região ou em quaisquer sub-regiões vizinhas, desde que saturadas.

Artigo $7^{\circ}$ - Fica acrescido ao Regulamento da Lei $n^{\circ}$ 997, de 31 de maio de 1976, aprovado pelo Decreto $\mathrm{n}^{\circ}$ 8.468, de 8 de setembro de 1976 o Anexo 11 conforme Anexo que integra o presente decreto. 
Artigo $8^{\circ}$ - Este decreto entra em vigor na data de sua publicação, aplicando-se aos processos em trâmite perante a Secretaria de Meio Ambiente, protocolizados a partir de $1^{\circ}$ de setembro de 2004.

Palácio dos Bandeirantes, 28 de abril de 2006

Anexo a que se refere o artigo $7^{\circ}$ do Decreto $n^{0} 50.753$, de 28 de abril de 2006

\section{ANEXO 11}

1. Serão integrantes do Programa de Redução de Emissões Atmosféricas (PREA) e obrigados a compensar as emissões adicionadas:

1.1. os empreendimentos cujo total de emissões é igual ou superior a:

a) Material Particulado (MP): 100 t/ano

b) Óxidos de Nitrogênio (NOx): 40 t/ano

c) Compostos Orgânicos Voláteis, exceto metano (COVs, não-CH4): 40 t/ano

d) Óxidos de Enxofre (SOx): 250 t/ano

e) Monóxido de Carbono (CO): 100 t/ano

1.2. os seguintes empreendimentos e atividades:

a) empresas automobilísticas e/ou aeronáuticas voláteis.

b) terminais e/ou bases de armazenamento, carga e descarga de combustíveis ou substâncias

2. Definições

a) emissões: liberação de substâncias para a atmosfera a partir de fontes pontuais ou difusas;

b) óxidos de Enxofre: óxidos de enxofre, expressos em dióxido de enxofre (SO2);

c) óxidos de Nitrogênio: óxido de nitrogênio e dióxido de nitrogênio, expresso em dióxido de nitrogênio (NO2);

d) Composto Orgânico Volátil (COV) Não- Metano: todo composto orgânico, exceto o metano (CH4), medido por um método de referência ou determinado por procedimentos estabelecidos pela CETESB.

(D.O.E de 29.04.06)

\section{ANEXO 3 - DECRETO N. 52.469, DE 12 DE DEZEMBRO DE 2007}

Altera a redação de dispositivos do Regulamento aprovado pelo Decreto $n^{\circ} 8.468$, de 8 de setembro de 1976, que dispõe sobre o controle da poluição do meio ambiente, confere nova redação ao artigo $6^{\circ}$ do Decreto $n^{\circ}$ 50.753, de 28 de abril de 2006, e dá providências correlatas

JOSÉ SERRA, GOVERNADOR DO ESTADO DE SÃO PAULO, no uso de suas atribuições legais,

Decreta:

Artigo $1^{\circ}$ - Os dispositivos a seguir relacionados do Regulamento da Lei $n^{\circ}$ 997, de 31 de maio de 1976, aprovado pelo Decreto $n^{\circ}$ 8.468, de 8 de setembro de 1976, e suas alterações posteriores, passam a vigorar com a seguinte redação:

I - O artigo 20:

"Artigo 20 - Para efeito de utilização e preservação do ar, o território do Estado de São Paulo fica dividido em Regiões, denominadas Regiões de Controle de Qualidade do Ar - RCQA.

$\S 1^{\circ}$ - As regiões a que se refere este artigo deverão coincidir com as Regiões Administrativas do Estado, estabelecidas no Decreto n 52.576, de 12 de dezembro de 1970, com suas alterações posteriores.

$\S 2^{\circ}$ - Para a execução de programas de controle da poluição do ar, qualquer Região de Controle de Qualidade do Ar poderá ser dividida em sub-regiões, constituídas de um, de dois ou mais Municípios, ou, ainda, de parte de um ou de partes de vários Municípios.

$\S 3^{\circ}$ - A abrangência da sub-região de gerenciamento da qualidade do ar onde houver estação de medição da qualidade do ar será:

1. para o ozônio, o território compreendido pelos municípios que, no todo ou em parte, estejam situados a uma distância de até $30 \mathrm{~km}$ da estação de monitoramento da qualidade do ar;

2. para os demais poluentes, o território do município onde está localizada a estação de monitoramento da qualidade do ar;

3. nos casos de conurbação, a CETESB poderá, mediante decisão tecnicamente justificada, ampliar a área compreendida pela sub-região, de modo a incluir municípios vizinhos.

$\S 4^{\circ}$ - No caso de estação de medição da qualidade do ar não operada pela CETESB, a validação dos dados implicará na verificação da adequabilidade do local em que ela estiver instalada, dos procedimentos operacionais e da manutenção dos equipamentos utilizados, conforme diretrizes e procedimentos estabelecido pela CETESB."; (NR)

II - O artigo 23:

"Artigo 23 - Determina-se o grau de saturação da qualidade do ar de uma sub-região quanto a um poluente específico, cotejando-se as concentrações verificadas nos últimos 3 (três) anos com os Padrões de 
Qualidade do $\operatorname{Ar}$ (PQAR) estabelecidos no artigo 29 deste Regulamento e na Resolução CONAMA n $3 / 90$ ou regulamentação correlata superveniente. critérios:

$\S 1^{0}$ - As sub-regiões a que se refere este artigo serão classificadas de acordo com os seguintes

1. para exposição de longo prazo:

a) sub-regiões com 3 (três) anos representativos:

1. saturada (SAT): média aritmética das médias anuais dos últimos 3 (três) anos maior que o PQAR;2. em Vias de Saturação (EVS): média aritmética das médias anuais dos últimos 3 (três) anos maior que $90 \%$ (noventa por cento) do PQAR; $90 \%$ do PQAR

3. não Saturada (NS): média aritmética das médias anuais dos últimos 3 (três) anos menor ou igual a

b) sub-regiões com 2 (dois) anos representativos:

1. SAT: média aritmética das médias anuais dos 2 (dois) anos maior que $90 \%$ (noventa por cento) do PQAR; PQAR;

2. EVS: média aritmética das médias anuais dos 2 (dois) anos maior que $80 \%$ (oitenta por cento) do

3. NS: média aritmética das médias anuais dos 2 (dois) anos menor ou igual a 80\% (oitenta por cento) do PQAR;

c) sub-regiões com 1 (um) ano representativo:

1. SAT: média anual maior que $90 \%$ (noventa por cento) do PQAR;

2. EVS: média anual maior que $80 \%$ (oitenta por cento) do PQAR;

3. NS: média anual menor ou igual a $80 \%$ (oitenta por cento) do PQAR;

2. para exposição de curto prazo:

a) sub-regiões com 3 (três) anos representativos:

1. SAT: $4^{\circ}$ maior valor diário dos últimos 3 (três) anos maior que o PQAR;

2. EVS: $3^{\circ}$ maior valor diário dos últimos 3 (três) anos maior que 90\% (noventa por cento) do PQAR;

3. NS: $3^{\circ}$ maior valor diário dos últimos 3 (três) anos menor ou igual a $90 \%$ (noventa por cento) do

PQAR;

b) sub-regiões com 2 (dois) anos representativos:

1. SAT: $3^{\circ}$ maior valor diário dos últimos 3 (três) anos maior que o PQAR;

2. EVS: $2^{\circ}$ maior valor diário dos últimos 3 (três) anos maior que $90 \%$ (noventa por cento) do PQAR;

3. NS: $2^{\circ}$ maior valor diário dos últimos 3 (três) anos menor ou igual a 90\% (noventa por cento) do

PQAR;

c) sub-regiões com 1 (um) ano representativo:

1. SAT: $2^{\circ}$ maior valor diário dos últimos 3 (três) anos maior que o PQAR;

2. EVS: $1^{\circ}$ maior valor diário dos últimos 3 (três) anos maior que $90 \%$ (noventa por cento) do PQAR;

3. NS: $1^{\circ}$ maior valor diário dos últimos 3 (três) anos menor ou igual a 90\% (noventa por cento) do PQAR;

d) sub-regiões com nenhum ano representativo:

1. SAT: $2^{\circ}$ maior valor diário dos últimos 3 (três) anos maior que o PQAR;

2. EVS: $1^{\circ}$ maior valor diário dos últimos 3 (três) anos maior que 90\% (noventa por cento) do PQAR;

3. onde não se aplicarem as disposições anteriores por ausência de dados de monitoramento, a CETESB poderá propor a classificação das sub-regiões quanto ao grau de saturação com base nos dados disponíveis sobre as fontes fixas já instaladas e as fontes móveis em circulação nas características da região e, se necessário, no uso de modelos de dispersão.

$\S 2^{\circ}$ - As sub-regiões consideradas saturadas serão classificadas, quanto a sua severidade, de acordo com os seguintes critérios:

1. para exposição de curto prazo:

a) Ozônio (O3)

1. Moderado: a segunda concentração máxima medida nos últimos três anos maior que 160 e menor ou igual a $200 \mu \mathrm{g} / \mathrm{m}^{3}$;

2. Sério: a segunda concentração máxima medida nos últimos três anos maior que 200 e menor ou igual a $240 \mu \mathrm{g} / \mathrm{m}^{3}$;

3. Severo: a segunda concentração máxima medida nos últimos três anos maior que $240 \mu \mathrm{g} / \mathrm{m}^{3}$.

b) Partículas inaláveis (MP10)

1. Moderado: a segunda concentração máxima medida nos últimos três anos maior que 150 e menor ou igual a $250 \mu \mathrm{g} / \mathrm{m}^{3}$;

2. Severo: a segunda concentração máxima medida nos últimos três anos maior que $250 \mu \mathrm{g} / \mathrm{m}^{3}$.

c) Partículas Totais em Suspensão (PTS)

1. Moderado: a segunda concentração máxima medida nos últimos três anos maior que 240 e menor ou igual a $375 \mu \mathrm{g} / \mathrm{m}^{3}$;

2. Severo: a segunda concentração máxima medida nos últimos três anos maior que $375 \mu \mathrm{g} / \mathrm{m}^{3}$.

d) Fumaça

1. Moderado: a segunda concentração máxima medida nos últimos três anos maior que 150 e menor ou igual a $250 \mu \mathrm{g} / \mathrm{m}^{3}$;

2. Severo: a segunda concentração máxima medida nos últimos três anos maior que $250 \mu \mathrm{g} / \mathrm{m}^{3}$. 
e) Monóxido de Carbono (CO)

1. Moderado: a segunda concentração máxima da média de 8 horas medida nos últimos três anos maior que 9 e menor ou igual a 15 ppm;

2. Severo: a segunda concentração máxima da média de 8 horas medida nos últimos três anos maior que $15 \mathrm{ppm}$.

f) Dióxido de Nitrogênio (NO2)

1. Moderado: a segunda concentração máxima medida nos últimos três anos maior que 320 e menor ou igual a $1130 \mu \mathrm{g} / \mathrm{m}^{3}$;

2. Severo: a segunda concentração máxima medida nos últimos três anos maior que $1130 \mu \mathrm{g} / \mathrm{m}^{3}$.

g) Dióxido de enxofre (SO2)

1. Moderado: a segunda concentração máxima medida nos últimos três anos maior que 365 e menor ou igual a $800 \mu \mathrm{g} / \mathrm{m}^{3}$;

2. Severo: a segunda concentração máxima medida nos últimos três anos maior que $800 \mu \mathrm{g} / \mathrm{m}^{3}$.

2. para exposição de longo prazo:

a) Partículas inaláveis (MP10)

1. Moderado: a concentração média máxima medida nos três últimos anos maior que 50 e menor ou igual a $70 \mu \mathrm{g} / \mathrm{m}^{3}$;

2. Severo: a concentração média máxima medida nos três últimos anos maior que $70 \mu \mathrm{g} / \mathrm{m}^{3}$.

b) Partículas Totais em Suspensão (PTS) $110 \mu \mathrm{g} / \mathrm{m}^{3}$

1. Moderado: a concentração média máxima medida nos três últimos anos maior que 80 e menor que

2. Severo: a concentração média máxima medida nos três últimos anos maior que $110 \mu \mathrm{g} / \mathrm{m}^{3}$.

c) Fumaça $80 \mu \mathrm{g} / \mathrm{m}^{3}$

1. Moderado: a concentração média máxima medida nos três últimos anos maior que 60 e menor que

2. Severo: a concentração média máxima medida nos três últimos anos maior que $80 \mu \mathrm{g} / \mathrm{m}^{3}$.

d) Dióxido de enxofre (SO2) $125 \mu \mathrm{g} / \mathrm{m}^{3}$;

1. Moderado: a concentração média máxima medida nos três últimos anos maior que 80 e menor que

2. Severo: a concentração média máxima medida nos três últimos anos maior que $125 \mu \mathrm{g} / \mathrm{m}^{3}$.

e) Dióxido de Nitrogênio (NO2)

1. Moderado: a concentração média máxima medida nos três últimos anos maior que 100 e menor que $160 \mu \mathrm{g} / \mathrm{m}^{3}$;

2. Severo: a concentração média máxima medida nos três últimos anos maior que $160 \mu \mathrm{g} / \mathrm{m}^{3}$.

$\S 3^{\circ}$ - Para efeito de aplicação deste artigo, considera-se o seguinte:

1. ano representativo: aquele cujo número de valores diários válidos de amostragem da qualidade do ar em cada quadrimestre seja maior que 50\% (cinqüenta por cento) do total amostrado, respeitadas as metodologias de freqüência de amostragem;

2. média anual válida de amostragem da qualidade do ar: somente aquela obtida em ano representativo;

3. valor diário válido de amostragem da qualidade do ar: valor obtido em dia em que 2/3 (dois terços) dos dados horários são válidos;

4. dado horário válido: aquele que foi submetido a análise técnica e validado, pela CETESB;

5. médias anuais de valores de amostragem da qualidade do ar: médias calculadas nos termos do artigo 29 deste Regulamento e na Resolução CONAMA n ${ }^{\circ} 3 / 90$, ou regulamentação correlata superveniente;

6. valor diário de cada poluente: concentração máxima verificada no dia, observados os tempos de exposição dos padrões de curto prazo estabelecidos no artigo 29 deste Regulamento e na Resolução CONAMA n $3 / 90$, ou regulamentação correlata superveniente.

$\S 4^{\circ}$ - As sub-regiões a que se refere este artigo serão classificadas anualmente, mediante Resolução do Secretário do Meio Ambiente, por proposta da CETESB aprovada pelo CONSEMA."; (NR)

III - O artigo 24:

"Artigo 24 - Nas sub-regiões em vias de saturação e nas já saturadas, a Companhia de Tecnologia de Saneamento Ambiental - CETESB estabelecerá um Programa de Redução de Emissões Atmosféricas PREA para os empreendimentos que se encontrem em operação.

$\S 1^{\circ}$ - Serão integrantes do PREA, além das fontes móveis, o conjunto de empreendimentos que integrem a classe $A$ da curva $A B C$, que será definida por subregião e calculada com base no inventário do(s) poluente(s) que gerou(ram) a saturação.

$\S 2^{\circ}$ - A renovação da Licença de Operação dos empreendimentos integrantes do PREA condicionase às seguintes exigências técnicas especiais:

1. a utilização de sistemas de controle de poluição do ar baseados na melhor tecnologia prática disponível, tanto para processos produtivos, como para equipamentos de controle propriamente ditos;

2. a implementação de Plano de Monitoramento das Emissões Atmosféricas, segundo Termos de Referência estabelecidos pela CETESB;

3. a partir de janeiro de 2013 , o cumprimento de metas de redução de emissões, em termos de prazo e quantidade, estabelecidas pela CETESB para empreendimentos localizados em sub-regiões SAT: 
a) as metas de redução de emissão serão estabelecidas tomando por base a contribuição relativa do empreendimento no inventário das fontes fixas e móveis de poluição da respectiva sub-região;

b) a cada renovação da Licença de Operação a meta de redução poderá ser revista tendo por base o atingimento da meta anterior;

c) para o cumprimento das metas de reduções de emissões poderá ser utilizado o mecanismo de compensação de emissões por poluente estabelecido no artigo 42-A deste decreto."; (NR)

IV - O artigo 42:

"Artigo 42 - Fontes novas de poluição ou no caso da ampliação das já existentes que pretendam instalar-se ou operar, quanto à localização, serão:

I - proibidas de instalar-se ou de operar quando, a critério da CETESB mediante motivação técnica, houver o risco potencial a que alude o inciso $\mathrm{V}$ do artigo $3^{\circ}$ deste Regulamento, ainda que as emissões provenientes de seu processamento estejam enquadradas nos incisos I, II, III e IV do mesmo artigo;

II - quando localizarem-se em regiões SAT e EVS e aludidas no anexo 11, obrigadas a compensar, conforme estabelecido no artigo 42-A, em 110\% (cento e dez por cento) e $100 \%$ (cem por cento) das emissões atmosféricas a serem adicionadas dos poluentes que causaram os estados, respectivamente, de SAT ou EVS.

Parágrafo único - Para os fins de que trata o inciso II deste artigo, para empreendimentos localizados em municípios pertencentes a mais de uma sub-região, a compensação de emissões poderá ser efetuada entre os empreendimentos situados em qualquer dessas sub-regiões, considerando as exigências previstas para a sub-região." ; (NR)

V - O artigo 42-A, acrescentado ao Regulamento da Lei $n^{\circ}$ 997, de 31 de maio de 1976, pelo Decreto $n^{0} 50.753$, de 28 de abril de 2006:

"Artigo 42-A - A compensação prevista nos artigos 24 e 42 dar-se-á pela geração e utilização de crédito de emissões reduzidas.

$\S 1^{\circ}$ - A geração de crédito, em fontes fixas, dar-se-á mediante a redução de emissões dos poluentes que levaram à saturação, em qualquer grau, da sub-região:

1. em sub-regiões EVS e SAT, para o ozônio, a compensação de emissões dar-se-á por cada categoria de seus precursores, quais sejam, óxidos de nitrogênio (NOx) e compostos orgânicos voláteis (COVs), excluído o metano ( $\mathrm{CH} 4)$;

2. a redução de emissões em fontes fixas deverá ser comprovada por meio de medições efetuadas antes e, com exceção dos casos de desativação de fontes, depois das alterações realizadas;

3. a validação dos resultados de medições realizadas por empreendedores ou por terceiros, fica condicionada ao atendimento dos procedimentos estabelecidos pela CETESB;

4. excepcionalmente, na ausência de procedimentos para medições de emissões, as reduções poderão ser comprovadas mediante utilização de métodos ou fatores de emissões baseados na literatura internacional e reconhecidos pela CETESB.

$\S 2^{\circ}$ - As reduções permanentes de emissão em fontes fixas serão convertidas em créditos aplicando-se o fator de conversão 1,0 para sub-regiões EVS e SAT.

$\S 3^{\circ}$ - A geração do crédito em fontes fixas será efetivada no processo de renovação da Licença de Operação ou do licenciamento das alterações do processo produtivo, bem como por ocasião da desativação de fontes, atendidos os critérios de conversibilidade de reduções de emissões estabelecidos neste artigo:

1. A titularidade do crédito dar-se-á pelo registro, por parte da CETESB, na Licença de Operação, de acordo com o seguinte:

a) constarão da Licença de Operação a data de expiração do crédito, o poluente a que se refere e seu valor em toneladas por ano e em quilos por hora;

b) o crédito refere-se, inicialmente, ao empreendimento gerador da redução das emissões, podendo ser transferido total ou parcialmente entre empreendimentos localizados na mesma subregião.

2. a geração de crédito deverá ser solicitada pelo interessado previamente à implantação das alterações redutoras de emissões.

3. o crédito gerado por fontes fixas terá validade de 10 (dez) anos, extinguindo-se em duas situações:

a) quando da expiração de sua validade;

b) no momento de sua utilização.

$\S 4^{\circ}$ - A compensação de emissões ocorrerá apenas entre fontes localizadas em uma mesma subregião, devendo ser comprovada pelo balanço de massas em toneladas/ano, entre a estimativa da emissão da(s) nova(s) fonte(s) e a emissão registrada no crédito a ser utilizado, sem prejuízo ao inciso I do artigo 42 deste decreto, respeitadas também as seguintes condições:

1. a utilização de créditos por empreendimentos que não detenham sua titularidade depende da anuência do(s) detentor(es) de crédito(s), formalizada em documento que a autorize perante a CETESB;

2. a diferença de cotas (altitude) dos empreendimentos envolvidos na compensação deverá ser inferior a 400 metros.

$\S 5^{\circ}$ - Os créditos gerados por fontes móveis poderão ser efetivados mediante reduções de emissões de poluentes em frotas cativas, que comprovadamente circulem na sub-região onde o crédito será utilizado:

1. a geração de crédito será autorizada somente após a constatação pela CETESB da efetiva implantação das medidas de redução das emissões da frota, respeitada a legislação vigente relativa às emissões de gases, partículas e ruído externo e atendida a capacidade operacional da frota. 
2. entende-se por frota cativa aquela composta por veículos licenciados no Estado de São Paulo e de propriedade de uma única empresa ou entidade de transporte coletivo de passageiros, carga ou outra atividade, caracterizada pela uniformidade da operação, do serviço e área de circulação.

3. a atribuição de fatores de emissão das frotas para fins de cálculo das respectivas reduções de emissão será feita com base nos valores publicados pela CETESB, consideradas também as características tecnológicas das frotas.

4. os créditos serão calculados com base na quilometragem total rodada na sub-região onde o crédito será utilizado.

5. as reduções a que se refere o $\$ 5^{\circ}$ serão convertidas em créditos mediante multiplicação pelos seguintes fatores:

a) 1,0 (um) para substituição da frota existente por veículos novos menos poluentes;

b) 0,9 (nove décimos) para substituição dos motores existentes por motores novos menos poluentes; existentes:

c) 0,8 (oito décimos) para instalação de equipamentos novos de controle de emissões nos veículos

6. a geração de crédito em fontes móveis deverá ser solicitada pelo interessado previamente à implantação das medidas de redução de emissões;

7. o crédito gerado em fontes móveis perderá sua validade se não utilizado em no máximo:

a) 5 (cinco) anos para o caso de substituição da frota por veículos novos, ou de sua motorização por motores novos;

b) 2 (dois) anos para o caso de instalação de equipamentos novos de controle de emissões em veículos existentes;

8. os equipamentos de controle de emissões citados nos incisos anteriores deverão ser certificados por órgãos competentes nacionais ou estrangeiros quanto à sua durabilidade e eficiência na redução das emissões, mediante procedimentos reconhecidos internacionalmente, sendo os testes de certificação realizados com combustível de especificação similar ao comercializado no Brasil;

9. os veículos existentes a serem substituídos para fins de geração de crédito devem ter comprovada sua operação na frota cativa por pelo menos três anos anteriormente à solicitação de geração de crédito;

10. o proprietário ou responsável legal pela frota cativa deverá, após aprovação da proposta técnica pela CETESB, assinar Termo de Compromisso, visando a manter em plena operação os novos veículos, motores ou equipamentos de controle de sua frota por pelo menos 5 (cinco) anos de acordo com as exigências definidas pela CETESB nesse Termo, sujeitando-se pelo seu descumprimento às penalidades previstas neste Regulamento;

11. em caso de necessidade de modificações da frota e/ou de sua operação, durante o período de 5 (cinco) anos, estas devem ser previamente autorizadas pela CETESB, de modo que resultem em reduções de emissões equivalentes ou superiores às previstas no Termo de Compromisso;

12. o Termo de Compromisso deve incluir obrigatoriamente:

a) declaração da quantidade de crédito e o respectivo prazo de validade.

b) a identificação e as especificações técnicas e características tecnológicas de cada veículo pertencente à frota objeto dos créditos e responsabilidade de que essas serão mantidas pelo prazo de 5 anos;

c) a região de operação da frota objeto dos créditos e responsabilidade de manutenção desta pelo prazo de 5 (cinco) anos;

d) as características operacionais da frota objeto dos créditos e responsabilidade de que essas serão mantidas pelo prazo de 5 (cinco) anos;

e) a responsabilidade de que quaisquer modificações na operação da frota, nas características tecnológicas que afetem as emissões, bem como na sua região de operação, só serão realizadas mediante prévia autorização da CETESB;

13. as penalidades por descumprimento às exigências do Termo de Compromisso incidirão individualmente sobre cada veículo em desconformidade autuado pelos agentes credenciados da CETESB;

14. constatada a infração, o agente credenciado da CETESB lavrará o Auto de Infração e Imposição de Penalidade de Multa, contendo a identificação do veículo, o local, hora e data da infração, o ato, fato ou omissão que resultou na infração, a penalidade aplicada e o prazo de no máximo 60 (sessenta) dias para a regularização das desconformidades encontradas, dando ciência ao proprietário ou responsável legal pela frota cativa;

15. o recolhimento das multas aplicadas em decorrência deste dispositivo deverá ser feito em qualquer estabelecimento bancário da Caixa Econômica do Estado de São Paulo - CEESP - através de guia específica a ser definida pela CETESB, consultada a Secretaria de Estado da Fazenda;

16. os veículos objeto da compensação não estão isentos das exigências relacionadas com a emissão de fumaça de que trata o artigo 32 desse decreto;

17. não será renovada a licença de trânsito de veículo em débito de multas impostas por infração às disposições deste decreto."; (NR)

VI - O artigo 42-B, acrescentado ao Regulamento da Lei $n^{\circ}$ 997, de 31 de maio de 1976, pelo Decreto $\mathrm{n}^{0} 50.753$, de 28 de abril de 2006:

"Artigo 42-B - A Companhia de Tecnologia de Saneamento Ambiental - CETESB publicará anualmente as seguintes informações:

I - a partir da classificação do grau de saturação das sub-regiões, metas de redução das emissões; 
II - o inventário das emissões atmosféricas de fontes fixas e móveis, por sub-região e para o Estado de São Paulo, identificando os principais empreendimentos emissores, por poluente;

III - valor e titularidade dos créditos disponíveis nas sub-regiões, com os respectivos prazos de validade."; (NR)

Artigo $2^{\circ}$ - O Anexo 11, acrescido ao Regulamento da Lei no. 997, de 31 de maio de 1976, pelo artigo $7^{\circ}$ do Decreto no. 50.753, de 28 de abril de 2006, passa a vigorar conforme o Anexo que integra o presente decreto. redação:

Artigo $3^{\circ}$ - O artigo $6^{\circ}$ do Decreto $n^{0} 50.753$, de 28 de abril de 2006, passa a vigorar com a seguinte

"Artigo $6^{\circ}$ - Excepcionalmente, para o período entre 28 de abril de 2006 até 31 de dezembro de 2012, vigorarão as seguintes regras para a geração e a utilização dos créditos de emissões mediante o mecanismo de compensação de poluentes:

l) as emissões de precursores de ozônio poderão ser compensadas, com reduções ou créditos gerados em qualquer município do Estado de São Paulo;

II) as emissões de poluentes primários poderão ser compensadas com reduções ou créditos gerados na mesma sub-região ou em quaisquer municípios vizinhos;

III) além dos mecanismos de geração de créditos para as fontes fixas e móveis previstos neste Decreto, serão consideradas, para efeito de geração de créditos de emissão, as medidas que, comprovadamente, resultem na redução de emissão de poluentes para a atmosfera;

IV) a validação dos créditos de emissão a que se refere o inciso III estará condicionada à avaliação da metodologia empregada para o cálculo da redução de emissão e do respectivo fator de conversão de cada medida empregada;

V) entende-se como fator de conversão, o fator de incerteza de cada metodologia de avaliação das reduções de emissões de poluentes;

VI) as reduções comprovadas, ocorridas no período de 3 três anos imediatamente anterior a 28 de abril de 2006, poderão ser convertidas em créditos de emissões, aplicando-se, no caso, o fator redutor de 0,6 (seis décimos).". (NR)

Artigo $4^{\circ}$ - Para o período compreendido entre data de publicação deste decreto até 31 de dezembro de 2012, vigorarão as seguintes regras para o licenciamento ambiental:

I - a ampliação de empreendimentos em regiões SAT e EVS que resultem em acréscimo de emissões acima dos valores aludidos no anexo 11, poderão ser dispensadas da compensação das emissões adicionadas, desde que comprovadamente adotem na sua concepção, instalação e operação, a melhor tecnologia de redução de emissões.

II - a implantação de fontes novas de poluição em regiões SAT que resultem em acréscimo de emissões acima dos valores aludidos no anexo 11 será, em conformidade com o grau de severidade, condicionada a:

a) Saturação: severo

1. utilizar sistemas de controle de poluição do ar baseados na melhor tecnologia prática disponível, tanto para processos produtivos, como para equipamentos de controle propriamente ditos; e

2. compensar, conforme estabelecido no artigo 42-A, em $110 \%$ (cento e dez por cento) as emissões atmosféricas a serem adicionadas dos poluentes que causaram os estados de SAT, até a emissão da respectiva licença de operação.

b) Saturação: sério e moderado

1. utilizar sistemas de controle de poluição do ar baseados na melhor tecnologia prática disponível, tanto para processos produtivos, como para equipamentos de controle propriamente ditos; e

2. compensar, conforme estabelecido no artigo 42-A, em $110 \%$ (cento e dez por cento) as emissões atmosféricas a serem adicionadas dos poluentes que causaram os estados de SAT, até a emissão da primeira renovação da respectiva licença de operação.

III- a implantação de fontes novas de poluição em regiões EVS que resultem em acréscimo de emissões acima dos valores aludidos no anexo 11 será condicionada a:

a) utilizar sistemas de controle de poluição do ar baseados na melhor tecnologia prática disponível, tanto para processos produtivos, como para equipamentos de controle propriamente ditos; e

b) compensar, conforme estabelecido no artigo 42-A, em 100\% (cento por cento) as emissões atmosféricas a serem adicionadas dos poluentes que causaram os estados de EVS, até a emissão da primeira renovação da respectiva licença de operação.

IV - a renovação da Licença de Operação dos empreendimentos localizados em subregiões SAT será condicionada às seguintes exigências técnicas especiais:

a) a utilização de sistemas de controle de poluição do ar baseados na melhor tecnologia prática disponível, tanto para processos produtivos, como para equipamentos de controle propriamente ditos;

b) a implementação de Plano de Monitoramento das Emissões Atmosféricas, segundo Termos de Referência estabelecidos pela CETESB.

Artigo $5^{\circ}$ - Este decreto entra em vigor na data de sua publicação, ficando revogadas as disposições em contrário, em especial os incisos II, III e V do artigo $1^{\circ}$ e o artigo $2^{\circ}$ do Decreto $\mathrm{n}^{\circ} 50.753$, de 28 de abril de 2006.

Palácio dos Bandeirantes, 12 de dezembro de 2007

JOSÉ SERRA 
ANEXO

a que se refere o artigo $2^{\circ}$ do

Decreto $\mathrm{n}^{\circ} 52.469$, de 12 de dezembro de 2007

1. Estão sujeitos ao critério de compensação, os novos empreendimentos e ampliações, cujo total de emissões adicionadas é igual ou superior a:

a) Material Particulado (MP): 100 t/ano

b) Óxidos de Nitrogênio (NOx): 40 t/ano

c) Compostos Orgânicos Voláteis, exceto metano (COVs, não-CH4): 40 t/ano

d) Óxidos de Enxofre (SOx): 250 t/ano

e) Monóxido de Carbono (CO): 100 t/ano

2. Definições

a) emissões: liberação de substâncias para a atmosfera a partir de fontes pontuais ou difusas;

b) óxidos de Enxofre: óxidos de enxofre, expressos em dióxido de enxofre (SO2);

nitrogênio (NO2);

c) óxidos de Nitrogênio: óxido de nitrogênio e dióxido de nitrogênio, expresso em dióxido de

d) Composto Orgânico Volátil (COV) Não- Metano: todo composto orgânico, exceto o metano (CH4), medido por um método de referência ou determinado por procedimentos estabelecidos pela CETESB.

PROC. SMA-339-07 